San Jose State University

SJSU ScholarWorks

1989

\title{
A study of Johann Michael Haydn's church music and a performing analysis of "Run Ye Shepherds to the Light (Lauft, Ihr Hirten Allzugleich)" for a recital perfomance
}

Edward B. von Pohle

San Jose State University

Follow this and additional works at: https://scholarworks.sjsu.edu/etd_theses

\section{Recommended Citation}

Pohle, Edward B. von, "A study of Johann Michael Haydn's church music and a performing analysis of "Run Ye Shepherds to the Light (Lauft, Ihr Hirten Allzugleich)" for a recital perfomance" (1989). Master's Theses. 3233.

DOI: https://doi.org/10.31979/etd.qxf8-ng29

https://scholarworks.sjsu.edu/etd_theses/3233

This Thesis is brought to you for free and open access by the Master's Theses and Graduate Research at SJSU ScholarWorks. It has been accepted for inclusion in Master's Theses by an authorized administrator of SJSU ScholarWorks. For more information, please contact scholarworks@sjsu.edu. 


\section{INFORMATION TO USERS}

The most advanced technology has been used to photograph and reproduce this manuscript from the microfilm master. UMI films the text directly from the original or copy submitted. Thus, some thesis and dissertation copies are in typewriter face, while others may be from any type of computer printer.

The quality of this reproduction is dependeat apon the quallty of the copy submitted. Broken or indistinct print, colored or poor quality illustrations and photographs, print bleedthrough, substandard margins, and improper alignment can adversely affect reproduction.

In the unlikely event that the author did not send UMI a complete manuscript and there are missing pages, these will be noted. Also, if unauthorized copyright material bad to be removed, a note will indicate the deletion.

Oversize materials (e.g., maps, drawings, charts) are reproduced by sectioning the original, beginning at the upper left-hand corner and continuing from left to right in equal sections with small overlaps. Each original is also photographed in one exposure and is included in reduced form at the back of the book.

Photographs included in the original manuscript have been reproduced xerographically in this copy. Higher quality $6^{\prime \prime} \times 9^{\prime \prime}$ black and white photographic prints are available for any photographs or illustrations appearing in this copy for an additional charge. Contact UMI directly to order.

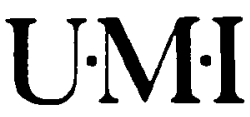

University Microlims International

A Bell \& Howell information Company

300 North Zeeb Road Ann Arbor. MI 48106-1346 LSA

$313761.4700 \quad 800521.0600$ 


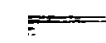


A study of Johann Michael Haydn's church music and a performing analysis of "Run, Ye Shepherds to the Light" ("Lauft, ihr Hirten allzugleich") for a recital performance

von Pohle, Edward Bruce, M.A.

San Jose State University, 1989 


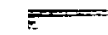




\title{
A STUDY OF JOHANN MICHAEL HAYDN'S CHURCH MUSIC
}

AND A PERFORMING ANALYSIS OF

RUN, YE SHEPHERDS TO THE LIGHT (LAUET, IHR HIRTEN ALLZUGLEICH)

FOR A RECITAL PERFORMANCE

\author{
A Project Report \\ Presented to \\ The Faculty of the Department of Music \\ San Jose State University \\ In Partial Fulfillment \\ of the Requirements for the Degree \\ Master of Arts
}

By

Edward B. von Pohle

December, 1989 
APPROVED FOR THE DEPARTMENT OF MUSIC

Qharlave Achlubeque

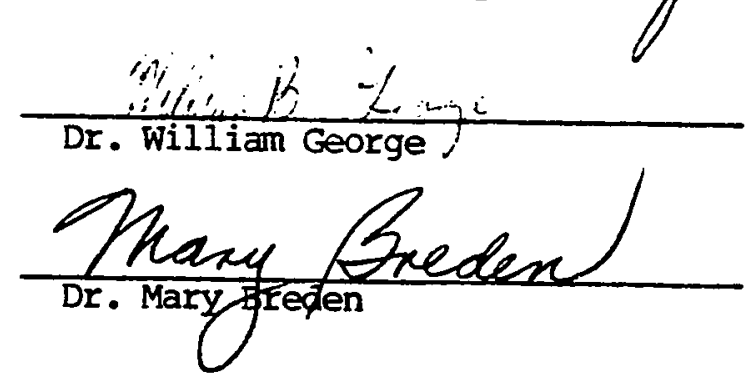

APPROVED FOR THE UNIVERSITY

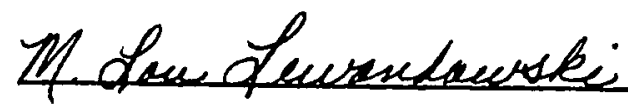

$\mathbf{i i}$ 
ABSTRACT

A STUDY OF JOHANN MICHAEL HAYDN'S CHURCH MUSIC

AND A PERFORMING ANALYSIS OE

RUN, YE SHEPHERDS TO THE LIGHT

(Lauft, Ihr Hirten Allzugleich)

by

Edward B. von Pohle

For 200 years, Johann Michael Haydn (1737-1806) has remained in the shadow of the more renowned classical composers. Highly respected for his compositional skill during his life time, Haydn fell into obscurity along with many musicians when secular concert music superseded sacred music in popularity during the late eighteenth century.

This project report addresses some of the socio-political and cultural conditions which affected Haydn's life and ultimately his music. Though criticized as too old-fashioned and circumspect, Michael Hyadn nevertheless composed many masterful works, which were praised and imitated by Joseph Haydn and Wolfgang Mozart. Much of his church music is liturgically appropriate today.

Haydn's charming and simple Christmas cantata, Run, Ye Shepherds to the Light is examined, and performing suggestions regarding forces required, tempi, phrasing and articulation, and ornamentation are given. 
TABLE OE CONTENTS

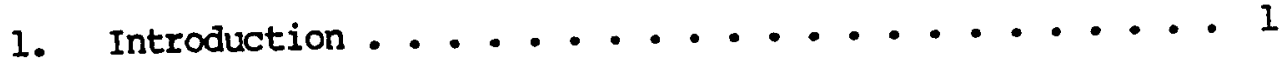

Statement of the Problem ............ 1

Importance of the study ............. 1

2. The Effect of Socio-political and cultural

Conditions in Eighteenth Century Salzburg

on Church Music in the Classical E:a . . . . . . 3

3. Johann Michael Haydn - The Man and His Music . . . . 8

4. Performance Considerations for:

Run, Ye Shepherds to the Light ......... 16

Forces Required ............. 17

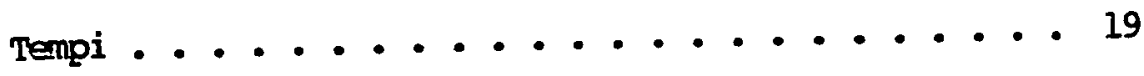

Phrasing and Articulation .......... 23

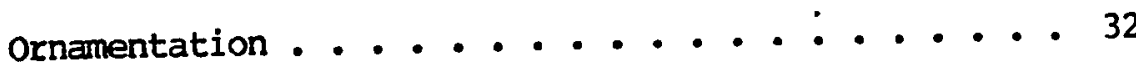

5. Summary and Conclusions ............ $4 \emptyset$

Bibliography ... . . . . . . . . . . . 4 42

Appendix A: Transcription of Run, Ye Shepherds to the Light . . 44

Appendix B: Available editions of Michael Haydin's

church music .............. 93 


\section{CHAPTER 1}

Introduction

Composers have come and gone, each achieving varying degrees of critical acclaim, fortune and fame. Of those who attained greater renown, some did so during their lifetime, while others rose to musical heraldry posthumously. Conversely, many composers earned enviable reputations during their lifetime, only to plumet to virtual obscurity fifty years after their deaths. Johann Michael Haydn was such a composer. Though considered an accomplished composer by his contemporaries, including his friend Wolfgang Amadeus Mozart and his more famous brother, Franz Joseph Haydn, Michael Haydn has been largely ignored for almost 200 years.

The Problem.

In comparison to the advances made by Mozart and Joseph Haydn, particularly in opera and symphonic development, Michael Haydn's contributions may seem less monumental in scope. Nevertheless, his works do represent a high standard of excellence, particularly in sacred music. The purpose of this study is to examine the historical context in which Michael Haydn lived and composed, and in light of that examination, to analyze his sacred composition Run, Ye Shepherds to the Light, (Lauft, Ihr Hirten, Allzugleich).

Importance of the Study.

Most of what is known of Michael Haydn is gleaned from brief 
articles in periodicals or biographical dictionaries. No comprehensive English source is available on him or his works.

Further study is important and relevant not merely because of the quantity of compositions Haydn wrote, but because many of these compositions, specifically the sacred works, are of masterful quality, possessing timeless liturgical appropriateness. Run, Ye Shepherds to the Light is no exception.

When analyzing a musical composition, one must be mindful of the circumstances which affected the composer's life and work. Often factors such as governmental restrictions, ecclesiastical regulations and poor social conditions existed which limited or prevented the expansion, development and innovation of musical style and performance. only after considering a composition in historical context can one objectively assess a composer's-success in accomplishing his desired ends, whether they be creating for entertainment, religious worship or social commentary. Examining a composer's music in historical context also helps give one an understanding which will lead to a more satisfying performance. By providing a brief look at the sociopolitical and cultural climate in late eighteenth century Salzburg, by defining and illustrating elements of Michael Haydn's compositional style, and by analyzing the musical score of Run, Ye Shepherds to the Light, it should become evident that Michael Haydn did indeed produce music that was skillful and worthy of greater study and performance. 


\section{CHAPTER 2}

The Effect of Socio-political and Cultural Conditions in Eighteenth Century Salzburg on Church Music in the Classical period

The Classical period (c. 1756-1825) witnessed developments in music that at times seemed contradictory in purpose. While the seventeenth and early eighteenth centuries gave rise to both instrumental music and opera, it was during the late eighteenth and early nineteenth centuries that these musical avenues were further expanded and developed. The foremost classical composers, Joseph Haydn (1732-1809), Wolfgang Mozart (1756-1791), and Ludwig van Beethoven (1776-1827) were key figures in defining the formal structure of musical composition, specifically the sonata allegro form which reached its apex during this period. In addition, these composers sought to add greater drama and expression to their music. In combining formal structure with dramatic expression, the classical composer met his greatest challenge. Often, he had to

choose between dramatic surprise and formal perfection, between expressivity and elegance: he could rarely have both at once... Haydn and Mozart separately and together, created a style in which a dramatic effect seemed at once surprising and logically motivated, in which the expressive and the elegant could join hands.l

Along with developing and refining the musical forms, classical

\footnotetext{
1

Charles Rosen, The Classical Style. (New York: w. W. Norton and Company, Inc., 1972), p. 44.
} 
composers were also. creating a seeming distinction between music intended for public or professional performances and music meant for amateur performances. Charles Rosen, an authority on classical composers, defines this distinction in terms of instrumental music; however, the comparison applies to vocal music as well. The style of music for public performance, which includes church music, is more formal, more tightly organized and less free than music for amateur performance.

Certain elements of the classical style, greater musical expressivity, a more secular or "operatic" style of vocal writing and expanded use of instruments, created problems in religious music for several reasons.

First of all, "Classic church music was largely Catholic Church music." Historically, the Catholic Church has not encouraged stylistic innovation. Charles Rosen states it is because the church "relies so fundamentally on continuity of tradition." ${ }^{5}$ Percy Young defines the issue:

There was the new demonstrative music of the age on the one hand; the old unyielding liturgy, which demanded, as always, that music should be subordinate to the action and intentions of the

\footnotetext{
2 Rosen, The Classical Style., p. 45. 3

Ibid., p. 366.

4 Reinhard Pauly, Music in the Classic Period. (Englewood Cliffs, N.J.: Prentice-Hall, Inc., 1965), p. 186.

5 Rosen, The Classical style.., p. 366.
} 
form and worship, on the other.6

The often uneasy relationship between art and religion presented further questions. Was music a means for greater celebration and exaltation of the Mass or an agent for more clearly expressing and illustrating its text? If the music is celebrative, then sections such as the penitential "Kyrie" and "Agnus Dei" should be brilliant and imposing. If the music is expressive then these sections should be quiet and pleading. Joseph Haydn's and Wolfgang Mozart's cheery settings of these sections seem to indicate that often classical composers were reticent to yield to the expressive aesthetic in their Mass settings.

The question of what constituted appropriate church music was also unresolved. The clergy considered vocal music more appropriate for church services because of the words. Music historians believe that "in the classical period...choral music was generally thought of as the servant of the church, and only in churches or private chapels could it normally be heard." The hostility of the Catholic Church towards instrumental music in its services manifested itself in restrictions of use by the Austrian Government during the 1780's, a time of great

Percy M. Young, The Choral Tradition. (New York: W. W. Norton and Company, Inc., 1962), p. 157.

\section{7} 8 Ibid., p. 368 .

9 Roger Fiske, "The Viennese Classic Period," in Choral Music. Arthur Jacobs, editor. (Middlesex, England: Penguin Books, Ltd., 1963), p. 164. 
creative activity for Michael Haydn, as well as his brother Joseph, and wolfgang Mozart.

10 (bections of the mass were discouraged. Also, large orchestral ensembles and the use of certain instruments were avoided. Nevertheless, "church music... invariably enjoyed orchestral accompaniment, in spite of papal disapproval." chant to elaborate choral/orchestral settings of the Mass were used in the church services and participation of instruments seemed to be based on the nature and solennity of the occasion. In masses celebrating state occasions and honoring dignitaries, the inclusion of trumpets, horns and drums was not uncommon.

The traditions of the church, fortified by the spiritual, political and financial power of its many institutions and authorities provided a stable and secure, though often frustrating, environment for the function of music. During the 1770's, both Michael Haydn and Wolfgang Mozart were in the employ of Prince-Archbishop Hieromymus count Colloredo of Salzburg who wielded a tremendous influence on composers in the church. Colloredo, a proponent of the Enlightenment, was not a popular figure in Salzburg. His efforts to regulate all facets of $11 \mathrm{fe}$, included reforms in the church services for which he dictated the appropriate length, the kinds of music deemed acceptable, when

10 Rosen, The Classical style., p. 366.

11 Fiske, "The Viennese Classic Period," p. 164. 12 Pauly, Music in the Classic Period., p. 177. 13 op. cit. 
instruments could be employed and under what conditions. For example, the Archbishop did not like the celebration of the Mass to last more than three-quarters of an hour, thus limiting musical contributions to a 15

mere twenty minutes or so. As a result of these restrictions, Mozart was driven to find employment elsewhere. Michael Haydn, too, must have recoiled from Colloredo's unsympathetic personality, for the 1770's (the first years of the Prince-Archbishop's reign) were his least productive 16 years.

As a result of reforms encouraged by Emperor Joseph II, the number of worship services was reduced. Those which remained were significantly shortened and simplified. Less money was available to pay church musisians; subsequently, the dedicated, professional church musician all but disappeared in the late eighteenth century. The more lucrative and popular operatic and symphonic forms were drawing the best efforts of the major composers. The composers who stayed in the church's employ, unless holding a major post, were forced to accept various other duties or teach to supplement their income. This was the experience of Michael Haydn.

14

Charles H. Sherman, editor. Foreword of Johann Michael Haydn's Missa Sancti Hieronymi. (Columbia, MO: University of Missouri Press, 1976).

15 16

Fiske, "The Viennese Classic Period," p. 177.

Sherman, Foreword of Missa Sancti Hieronymi. 17

Elwyn A. Wienandt. Choral Music of the Church. (New York: The Free Press, 1965), p. 218. 


\section{CHAPTER 3}

Johann Michael Haydn - The Man and His Music

Johann Michael Haydn was baptized on September 14, 1737 in Rohrau, in lower Austria. Like his older brother, Joseph, Michael became a choirboy at St. Stephen's Cathedral in Vienna. Prominent at St. Stephens, the st. Cecilian Brotherhood, a Jesuit order, was vital in training many of Vienna's and Austria's finest musicians. Their conservative trends left an impact on young Michael.

Michael is said to have possessed an unusually clear and beautiful voice with a range of three octaves. "Once, his singing so pleased Emperor Joseph that he awarded Haydn fifty goldpieces. Michael, like a good boy, gave half the sum to his peasant parents and the other half to Kapellmeister Johann Georg von Reutter, Jr. [(1708-1772)] to hold for him against his 'retirement.' He never saw a penny of it again."

Besides singing, the choir school curriculum at st. Stephen's included keyboard and violin, as well as other subjects. Michael was also an excelient organist. As a student, he acted as assistant organist at the choir school. Haydn is also credited with organizing a society among his fellow choristers for detecting plagiarism in composition.

In 1757, at seventeen, Michael left St. Stephen's to become

Bruce C. Mac Intyre. The Viennese Concerted Mass of the Early Classic Period. (Ann Arbor, MI: UMI Research Press, 1986), PP. 16, 17. 19

David Mason Greene. Greene's Biographical Encyclopedia of Composers. (Garden City, NY: Doubleday \& Company, Inc., 1985), p. 408. 
Kapellmeister to Count Firmian, Bishop of Grosswardein in hungary. Meanwhile, his brother Joseph, still poor and unknown, was working as $\underset{2 \theta}{\operatorname{acc} m p a n i s t}$ and valet to the ill-tempered singing teacher vicolo Porpora.

Five years later, in 1762, Michael was offered and accepted the position of court musician and concert master to Fimian's uncle, Archbishop Sigismund Schrattenbach of Salzburg; thus he held an important position in Salzburg during Mozart's time there (1756 - 1781) .

Haydn married Maria Magdalena Lipp, daughter of the court organist, Eranz Ignaz Lipp. A singer in the Archbishop's court, Magdalena was highly praised for her talent. Mozart, himself, cast her in the title role of his opera, La Einta Semplice.

The Haydn's only child, Aloysia Josepha, was born in 1770 , but died within a year,. plunging Michael into a gloon that never really lifted. Magdalena was so devastated that she took to wearing a hair shirt and subjected herself to regular self-administered beatings.

The death of his child was shortly followed by the death of Haydn's friend and patron, the Archbishop Sigismund in 1771. It was in his honor that Haydn composed his best-known work, the Requiem in C Minor.

Opon the death of his colleague and sometime collaborator, Anton Cajetan Adlgasser (b. 1729) in 1777, Hayan became organist of the churches of the Trinity and St. Peter's Monastery in Salzburg. When the

\section{0}

Alec Robertson. Requiem: Music of Mourning and Consolation. (London: Cassell \& Company, Ltd., 1967), p. 66. 21 Greene, Greene's Biographical Encyclopedia of Composers:', p. 468. demands and strictures imposed by Sigismund's successor, Archbishop 
Colloredo caused Mozart to leave Salzburg in 1781, Haydn succeeded him as court and cathedral organist, posts he held until his death on March 31, 1806. Haydn was buried in a side chapel of St. Peter's Cathedral where, in 1821, friends erected a memorial in his menory.

Though certainly exposed to the basics of musical composition at st. Stephen's, Haydin was, to a considerable extent a self-taught composer. He studied the works of Johann Joseph Fux (1660-1741) and was particularly influenced by Fux's treatise on counterpoint, "Gradus ad Parnassum."

Haydn composed a large quantity of music. According to modern standards, some of his compositions are considered old-fashioned while some sound undeniably fine to modern ears. Although he composed works in virtually every genre required by the imsical practice of the daythat is opera, oratorio, over 40 symphonies, a considerable amount of occasional music, chamber works and partsongs--he is best known for his over 400 sacred compositions. In his sacred music, Haydn's talents found their fullest expression. Michael Haydn was regarded by his contemporaries as a superlative master of the church style. No less a critic than Joseph Haydn declared his brother's Masses to be finer than 22 his own.

The German writer and musician, Ernst Theodor amadeus (E.T.A.) Hoffman (1776-1822) who had a profound influence on literature and music, praised Michael Haydn's sacred music. In a series of essays on

\footnotetext{
22

Charles H. Sherman, editor. Preface to Johann Michael Haydn's Missa Hispanica. (Salzburg: Haydn-Mozart Press, 1966).
} 
church music, he compared the sacred works of Joseph Haydn and Mozart with the works of Michael Haydn. Hoffman believed Joseph Haydn's and Mozart's sacred compositions were contaminated by excessive sweetness which banned all seriousness and dignity, whereas the works of Michael Haydn, he felt possessed the necessary serious tone. Hoffman also thought Michael's sacred works surpassed those of his brother.

Perhaps one reason that Michael Haydn's works were considered superior among his contemporaries, was because of their consistent appropriateness for standard liturgical use. Whereas Mozart's and Joseph Haydn's church works were primarily works written for state occasions or in honor of particular individuals, Michael Haydn's were written for regular worship services. Though he often utilized elements of the older style, Haydn also incorporated newer musical trends. His music neither lacks sophistication nor shows an absence of skill. Homer ulrich contends that Haydn amalgamated various styles by bringing to "his masses a mixture of plainsong, modal writing and the use of cantus firmi," superimposing "these elements on a mid-eighteenth century harmonic background." Haydn also wrote Masses that were thoroughly "in the style of their time, with no echoes of Renaissance or Baroque style."

Always aware of the function of his church music, Haydn's concern

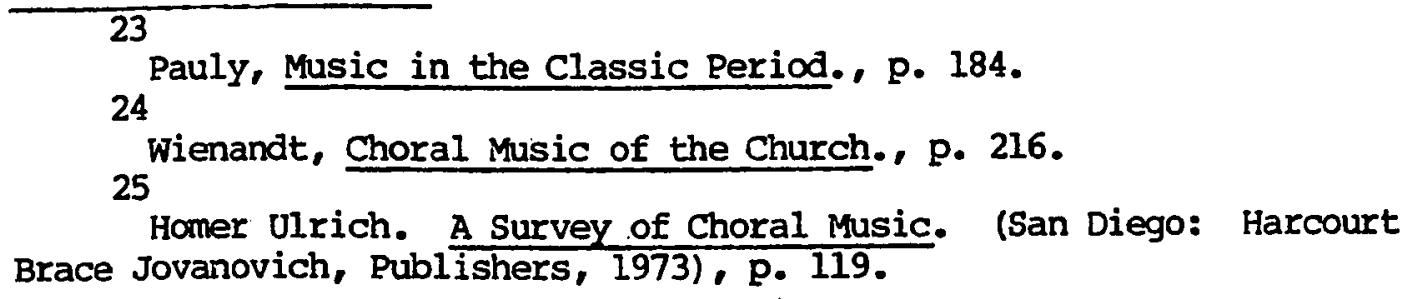


for liturgical propriety won him the approval of the nineteenth century Caecilian reformers who strove to supplant tawdry and often pompous church music with a more decorous and liturgical style. This same concern, however, also caused him to be labeled a purist by same later critics.

In the Missa a due cori or Missa Hispanica (first performed by Haydn on June 24, 1792), Haydn's masterful use of both drama and restraint is clearly manifested. For example, in contrast to the "secular" virtuosic and operatic solo movements employed by his contemporaries, Haydn incorporated more fitting, extended coloratura passages as interpolations within essentially choral movements. This pleased both musicians and clergy, while delighting the congregation who loved to hear his lyrical solo writing. For the premiere of the Missa a due cori, Haydn added drama by employing the forces of over sixty musicians stationed in three choirlofts. The performance was so well received that a special collection was taken up to help with the expenses.

Perhaps the most significant of Haydn's sacred compositions is the Requien Mass, Missa pro defuncto Archiepiscopo sigismundo or Missa pro defunctis. Impelled by the death of his employer Sigismund Count Schrattenbach Prince-Archbishop of Salzburg, a connoisseur and liberal patron of music, Haydn set out at once to compose a work in his honor. Working at feverish speed, he completed the work in two weeks time on December 31, 1771. Charles H. Sherman, an authority on the life

Sheman, Preface to Missa Hispanica. 
and music of Michael Haydn, asserts that "the Requiem clearly proclaims Haydn's genius," establishing his right to be counted among the finest composers of his time. 27

In his book, Requiem: Music of Mourning and Consolation, Alec Robertson states that Haydn's requiem possesses a good sense of " form with recurring themes. He suggests that the orchestral accompanying figures perhaps lack inventiveness, but he praises Haydn's choice of setting the "Dies Irae" portion in one movement. Haydn's "Dies Irae," he declares, is "an extremely well-integrated setting of the sequence, and in point of form, it is much to be preferred to the breaking up of the poem into distinct settings." ${ }^{28}$ Lacking in the sentimentality which sometimes prevailed in similar works during the late eighteenth century, Haydn's Requiem was appreciated for its seriousness of tone and dignity of expression. It is obvious that Mozart was impressed with Hayan's Missa de profunctis, since Mozart's requiem, composed some 20 years later, corresponds in a remarkable number of details. Similarities can be seen in the Introit (Requiem), Sequence (Dies Irae) and offertory (Domini Jesu Christu). It was Michael Haydn's Missa de profunctis that was used at the funeral of his brother, Joseph.

Haydn sought to write music that appealed to the common person as well as to the aristocrat. He illustrated this by "popularizing" the mass, composing several in the German vernacular rather than Latin. In doing so, he retained the liturgical propriety while making it

\footnotetext{
27 Sherman, Foreword of Missa de profunctis. 28 Robertson, Requiem: Music of Mourning., p. 61.
} 
understandable to the uneducated.29

Haydn's motets exhibit the same blending of old and new styles as noted in his longer sacred works. He composed both unaccompanied and orchestrally supported motets. Some are simple colla parte settings, in which instruments merely double the vocal lines, while others are more complex works with elaborate instrumental introductions and interludes between solo and choral sections. of the over one hundred works he wrote for Archbishop Colloredo, most are graduals. Though harmonically simple and primarily homophonic, these pieces have lovely, easily singable melodic lines and employ various textures and accompanimental devices. Ein -lob und Danklied "O grosser Gott, dich loben wir" is written for four-part men's chorus, mixed chorus and treble chorus with orchestral accompaniment. Others such as the "Prope est Dominus," and the "Hier liegt vor deiner Majestat" are for chorus and trio sonata (employing strings and continuo, and horns and continuo, respectively). Additional works are scored for strings and winds combined. (For a list of available editions of Michael Haydn's church music, see Appendix B.)

simplicity is a primary characteristic of much of Haydn's music. The combination of plain utterance with folk-like melodies in his liturgical works charmed late eighteenth century Austrians. A good example of Haydn's application of simple melodies, uncomplex harmonic

Young, The Choral Tradition., p. 215.

Wienandt, Choral Music of the Church., p. 332. 31

Ibid.. p. 331 . 
progressions and uncomplicated accompanimental devices is the Christmas cantata, Run Ye Shepherds to the Light (Lauft, ihr Hirten, allzugleich). 


\section{CHAPISTR 4}

\section{Performance Considerations for:}

\section{Run Ye Shepherds to the Light}

In the Gospel of Luke, the nativity scene in Bethlehem is framed by several marginal events which by their very nature have impressed themselves upon the hearts and minds of the camon people for centuries. The fact that the angel first announced the news of the Christ child to the lowly shepherds and that they were allowed to be the first to see and honor their Lord is a great distinction. These events have been inseparably linked with the celebrations and festivities of Christmas.

A childlike devotion and modest faith leave their imprint on the countless shepherd songs of Austria. For this pastoral cantata, Michael Haydn used just such an uncomplicated text, devoid of all academic device. The music itself, also bears the strong mark of popular elements: simple melodies, contrasts in mood, trio sonata accompaniment, and solo voice writing.

The cantata is set in four relatively short movements. The first movement, a chorus, has an instrumental introduction which sets the style of the cantata. The chorus is in three parts. The first theme beginning in B-flat major with a modulation into the dominant ( $F$ major) is followed by a surprising passage in the minor (first $\mathrm{F}$ minor then $\mathrm{C}$ minor). There is a reprise of the first theme in the original key. The second movement in E-flat major is an extended coloratura aria for soprano representing the voice of the angel. The aria is followed by a 
brief recitative which leads directly into the last movement and back to the key of B-flat major.

The fourth movement is a bucolic lullaby complete with rocking motifs in the strings and voices. It is interrupted several times by more rugged themes reminiscent of the opening movement, then returns to the rocking lullaby motifs. It ends dramatically with a very quiet and unaccompanied "sleep, sleep" on the final cadence.

For analyzing and performing this work, an German/English edition has been provided (See Appendix A), based on an urtext, transcribed by Rudolf Ewerhart and published in a collection of sacred works, entitled Polyphonia Sacra (Laaber-Verlag, Laaber, 1985). This urtext is based on the original manuscript found in the Benedictine Abbey at Rremsmunster, Austria. The following musical illustrations are taken from this urtext. Also currently available is an English edition, edited by Elwood Jay Johnson,. published by Coronet Press. Some textual changes are based on this edition.

\section{Forces Required}

The cantata is set for SATB choir, soprano soloist, violin I and II, and continuo, and with the possible exception of the soprano aria, is easily within the grasp of the average church choir or high school choir. Haydn's choice of simpler, quainter settings made his music accessible to his students and to the available church musicians. The better musicians in Haydn's time were often seeking more lucrative careers provided by public concert and opera, and were usually employed by the church only for lavish festival services. 
When choosing the number of singers and players for performing this cantata, one must consider the questions posed by authorities, such as Joshua Rifkin and Robert Marshall. These two musicologists have written numerous articles for the periodicals High Fidelity and Musical Times, debating whether or not small choirs should still be used in the performance of seventeenth and late eighteenth century sacred music since that is all composers such as J. S. Bach, Wolfgang Mozart and Michael Haydn had available. Other considerations in choosing the number of performers should include clarity of sound desired, textural contrasts, dynamic demands and the relationship of voices to instruments.

The transparent hamonies and uncomplicated textures in Run, Ye Shepherds to the Light suggest relatively light choral forces. The composition could be performed adequately with as few as 3 to 4 singers per part or increased to as many as 10 to 12 on a part. Something halfway in between, say 6 to 8 , is this author's suggestion.

The instrumental accompaniment is written for trio sonata--two solo violins and continuo. The keyboard can be doubled by either cello, string bass, bassoon or viola da gamba. Because this piece is intended for church use, the natural choice for keyboard instrument would be organ; however, it would not be unstylistic to use a harpsichord or piano forte. If an organ or harpsichord is not available, a modern piano could be used for a satisfactory performance, providing the conductor and keyboardist work to achieve dynamic balance and proper articulation.

When this work is performed by a larger chorus, additional strings 
might we needed. Using three strings per part is preferable to two for better blending and tuning. Two tend to oppose one another. Also, a string bass could be used in addition to cello for added depth. Balance between singers and accompaniment is crucial and acoustical settings are always an issue in detemining the size of the instrumental ensemble. According to Thurston Dart, an authority on performance practice, it was not unusual in the eighteenth century to add or substitute winds in most instrumental ensembles. Having no specific parts written out for flutes and oboes doesn't mean they were not employed. Often, winds doubled the strings for the sake of texture and tonal color. In this composition, flutes could be substituted for or added to the violin parts, depending on the size and strength of the chorus. Considering the pastoral nature of the first movement, the flute provides a descriptive element resembling the shepherd's pipe. Dart does suggest that "whenever one or more wind instruments are used the bass-line should be strengthened by a bassoon."

Tempi

This shoice of tempo, more than any other single factor can make the difference between a performance that is musically alive and captivating and one that is dull, lifeless and stylistically inappropriate. For many years performances of eighteenth and early nineteenth century music reflected the musical tastes of the late romantics. Chosen tempi were

32

Thurston Dart. The Interpretation of Music. (New York: Harper and Row, Publishers, 1963), Pp. 69, 70. 
often extreme; both fast and slow. Early twentieth century editions of eighteenth and nineteenth century compositions provide tempo and metronome markings which many conductors accept without question. However, recent musicologists have further studied the musical practices of the eighteenth and early nineteenth centuries and discovered that many musicians and aestheticians during this era (J. J. Quantz, 16971773; C. P. E. Bach, 1714-1788; Leopold Mozart, 1719-1787, to name a few) gave specific descriptions for interpreting the suggested tempi and mood markings, as well as the relationship between the two.

Baroque composers and early classical composers were brief in their indications on tempo. Usually one word, such as allegro, vivace, adagio, etc., sufficed, because tempo markings were more or less universally accepted and understood. To modern performers, these markings aren't always clear.

The very live acoustical properties of many churches and cathedrals require that certain brisk tempi be regulated so as not to create a blurring of diction and articulation. Modern halls and churches with acoustical damping would require faster tempi.

In a choral composition, the mood established by the text is a najor consideration. In Haydn's cantata, the pastoral instrumental introduction creates a feeling of anticipation and excitement. The text further establishes the mood:

Run, ye shepherds, to the light, New tidings do I carry. Joy fills all the starry night. Come with me, do not tarry.

In lowly manger bare, Come see the infant there; 
A Child, the King of Glory. With all your might, Run quickly toward the light, The star of ancient story.

This is no calm scene of shepherds strolling languidly among their sheep. The musical setting reflects the animation of the episode. The tempo marking is presto, meaning very quick. The question is, just how quick? Perhaps the answer lies in the string parts.

The bass line consists of moving eighth note figures with occasional sixteenth note runs which help to establish the rhythmic tempo. This passage should sound animated but not frantic:

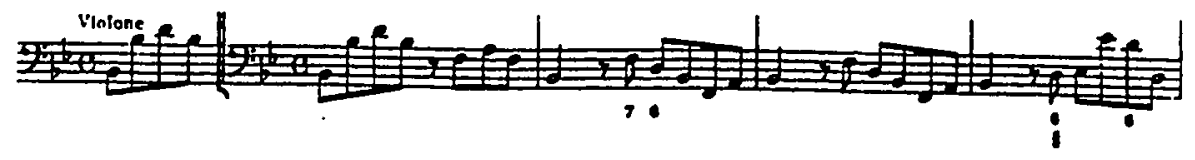

The upper strings reinforce the tempo with a complenentary eighth note melodic pattern:

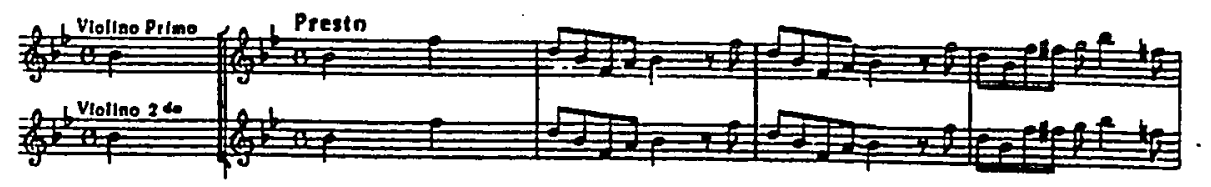

The brisk sixteenth note accompanimental figures in the violin parts in measures 17-26 and 34-36 (See Appendix A) add energy to the vocal lines. In light of the aforementioned factors, a metronome setting of 120 to 132 per quarter-note is suggested.

The second movement is a solo aria in $2 / 4$ meter marked andante. According to the Harvard Dictionary of Music, andante indicates a moderate "walking" speed. There is no universal agreement as to whether 
andante belongs to the quick or the slow tempi; however, many conductors think of it as much slower than is musically wise. Eva and Paul BaduraSkoda, authorities on the performance of classical music, attest that "in Mozart's time, 'andante' was not really a slow tempo-that was a nineteenth century development. For Mozart, it was a fairly flowing tempo, still in accordance with the original meaning of the word 'moving'." ${ }^{33}$ Haydn would have adhered to the same principal.

The joyful spirit of the news of the Messiah, ecstatically proclaimed by the angel to the shepherds, creates a very bright and cheerful mood. The coloratura aria with its light, buoyant character and many lengthy ornamental patterns requires a quick tempo. For conducting the $2 / 4$ meter, a two-beat pattern is obviously best in order to attain a nice flowing lilt; however, a four-beat pattern might be required for inexperienced players. A suggested metroname marking is 58 to the quarter-note. .

The short recitative requires no special mention except. that it should be conducted cleanly and should not drag. This brief declaration should not become declamatory.

The last movement, consisting of lullaby motifs is marked allegro, suggesting a quick and lively tempo. This seemingly contradictory marking to the usual tempo for lullabies indicates that the composer did not want this section slow. The prominence of vocal homophony in this movement should preclude setting too slow a tempo. Although the

33

Eva and Paul Badura-Skoda. Interpreting Mozart on the Keyboard. (London: Barrie and Rockliff, 1962), p. 29. 
mood is one of tranquility and rest, it shouldn't be so drawn out as to put the audience to sleep. There should be a feeling of line even in the most extended lyrical phrases.

The 3/4 meter could be conducted with either a fairly quick threebeat pattern or a rather slow one-beat. If conducted in three, the conductor must keep his beats small and fluid. If done in one, he must be careful not to land heavily on the downbeat, causing unnatural accents on each first beat. A metronome marking of approximately 112 for the quarter-note advisable.

\section{Phrasing and Articulation}

Phrasing is to music what punctuation is to language. Whereas punctuation groups words into units to form clear ideas, phrasing groups notes and motifs together to make musical sense. In language and music alike, to phrase is to breathe. Incorrect phrasing can distort the meaning of a sentence or that of a musical line.

The short, pericdic, articulated phrase was the clearest character35 .

istic in the formation of the classical style. Haydn used this style of phrasing in his cantata. The choruses contain short vocal phrases with frequent sequencing. Very few phrases are more than a measure or two, with the exception of those in the solo aria. Text underlay in the choruses usually determines vocal phrasing; however, in the solo aria, phrasing requires more thought due to the extended melismas or vocal

\footnotetext{
34 Hermann Keller. Phrasing and Articulation. (New York: W. W. Norton and Company, Inc., 1965), p. 4.

35 Rosen, The Classical Style.. p. 57.
} 
runs. In the string parts, the breaks in melodic phrases are often indicated by rests and by sequencing.

Articulation is defined as "the characteristics of attack and decay of single tones or groups of tones and the means by which these characteristics are produced." ${ }^{36}$ It differs from phrasing in that it binds together or separates individual notes rather than groups of notes. Articulation can be thought of as the diction of music, distinct, clear execution of tones and motifs. The use of proper vocal and instrumental articulation correlates with the choice of tempi in creating performances that are exciting, vital and stylistically distinctive. As with tempo, modern approaches to articulation often reflect romantic influences so that the lightness and clarity of baroque and classical music is lost in ponderous and overly legato performances. Successful interpretation of a musical line, achieved through articulation, is the result of the performer creating space or separation between notes which are audible to the listener. This means rendering the appropriate varieties of separation from legato, in which no distinct articulation of the notes is used, and staccato, in which the note is shortened by varying degrees depending upon the requirements of the music. There is significant debate regarding the articulation of the median sense, or non-legato, as it called. In the baroque period,

\footnotetext{
36

Harvard Concise Dictionary of Music. Don Michael Randel, editor. (Cambridge, MA: The Belknap Press, 1978), p. 27. 37

Frederick Dorian. The History of Musical Performance. (Ned York: W. W. Norton and Company, Inc., 1942), p. 160.
} 
the

\begin{abstract}
conception of an average articulation.... is neither joined quite smoothly nor separated very sharply; it is somewhere in the middle between the two extremes. This is a principle which, however liable to exceptions, deserves our most respectful attention whenever the passage is neither cantabile nor energetic, but is indeed average and ordinary. 38
\end{abstract}

C. P. E. Bach and Leopold Mozart both suggest that the non-legato style was the correct way to articulate in performing the music of their time. On the other hand, late classical composers such as Muzio Clementi (1752-1832) and Carl Czerny (1791-1857) instructed players to hold the FULL LENGTH of every note perhaps to combat the prevalent habit of overshortening. The majority of evidence, however, indicates that from the late seventeenth century to the turn of the nineteenth century, the non-legato or detache style of playing was used unless otherwise indicated. Detache is as necessary for choral singing as it is for instrumental playing.

Articulation is influenced by factors such as intervals, rhythm, pitch, and tempo. For example, even rhythms generally indicate a more legato articulation, uneven rhythms, staccato. Also, slow pieces are generally performed in a heavy, expressive manner, whereas fast pieces are more lightly articulated.

Often it is difficult to interpret the signs of articulation, particularly slurs and dots. In some instances, slurs indicate

38

Robert Donington. Barogue Music: Style and Performance.

(New York: W. W. Norton \& Company, 1982), p. 31. 
phrasing, but in others, articulation. In general, phrasing slurs are used over a longer section, are used in cantabile (singing or lyrical) themes and often end at the barline. Articulation slurs are always short and frequently appear with staccato dots or strokes. Dots alone are used to shorten the value of the note, creating more space between notes.

In Haydin's cantata, the text, the texture, and the tempo and articulation markings in each movement influence the conductor's ability to successfully develop the musical line, create proper phrasing, and apply artistic nuance.

In the first movenent, the strings establisin the mood. For the most part, the cello/bass line is played detached with phrasing provided by rests or as agreed upon by conductor and player. The violins introduce a theme that is later picked up by the sopranos. In order to produce the brightness and clarity required of the musical phrase, the first two half-notes should be played downbow with a full bow. This will help create a rich tone that is separated by a brief articulatory silence illustrating the punctuation between "run" and "ye" of the first phrase. This bowing should be used throughout.

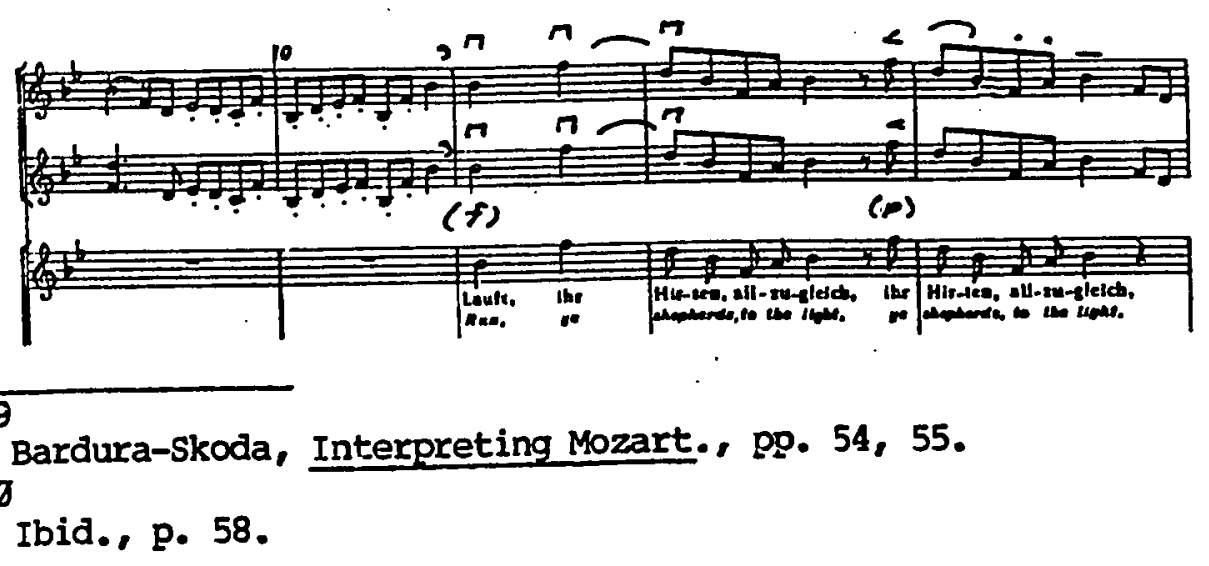


The slurs used in the first violin part starting in measures $6-9$ indicate that the quarter-note should be given a slight accent with no separation between it and the following eighth-note. It was common to define. "good" notes and "bad" notes as those appearing on strong beats ( 1 and 3 ) and weak beats (2 and 4). These slurs illustrate this emphasis on "good" notes.

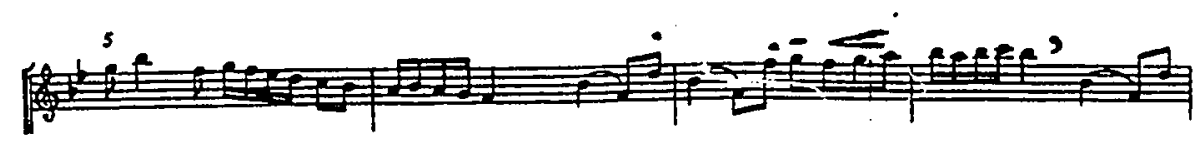

The staccato markings used in measures $9-10,41$ and $59-60$ are expressive of the sound of the shepherds running away. The articulation should be light and detached, with a slight diminuendo.

The text is generally articulated as punctuated. Care has been taken to match English phrasing with that of the German. For the sake of tone quality and natural accentuation, the quarter-notes in measures 14 and 15 (See Appendix A) need to be stretched. Singers need to be encouraged to keep the vowel open rather than singing on the " $n$ " of "run." This method will prevent cutting off the tone and help produce the desired messa di voce or bell-effect created by early bows and church acoustics.

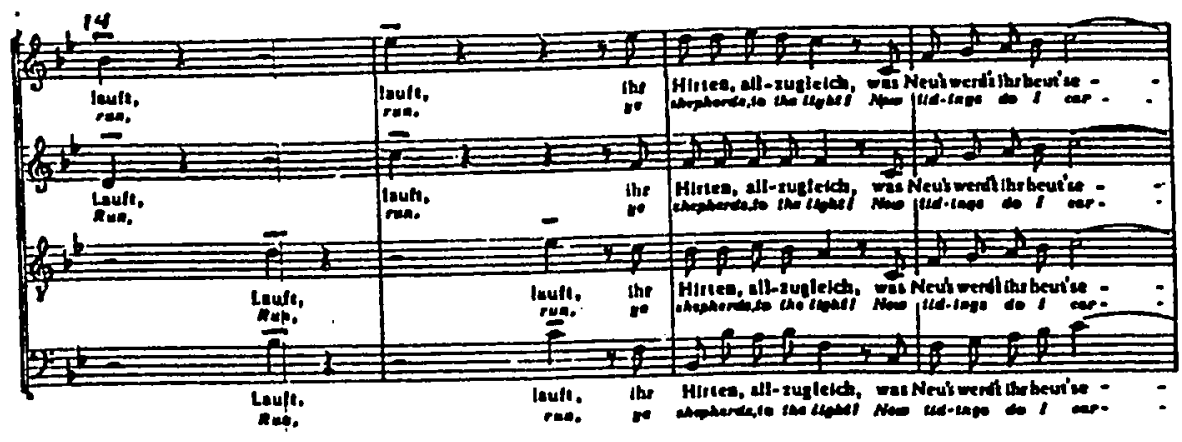

A sudden mood change occurs in measure 32 from the quiet intensity 
of the duet to the sudden broad climax when all voices join. The rapid sixteenth-note figures in the upper strings which begin piano and grow to forte enhance the change in mood. Lighter, detached articulation is indicated at the beginning of the phrase with more full-voiced punctuated articulation required toward the end of the phrase.
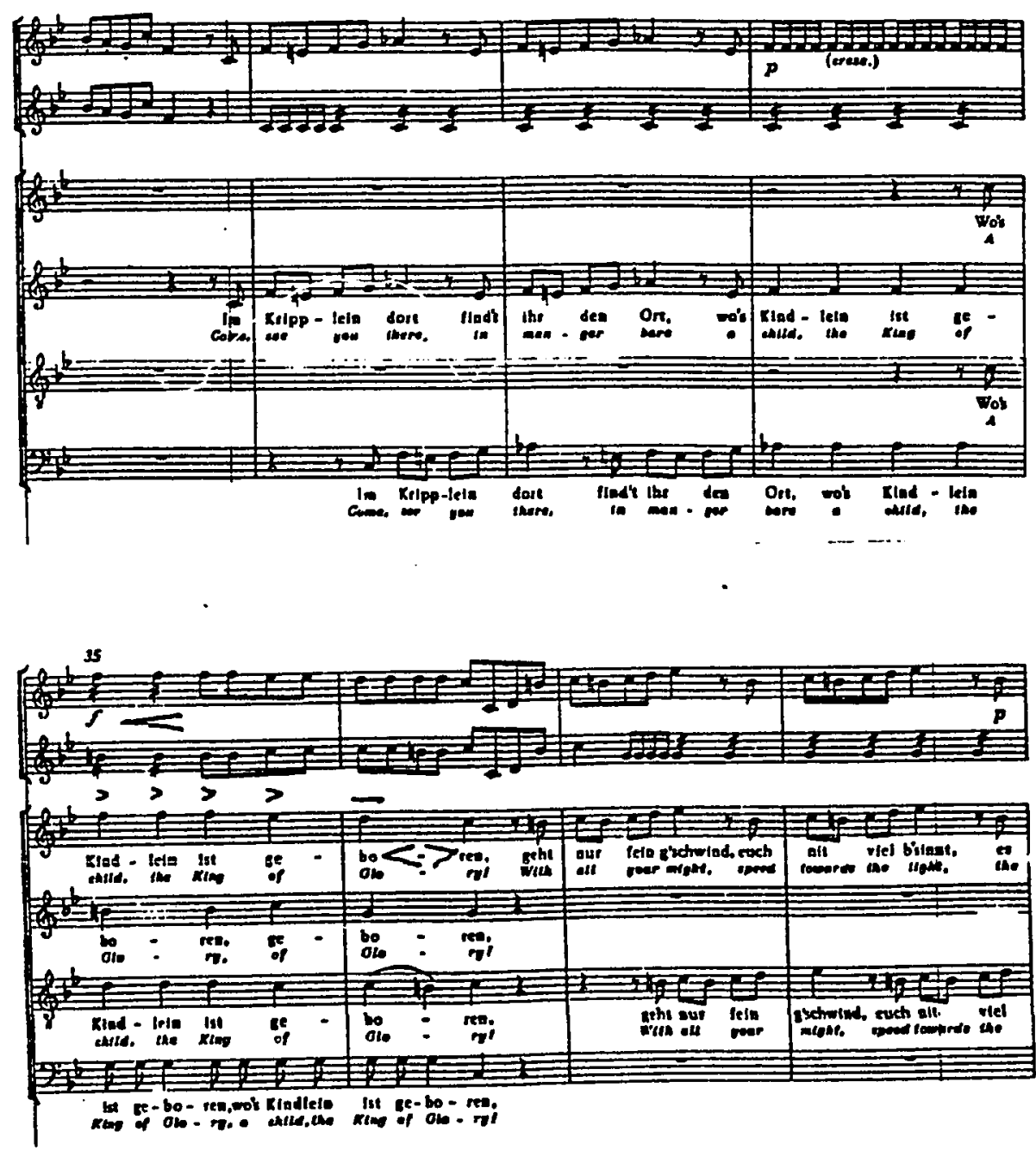
The keyboardist's role is to continue in the established style as prescribed by Robert Donington in his book, Baroque Music: Style and Performance, where he cites Friedrich wilhelm Marpurg. For playing, one should employ

the ordinary movement which consists in lifting the finger from the last key shortly before touching the next note. This ordinary movement, which is always understood is never indicated.41

It should be remembered that this piece reflects the excited and energetic state of the shepherds. All musicians whether singing or playing need to be aware of mood throughout.

In the second movement, the cello/bass part should be played lightly and detached. The violins have a prominent duple pattern of sixteenth-notes. The slur marikings imply that there should be two sixteenth-notes to a bow. This means of articulating will help keep the passage smooth and lilting at the brisk tempo.

The soprano soloist should strive to maintain the light and vibrant mood established by the strings in the introduction. In the urtext translation, there is natural articulation provided for by agogic accents or accents on longer notes. In measure 88 , the first syllable in "happy" (retranslated in Appendix A as "blessed") is sung on a dotted eighth note which provides a slight accent on this key word.

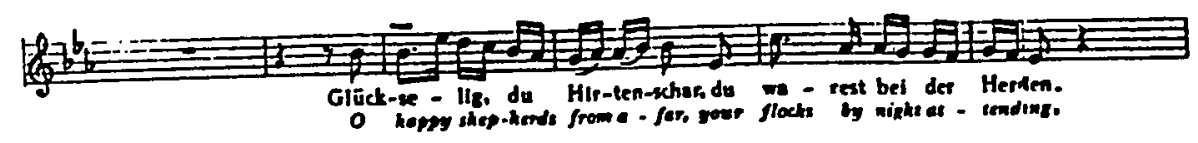

41 Wilheln Friedrich Marpurg, "Anleitung zum Clavierspielen," as cited in Robert Donington's Baroque Music: Style and Performance. (New York: W. W. Norton \& Co., 1982), p.30. 
As in the previous movement, the keyboardist maintains the light detached articulation which, like the strings, creates the buoyant and lilting foundation for this chaming lyrical aria.

The short recitative which makes up the third section is for soprano soloist accompanied by continuo. The main function of the accompaniment is to provide a clear harmonic progression to support the recitation. Whole-notes were separated in order to highlight these progressions. Additionally, the cello/bass should clarify hamonic changes by creating more space between the quarter-note upbeats and the following half-notes or whole-note by changing bows.
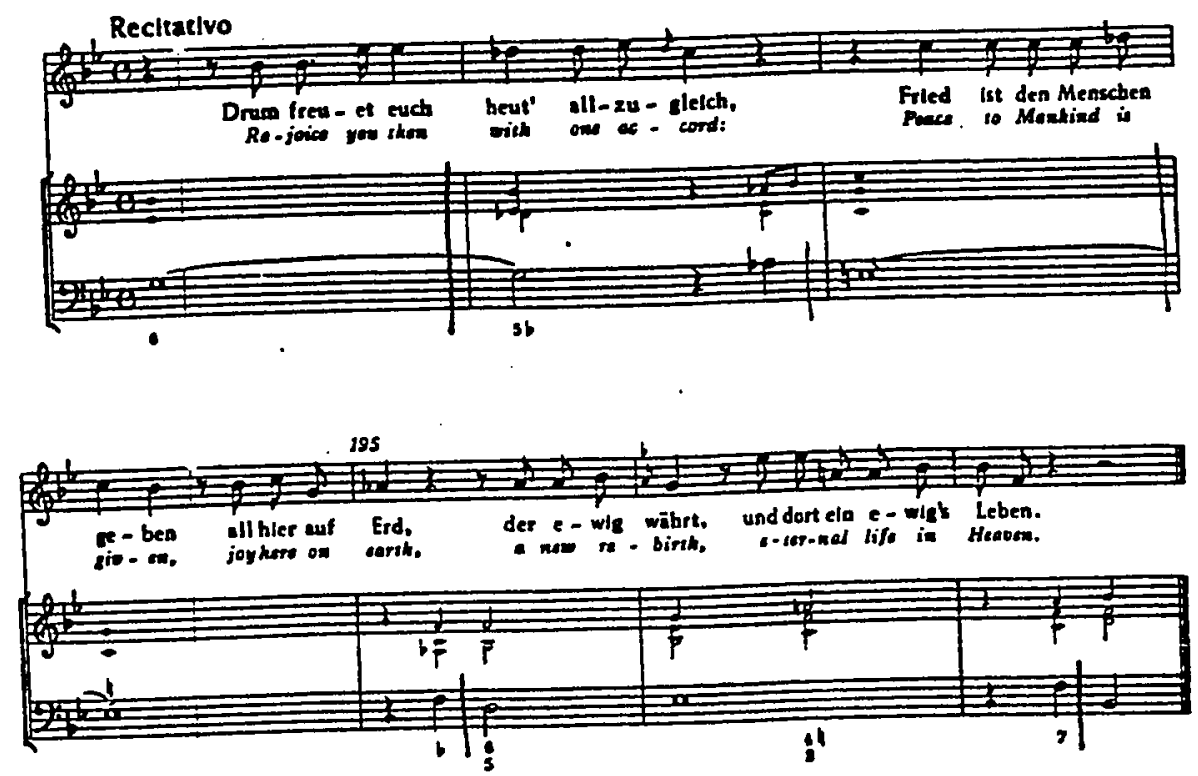

The keyboardist should separate each chord, being sure to sound the changing chord precisely on the beat for added emphasis on the syncopated rhythms. The conductor should be subtle but very clear in beating the pattern.

Because of the lyrical, lullaby nature of the last movement, there might be a tendency for the inexperienced musician to perform it very 
legato. This is a mistake. Natural rhythmic and agogic accents provide opportunity to phrase and articulate. For example, in the first violin part, a slight break after the first eighth-note in measure 199 gives a lift to the next phrase.

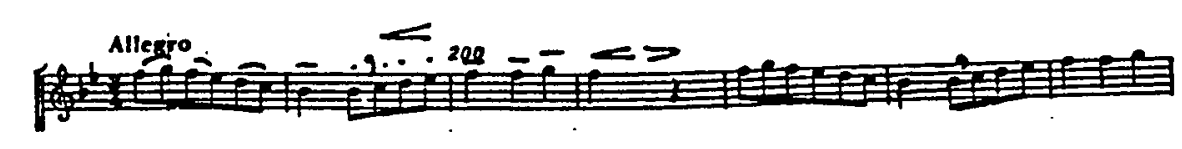

Also, phrasing and articulation, though brief, should be employed in measures $250 f$ to avoid what could be a monotonous succession of eighth notes.

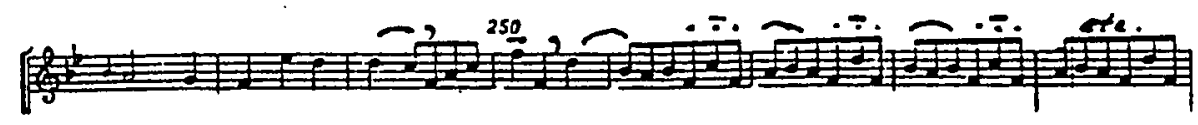

In the vocal parts, the text helps the conductor determine much of the phrasing. punctuation often illuminates natural places for lifts.

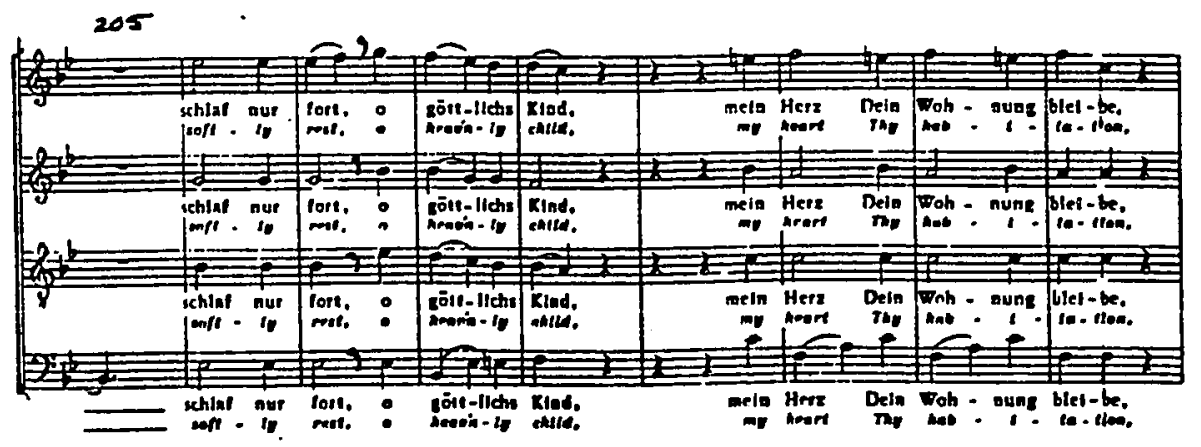

One approach to articulation is a light attack, then decay, followed by a slight separation without interrupting the line. This device is particularly effective on the ends of phrases and complements the 
rocking motion established in the string parts in measures $250 f$.

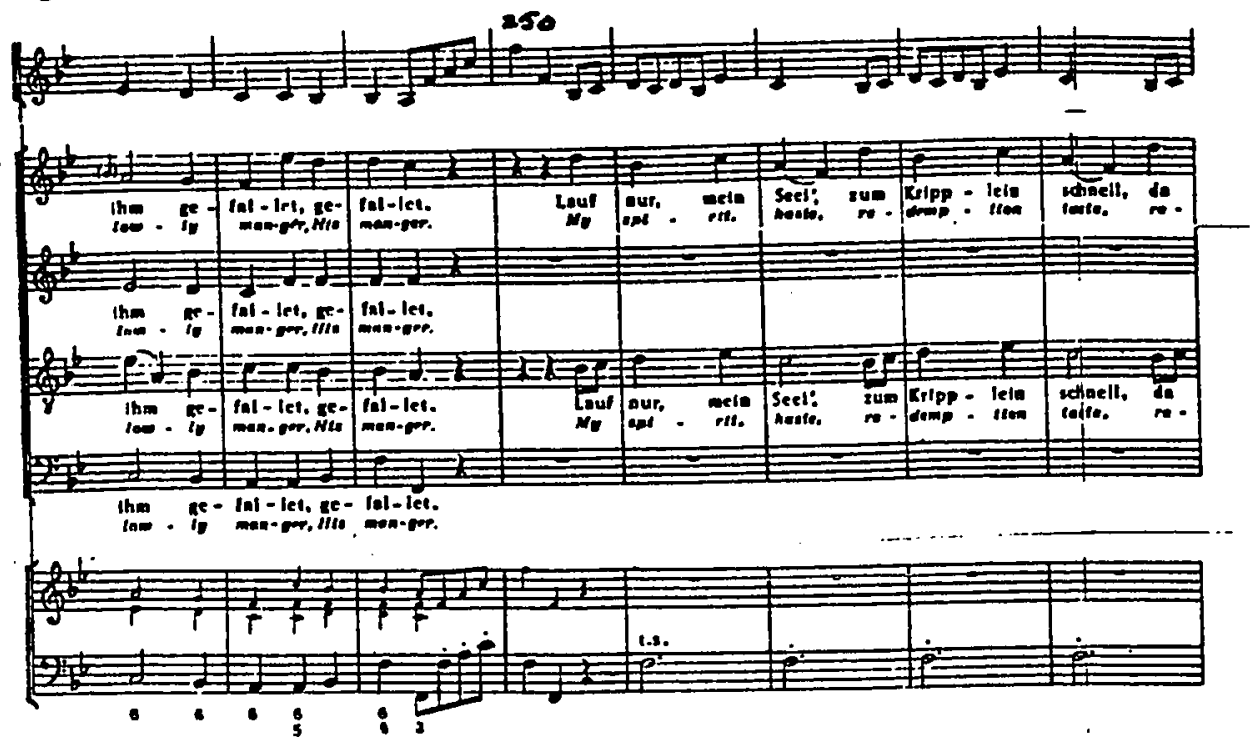

Through the text and music of this cantata, Haydn has fashioned a charming tableau of the Christmas story. Crucial in creating and naintaining the drama and vitality of this and comparative works, is the use of vocal articulation, patterned after the instrumental articulation practiced during the seventeenth, eighteenth and early nineteenth centuries in sacred music. Clear articulatory silences, non-legato singing, vivid slurs, motivic groupings by articulation, word stress, agogic accents (based on duration), and sharp metric accents provide the music with energy and verve. Without such axticulation and nuance, a performance is dull and lifeless.

\section{Ornamentation}

The attitude of the classical musician toward ornamentation was

42 Don Moses and Robert Denarec, "Articulation in Late Baroque Choral Music." The Choral Journal. XXXXVII (1987), p. 23. 
somewhat different than that of his baroque predecessor. No longer was the addition of ornamental devices freely shared between composer and performer as it had been in the arias or slow movements of the earlier period. In the Classical Period, composers wrote out most of the ornamentation either in notes or by using the conventional signs, however, certain occasions exist when improvising or adding ornaments is acceptable. Repeated sections of solo sonatas provide opportunities for dynamic changes, rhythmic variations and melodic alteration. As a rule, performers should avoid random use of ornamentation and improvisation wich would distort rather than enhance the stylistic character of the piece.

Ornamentation in the Classic Period, therefore, is generally thought of in respect to realizing the given ornamental figures and improvising cadenzas. Realization of ornamental figures is at times a difficult issue. - For example, there are conflicting views on the correct way to play a trill. C. P. E. Bach, Leopold Mozart, and J. J. Quantz, early classicists instructed players to begin a trill on the note above the main note. Composers such as Johann Hummel (1778-1837), Ludwig Spohr (1784-1859) and Carl Czerny (1791-1857) whose treatises appeared after the death of Beethoven, suggest beginning a trill on the main note. It is generally assumed "that the bulk of historical evidence seems to favor applying the ornamentation rules of the late Baroque period for most of the music of the classical period." "This

Ray Robinson and Allen Winold. The Choral Experience. (New York: Harper \& Row, Publishers, 1976), pp. 429, 439. 
is undoubtedly. true of Haydn's sacred music, since it is often more traditional than that of his contemporaries.

In Run, Ye Shepherds to the Light, the musical fabric in the beginning and ending movements is quite simple and free of superfluous decoration; however, Haydn has written in a few cadential trills in both the vocal and instrumental parts. Traditionally, cadential trills have had a harmonic function

which they fulfil by behaving like appoggiaturas, accented from the upper (i.e. the auxiliary) note, on the beat, so that the hamony is heard from that upper note, to which the main note then serves like a resolution. 44

Usually when cadential trills are written into a vocal part, they appear in conjunction with a trill in an accompanimental line as well. However, the trill in the soprano line at measure 24 of the first movement is not reinforced by the strings as the moving eighth-note figures in the violins would be interrupted by even a short trill. For instrumental complement of the vocal trill, the keyboardist should insert a trill, making it correspond in length with the vocal trill. Though not included in the score, a similar trill could be added to the final cadence of the soprano line in measure 53 of the same movement. (See illustrations on page 35.)

\footnotetext{
44

Donington, Baroque Music., p. 125. 45

Frederick Neumann. - Ornamentation and Improvisation in Mozart. (Princeton, NJ: Princeton University Press, 1986), p. 16.
} 

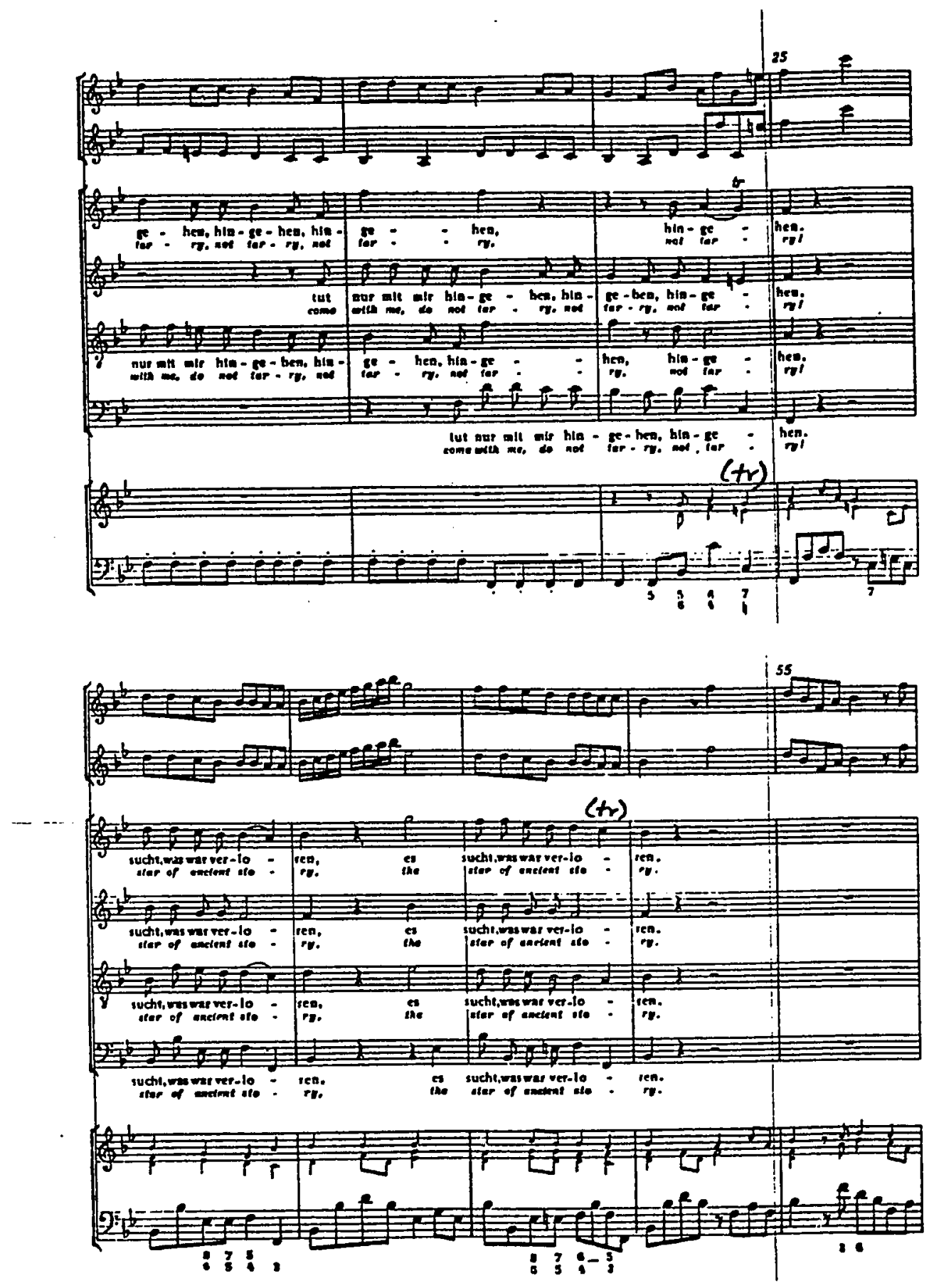

In the third movement, Haydn has written in a trill in the soprano part at the cadence in measure 221. Again, nothing is written out for the strings, but since the first violin doubles the soprano line, a trill should be played. For clarity and practicality, the trill should 
be short, perhaps two repetitions of the auxiliary and main note.

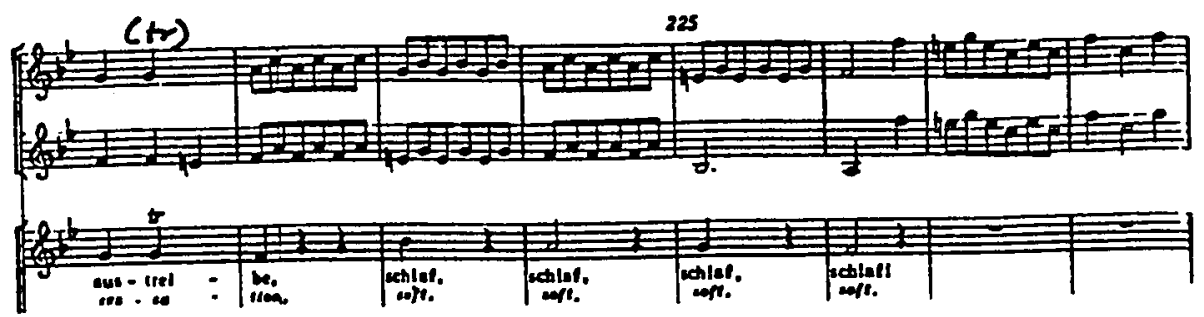

Trills appear in the second movement aria with greater frequency both serving a harmonic function as well as a decorative one. In measures 64,73 and 77 of the introduction (See Appendix A), the trills in the first violin part provide harmonic enphasis. Melismatic trills in the soprano voice add brilliance and decorative emphasis to the melodic line.

Another ornament used extensively in baroque and classical composition is the appoggiatura. The appoggiatura is "an auxiliary note, usually dissonant, always stressed, on the beat and slurred to its declining resolution on the main note." ${ }^{46}$ Appoggiaturas were used to enhance the harmonic progression and to aod expressiveness to the melodic line.

The question that arises when performing classical music, is how long does one hold the auxiliary note? Frederick Neumann, an authority on ornamentation in Mozart's music claims that

in slow or moderate tempos as well as in cantabile passages in a lively tempo, they will tend to be of the 'long' species, but will rarely exceed that of a quarter note. 47 
The second movement contains many appoggiaturas, both in the string parts and in the soprano solo line. In the first violin part, the appoggiaturas usually precede quarter-notes which when performed make both auxiliary and main note even eighth-notes.
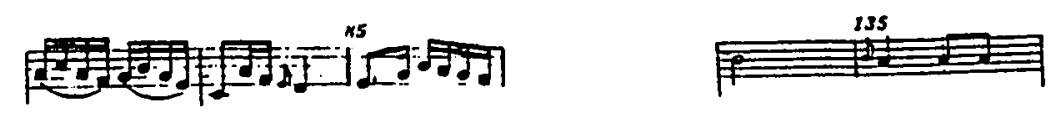

On one occasion, in measure 143, the appoggiatura precedes an eighthnote followed by a descending sixteenth-note run. In this case, the auxiliary and main notes would be performed as even sixteenth-notes.

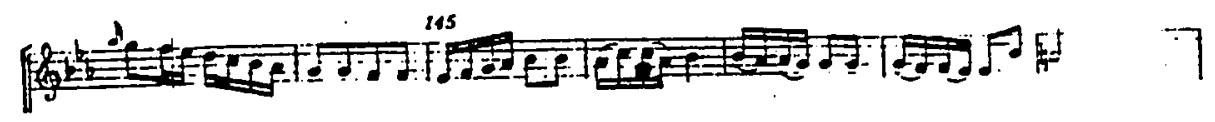

The soprano part corresponds in most cases with the violin line. There are a couple of instances when the text may cause some confusion in respect to the execution of the appoggiaturas. In measure 155, the main note would be treated as a dotted quarter-note since the word "a" is sung on the last eighth beat. This might suggest that the auxiliary note could be held longer, equal to one quarter-note. Neumann contencis, however, that "before dotted notes, the preceding note will rarely exceed one-third of the latter's value" ${ }^{48}$ which in this case would be the customary eighth-note.

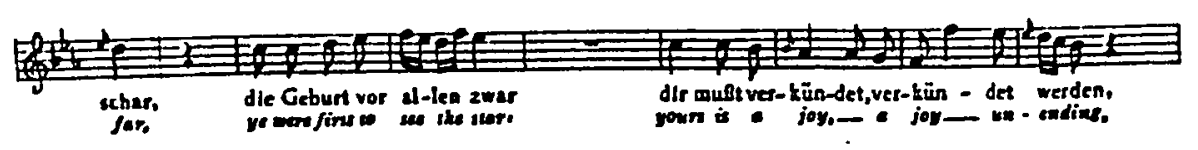

In some instances, Haydn has written out the apooggiaturas as in measure 209. Further emphasis and expressiveness can be added to this

48 Neumann, Ornamenting in Mozart., g. 30. 
key word by creating a slight silence before the appoggiatura, as indicated:

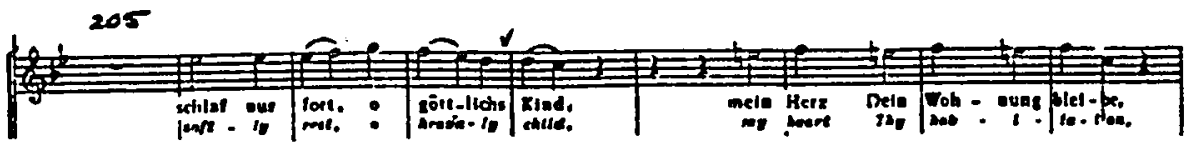

There is one instance of a grace note or accacciatura. An accacciatura occurs when the dissonant auxiliary note is struck with the main note on its beat then rapidly released. Appearing only once in the first violin part at measure 48 , this ornament would not be performed as an appoggiatura as that would create an unnatural dissonance in the ascending unison line of the voices.

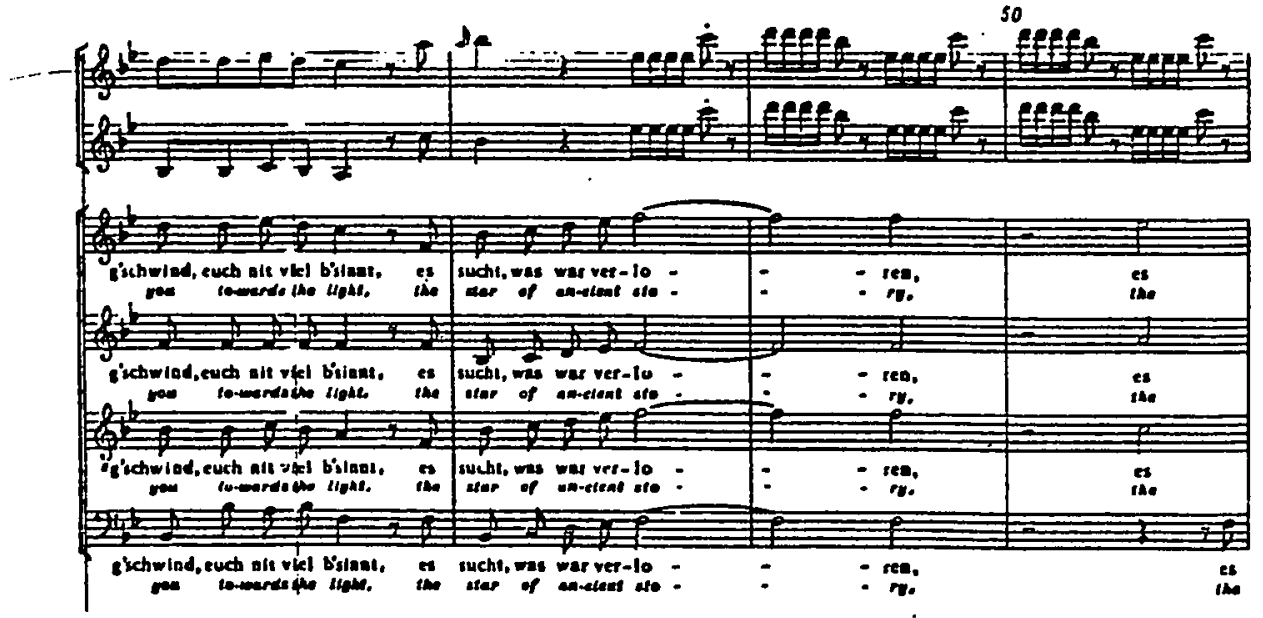

Ornaments are one of several devices used in the Classical period to add style, grace and elegance to the music. As Thurston Dart suggests:

Ornaments are delicate, instinctive things; if they are not ormamental they are worse than useless, and anxiety about the right way to play then must never be allowed to cloud a performer's 
sense of the underlying structure of the music they adorn.49

Dart, The Interpretation of Music., p. 102. 


\section{Chapter 5}

Summary and Conclusions

Historically, Johann Michael Haydn, has indeed been overshadowed by his brother Joseph, and by his friend and colleague, Wolfgang A. Mozart. Both prolific composers, Joseph Haydn and Mozart produced music that was often innovative, occasionally daring and at times not totally understood. Michael Haydn, also quite prolific yet perhaps more circumspect, produced rnusic that was dignified, expressive and artfully crafted. Joseph Haydn and Mozart, for the most part, wrote their most menorable works for the opera stage and concert hall. In contrast, Michael Haydn composed his best works for the church. It was never Haydn's aim to charm the musical world with his novelty and daring, but instead he sought to compose music that was sensitive and sublime. iJnfortunately, Michael lived during a time when music for the church was on the decline.

Much is to be learned about Michael Haydn. As Elwyn wienandt states in his book, Choral Music of the Church, Haydn

may represent the end of a long line of composers
who dedicated themselves to the Catholic church
and who produced liberally and with excellent
quality. The names that live are those of
composers who made their reputations in the world
of the opera house and the concert salon. 50

Michael Haydn, whether voluntarily or involuntarily, chose to write his best works for the church, and seemingly as a result, nearly slipped fron the pages of musical history. Yet he is one composer who should 
not be forgotten. In his masses, his many graduals and motets, and his cantatas, Haydn demonstrated a keen awareness of musical and textual affinity and also of religious propriety. To the knowing musician, Michael Haydn's music is as worthy of performance now, as it was 2 , years ago.

50

Wienandt, Choral Music of the Church., pp. 216, 217. 


\section{BIBLIOGRAPHY}

Badura-Skoda, Eva and Paul. Interpreting Mozart on the Keyboard. (London: Barrie and Rockliff, 1962).

Baker's Biographical Dictionary of Musicians. Nicolas Slonimsky, editor. Sixth Edition. (New York: Schirmer Books, 1978).

Dart, Thurston. The Interpretation of Music. (New York: Harper and Row, Publishers, 1963).

Donington, Robert. Baroque Music: Style and Performance. (New York: W. W. Norton \& Company, 1982).

Dorian, Frederick. The History of Musical Performance. (New York: $W$. w. Norton \& Company, 1942).

Fiske, Roger, "The Viennese Classic Period." Choral Muslc: A Symposium. Arthur Jacobs, editor. (Middlesex, England: Penguin Books, Ltd., 1963).

Greene, David Mason. Greene's Biographical Encyclopedia of Composers. (Garden City, NY: Doubleday \& Company, Inc., 1985).

Grout, Donald J. A History of Western Music. Third Edition. (New York: W. W. Norton \& Company, 1980).

Harvard Concise Dictionary of Music. Don Michael Randel, editor. (Cambridge, MA: The Belknap Press, 1978).

"Haydn, (Johann) Michael," in The New Groves Dictionary of Music and Musicians. Stanley Sadie, editor. (London: Macmillan Publishers, Ltd., 1980).

Haydn, Johann Michael. Missa Hispanica. Charles H. Sherman, editor. (Salzburg: Haydn-Mozart Press, 1966).

Haydn, Johann Michael. Missa Pro Defunctis. Charles H. Sherman, editor. (Columbia, MO: University of Missouri Press, 1969).

Hayan, Johann Michael. Missa Sancti Hieronymi. Charles H. Sherman, editor. (Columbia, MO: University of Missouri Press, 1976).

Hayån, Johann Michael. "Prope Est Dominus," Percy M. Young, editor. (New York: Broude Brothers, Ltd., 1976).

Haydn, Johann Michael. Run, Ye Shepherds to the Light (Lauft, Ihr Hirten Allzugleich). Elwood Jay Johnson, editor. (Bryn Mawr, PA: Theodore Presser Company for Coronet Press, 1982). 
Keller, Hermann. Phrasing and Articulation. (New York: W. W. Norton and Company, Inc., 1965).

Key Words in Church Music. Carl Schalk, editor. (st. Louis: Concordia Publishng House, 1978).

"Lauft, ihr Hirten allzugleigh," Polyphonia Sacra. Rudolf Ewerhart, editor. (Laaber, Germany: Laaber-Verl $\overline{a g, ~ 1985) . ~}$

Mac Intyre, Bruce C. The Viennese Concerted Mass of the Early Classic Period. (Ann Arbor, MI: UMI Research Press, 1986).

Moses, Don and Robert Demarec, "Articulation in Late Baroque Choral Music." The Choral Journal. XXXXXVII (1987).

Moses, Don V., Robert W. Demarec and Allen F. Ohmes. Face to Face With an Orchestra. (Princeton, New Jersey: Prestige Publications, Inc., 1987).

"Motets of Michael Haydn and Mozart, The," Journal of the American Musicological Society. IX (1956).

Neumann, Fredrick. Ornamentation and Improvisation in Mozart. (Princeton, New Jersey: Frinceton University Press, 1986).

Pauly, Reinhard. Music in the Classic Period. Second Edition. (Englewood Cliffs, NJ: Prentice-Hall, Inc., 1973).

Robertson, Alec. Requiem: Music of Mourning and Consolation. (London: Cassell \& Company, Ltd., 1967).

Robinson, Ray and Allen Winold. The Choral Experience. (New York: Harper \& Row, Publishers, 1976).

Rosen, Charles. The Classical Style. (New York: W. W. Norton and Company, Inc., 1972).

Ulrich, Homer. A Survey of Choral Music. (San Diego: Harcourt Brace Jovanovich, Publishers, 1973).

Wienandt, Elwyn A. Choral Music of the Church. (New York: The Free Press, 1965).

Young, Percy M. The Choral Tradition. (New York: W. W. Norton and Company, Inc., 1962). 


\author{
APPENDIX A \\ Lauft, ihr Hirten, allzugleich \\ (Run, Ye Shepherds to the Light) \\ by \\ Johann Michael Haydn
}

Note: This transcription contains a few editorial suggestions. Included are:
a) an English translation,
b) a realization of the figured bass,
c) footnotes regarding the realization of ornaments,
d) metronome markings, and
e) dynamic markings (in parentheses).

These markings are intended to provide the conducter/performer with ideas for a more authentic and stylistically correct interpretation.

Please see page 17 for further information. 

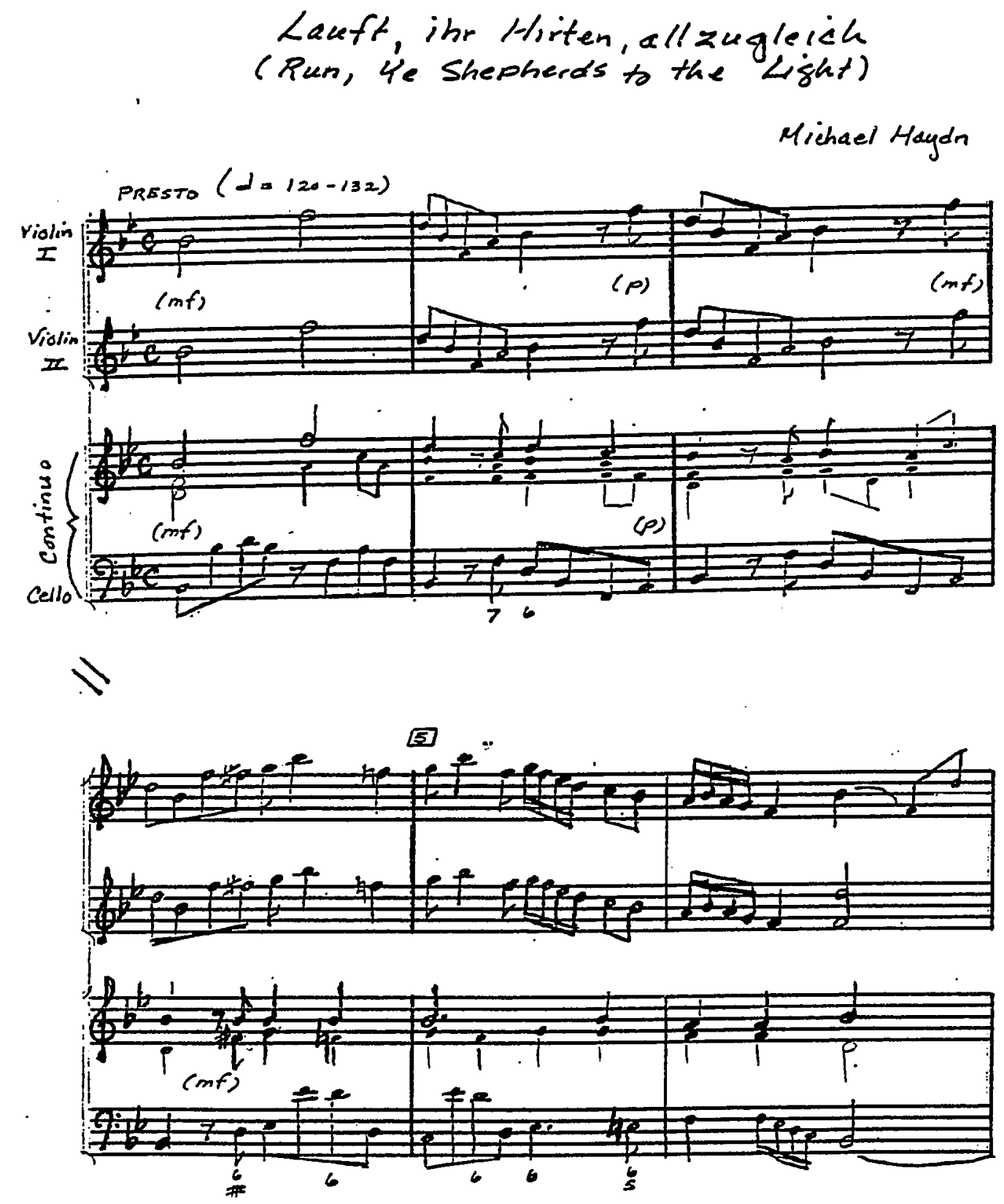

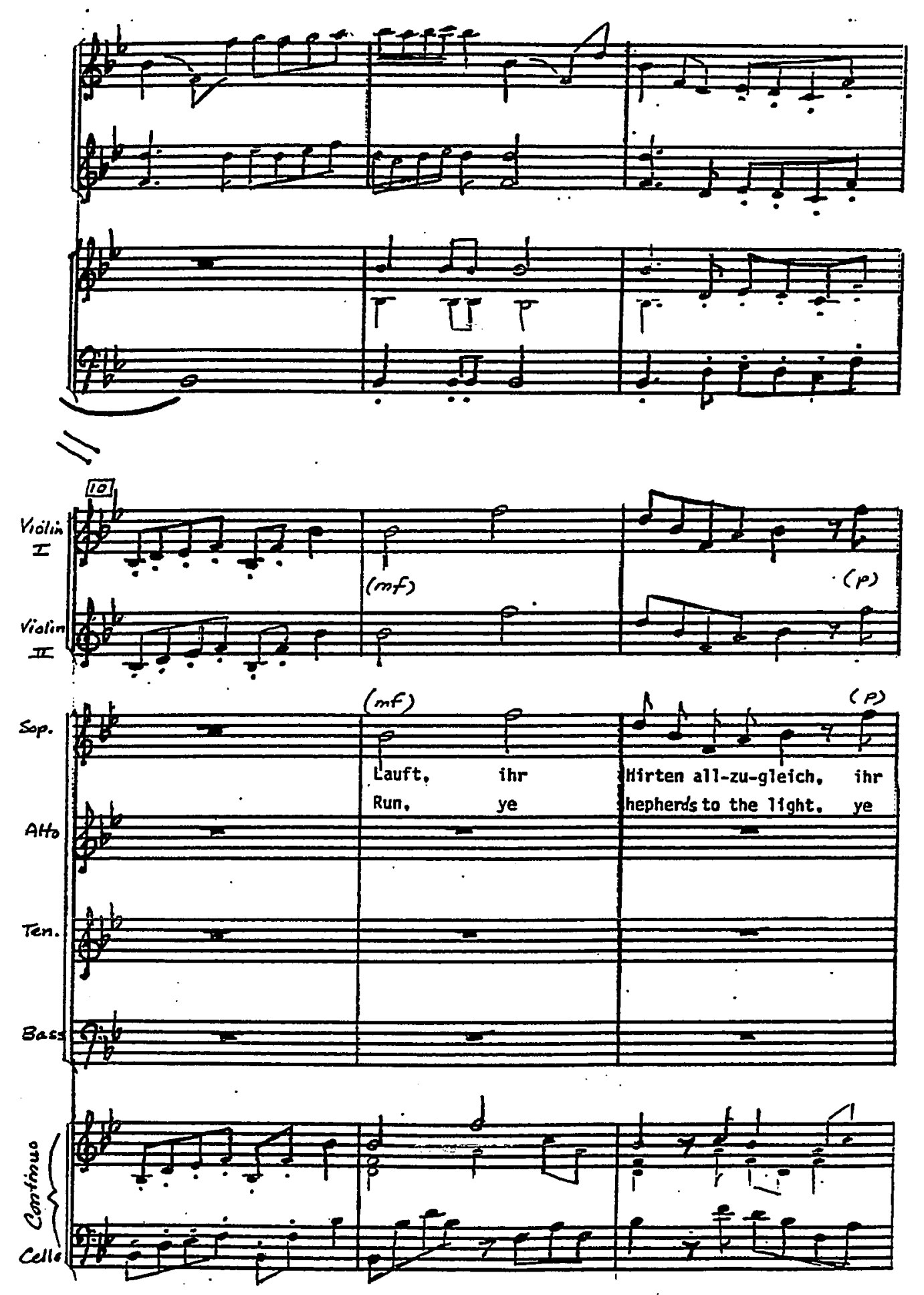


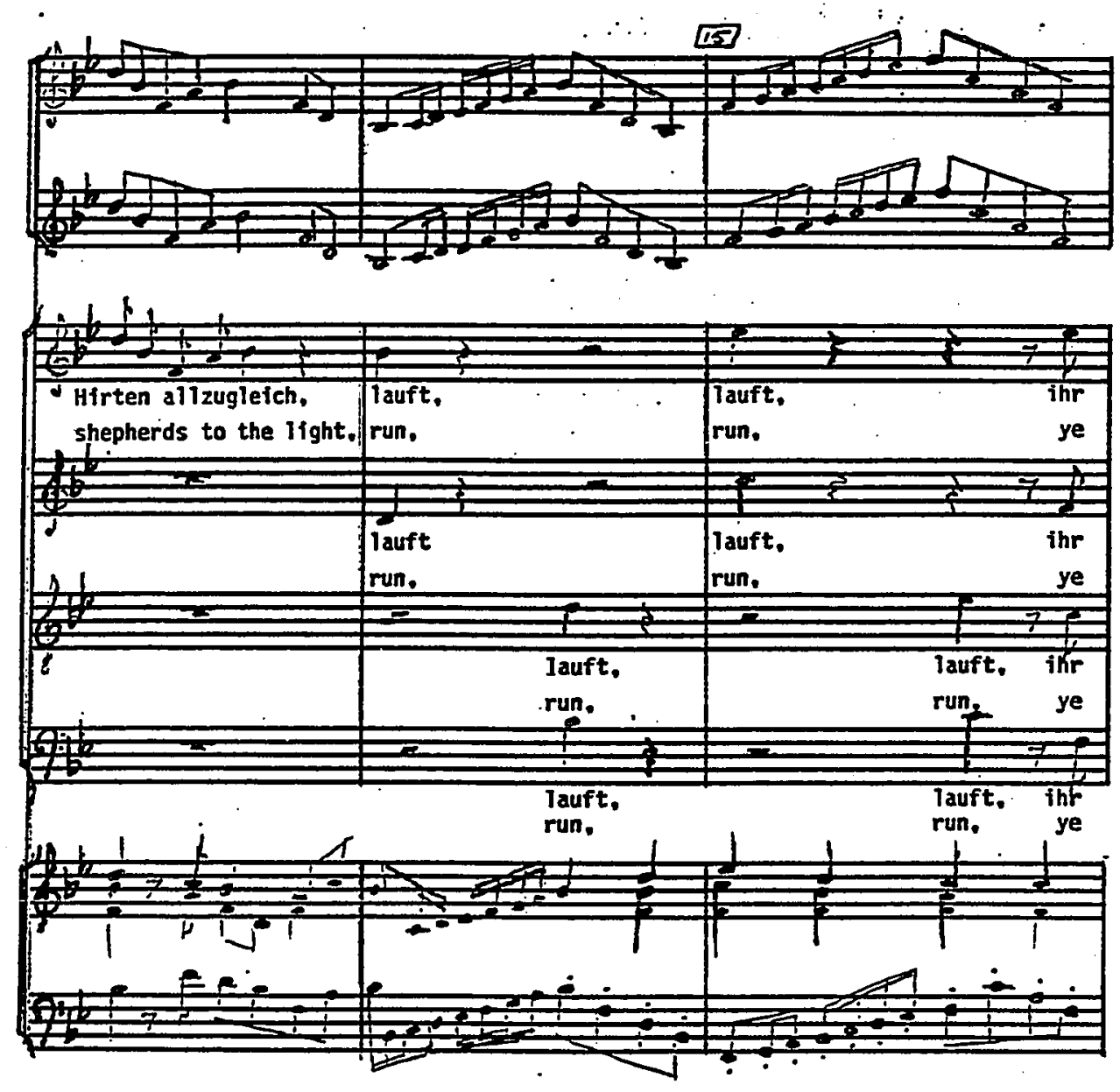




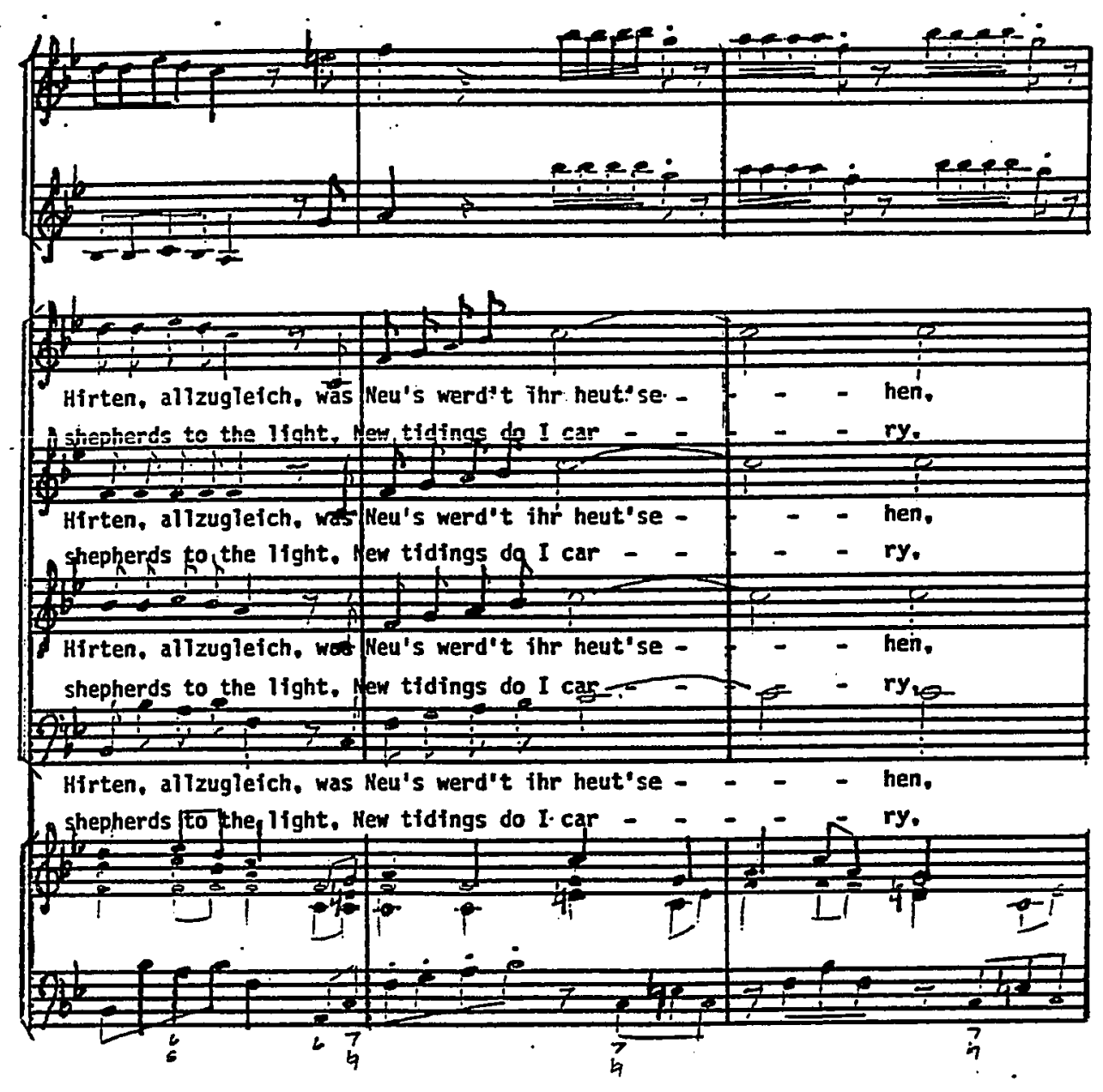




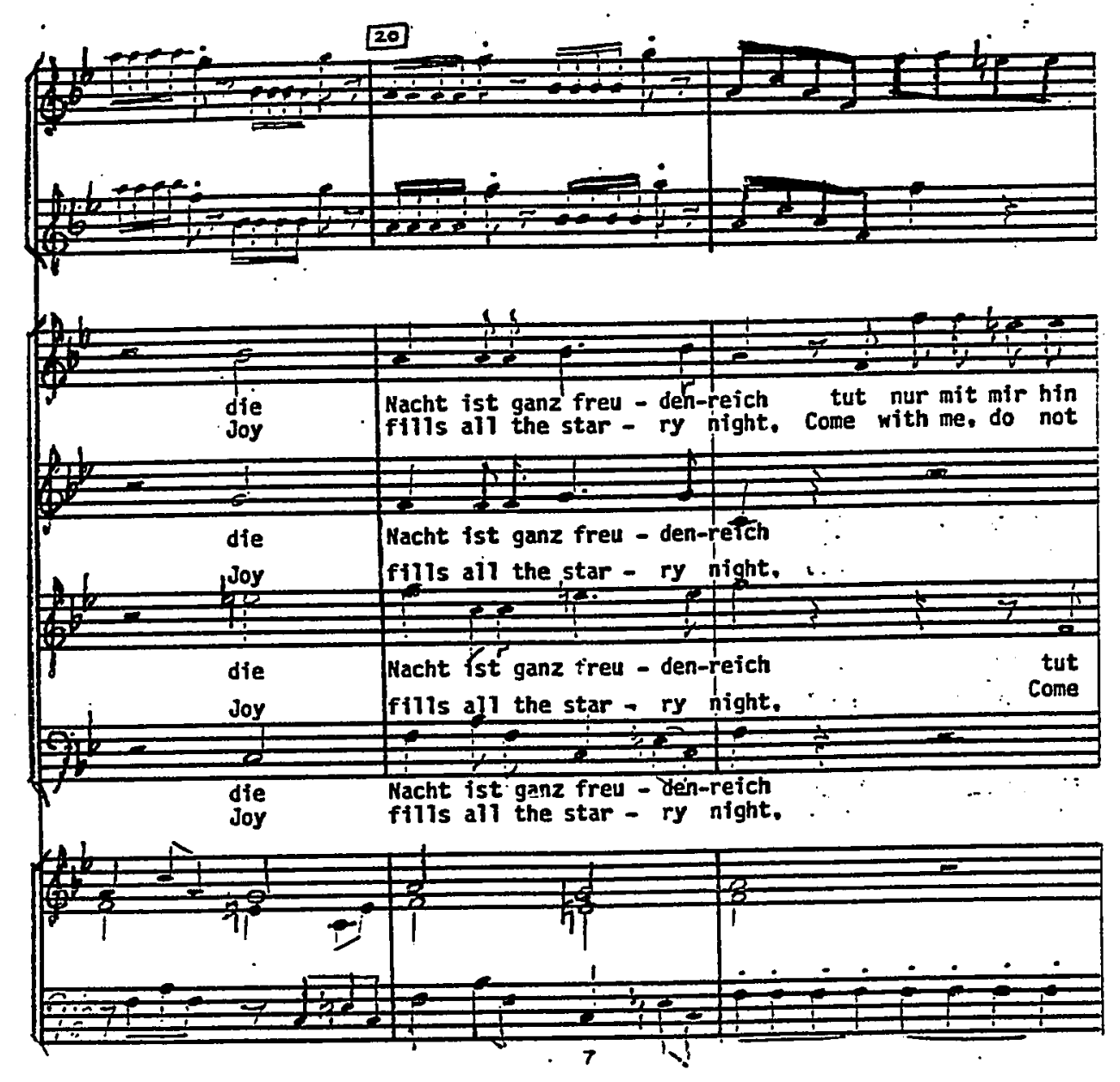




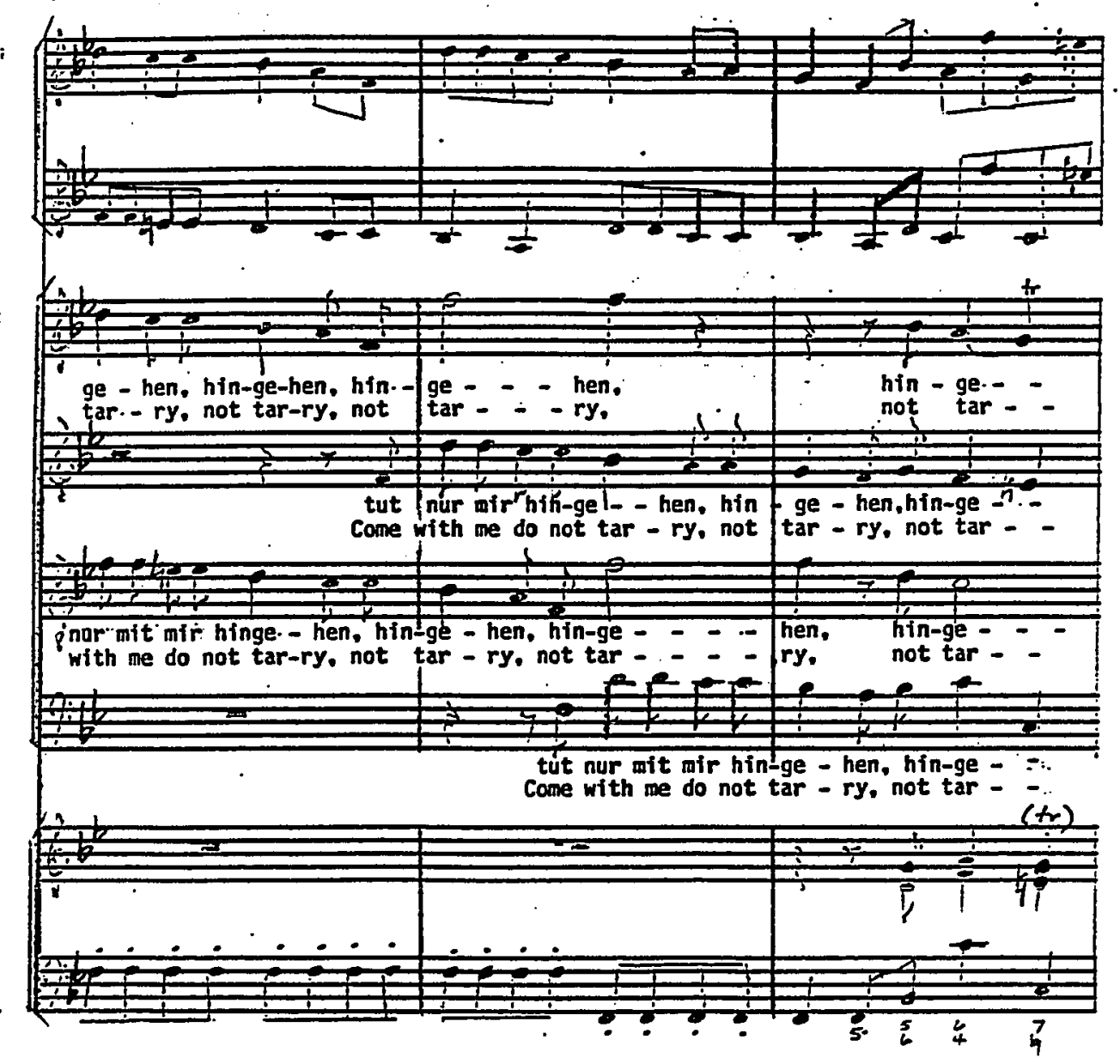




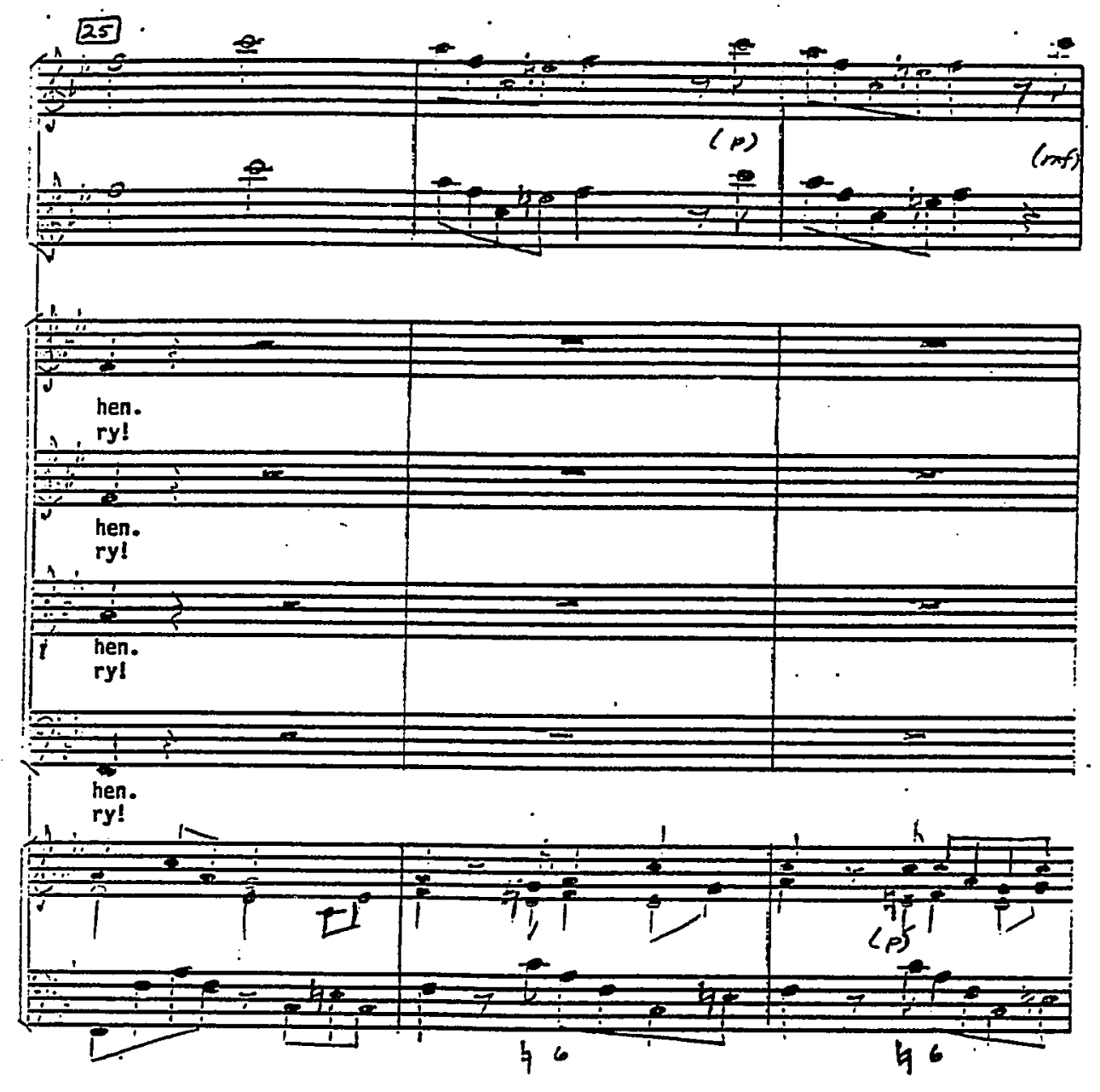



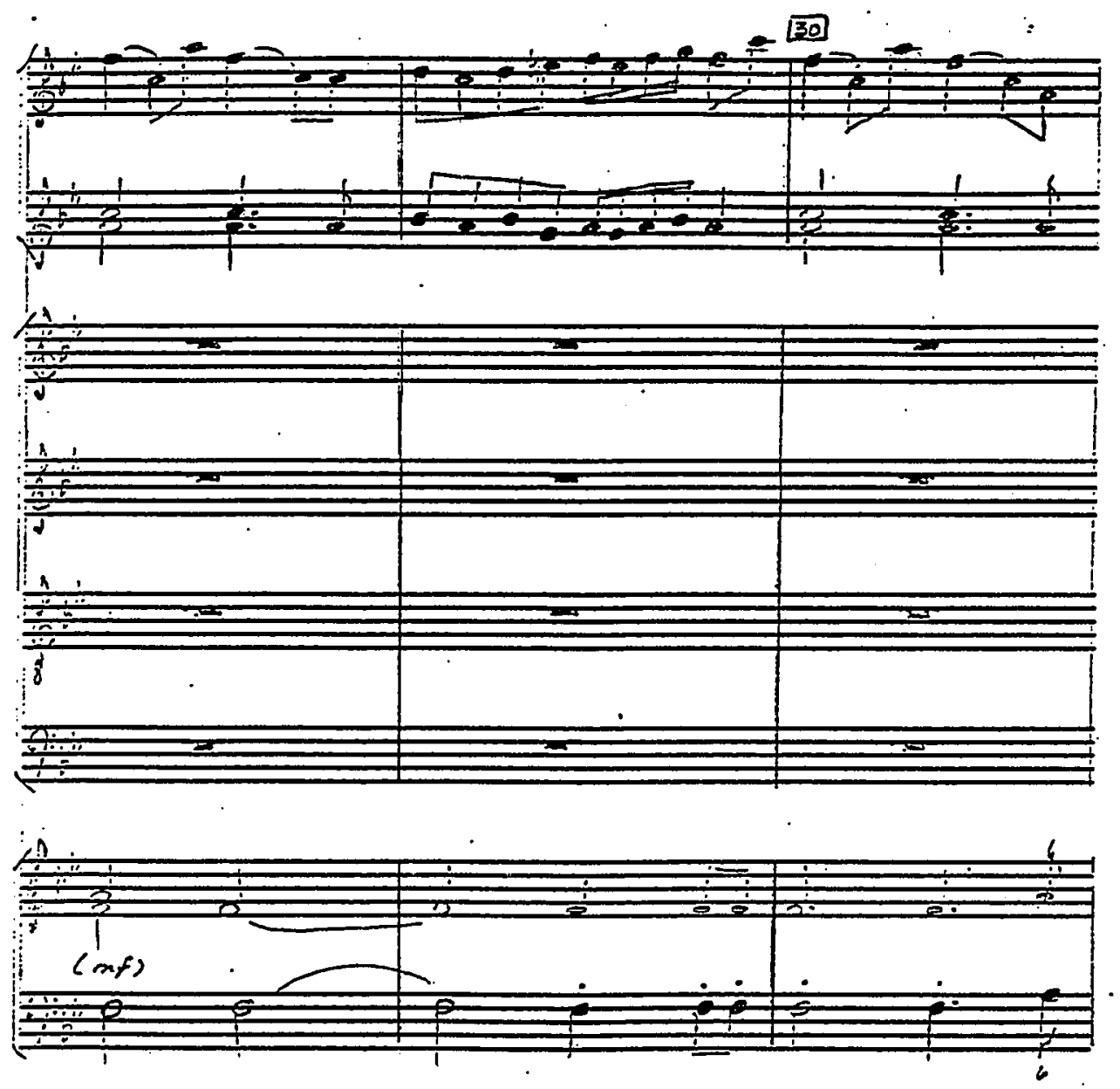


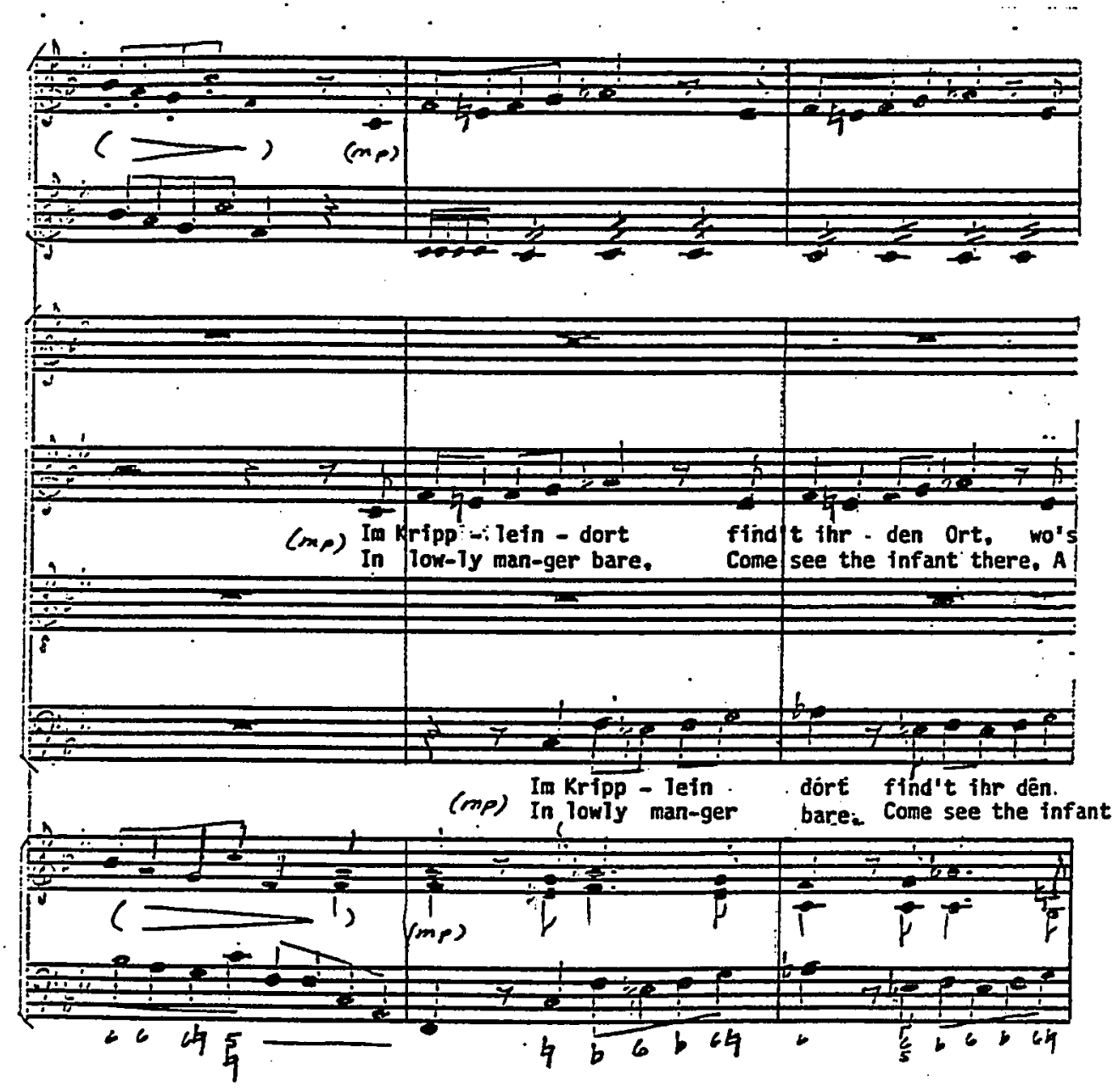




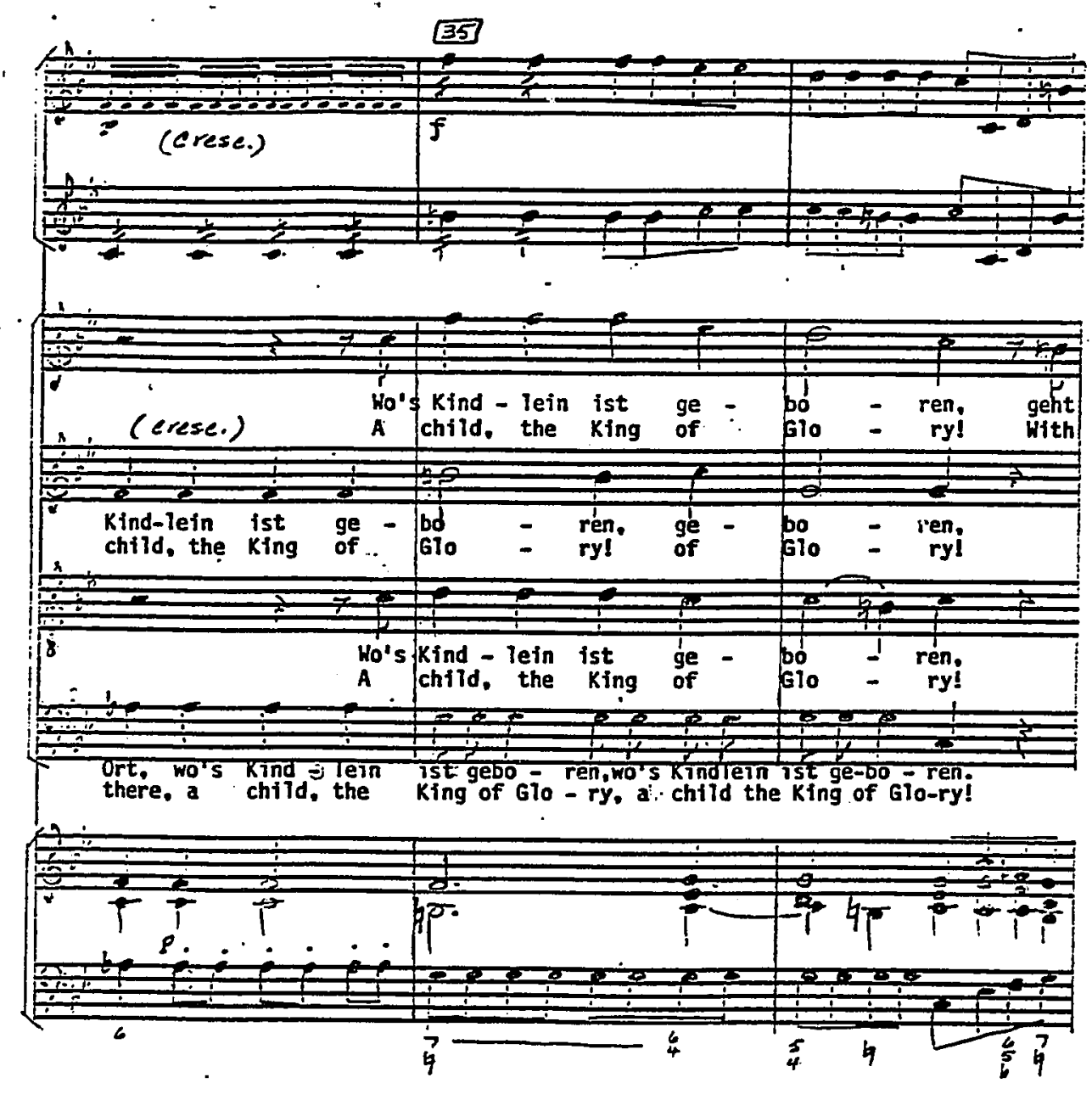




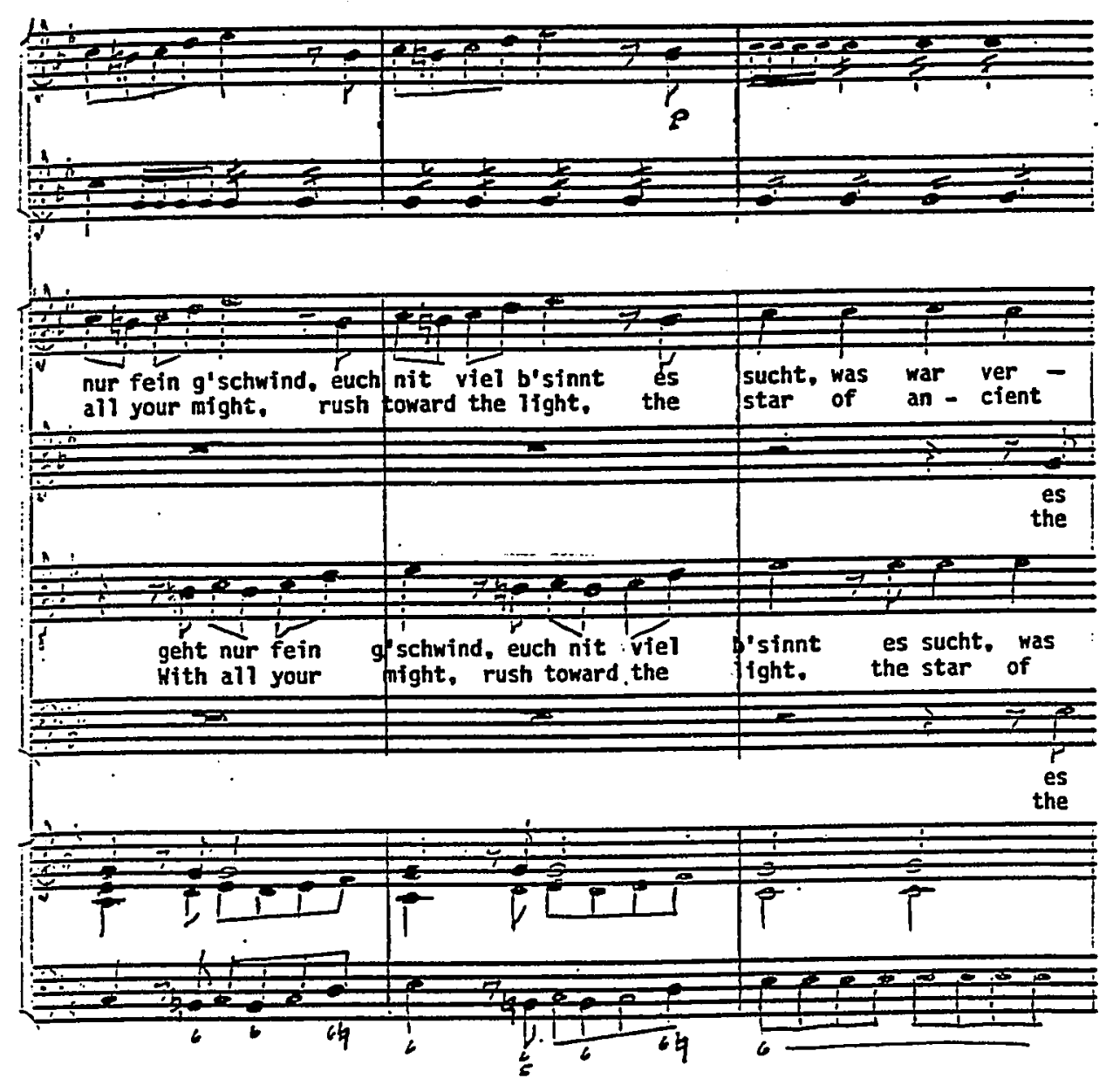




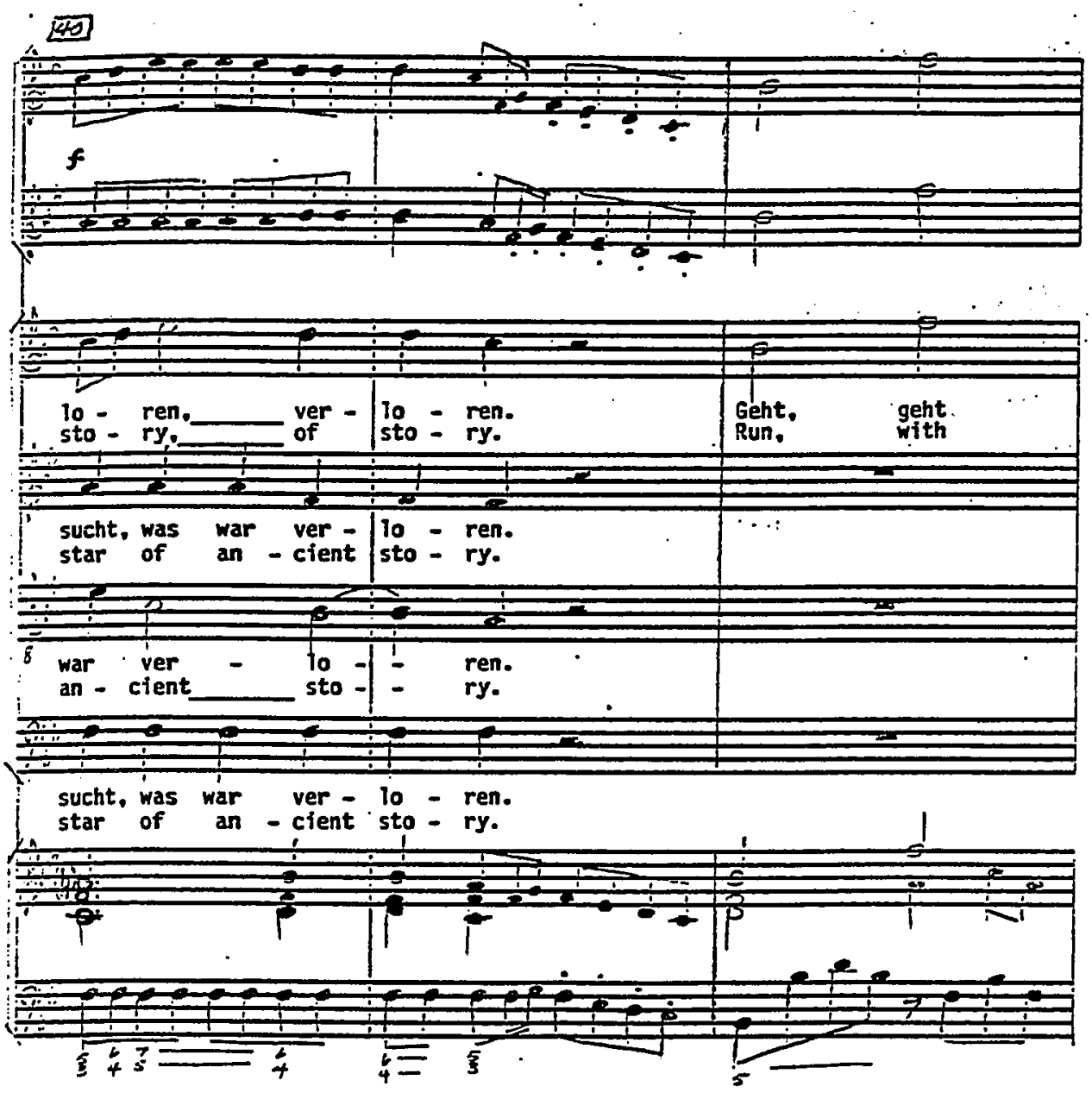




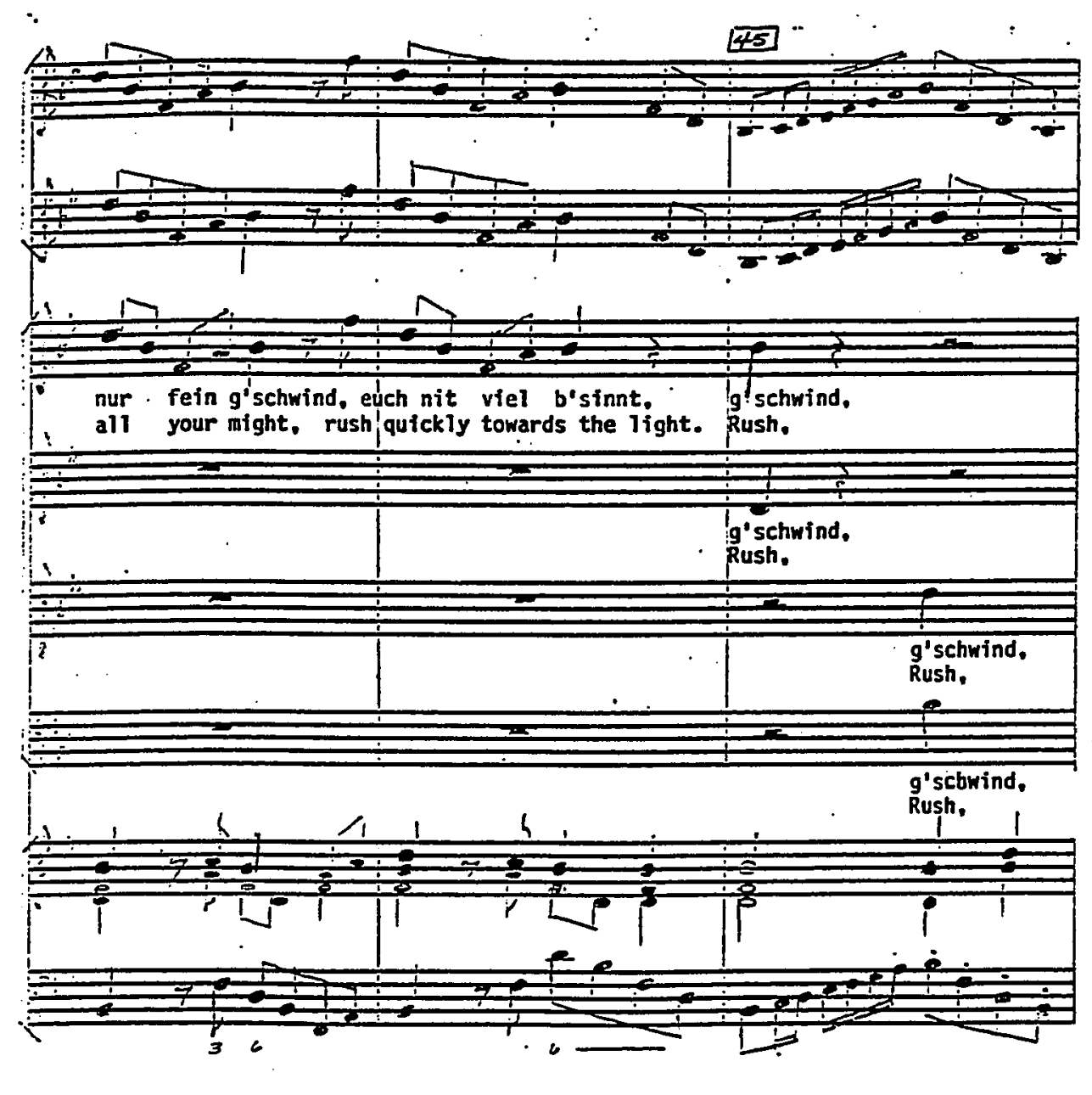




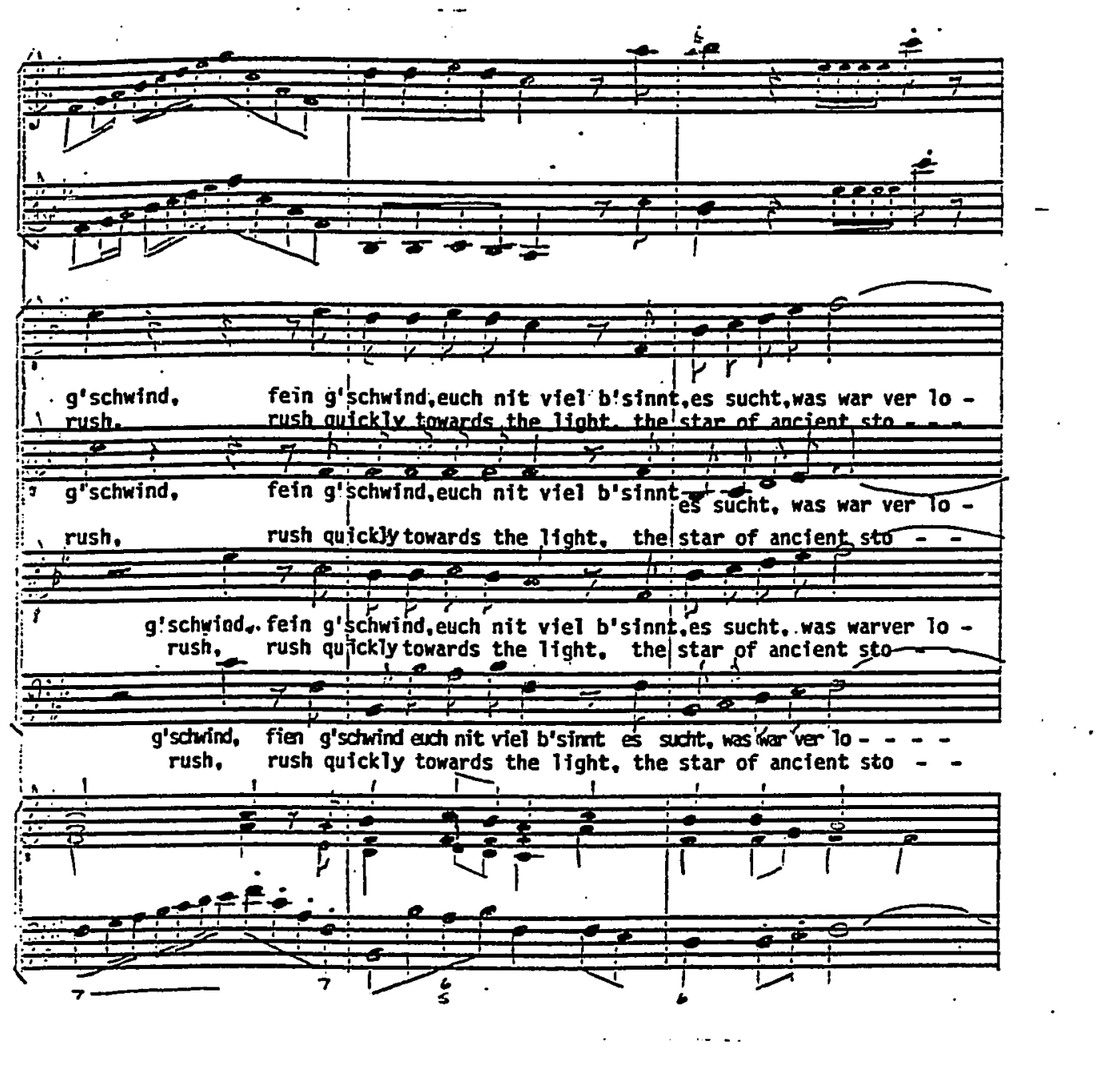




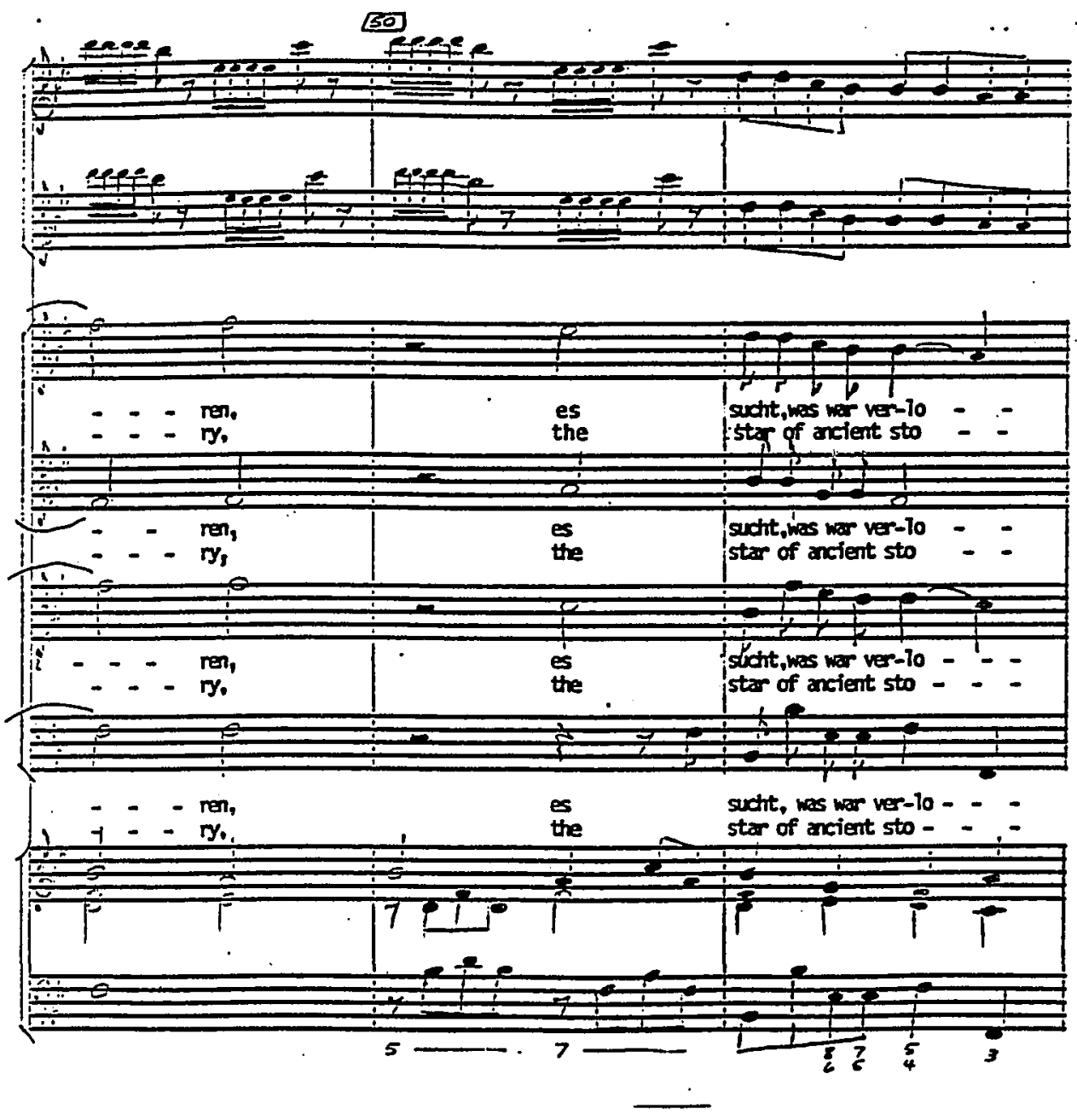




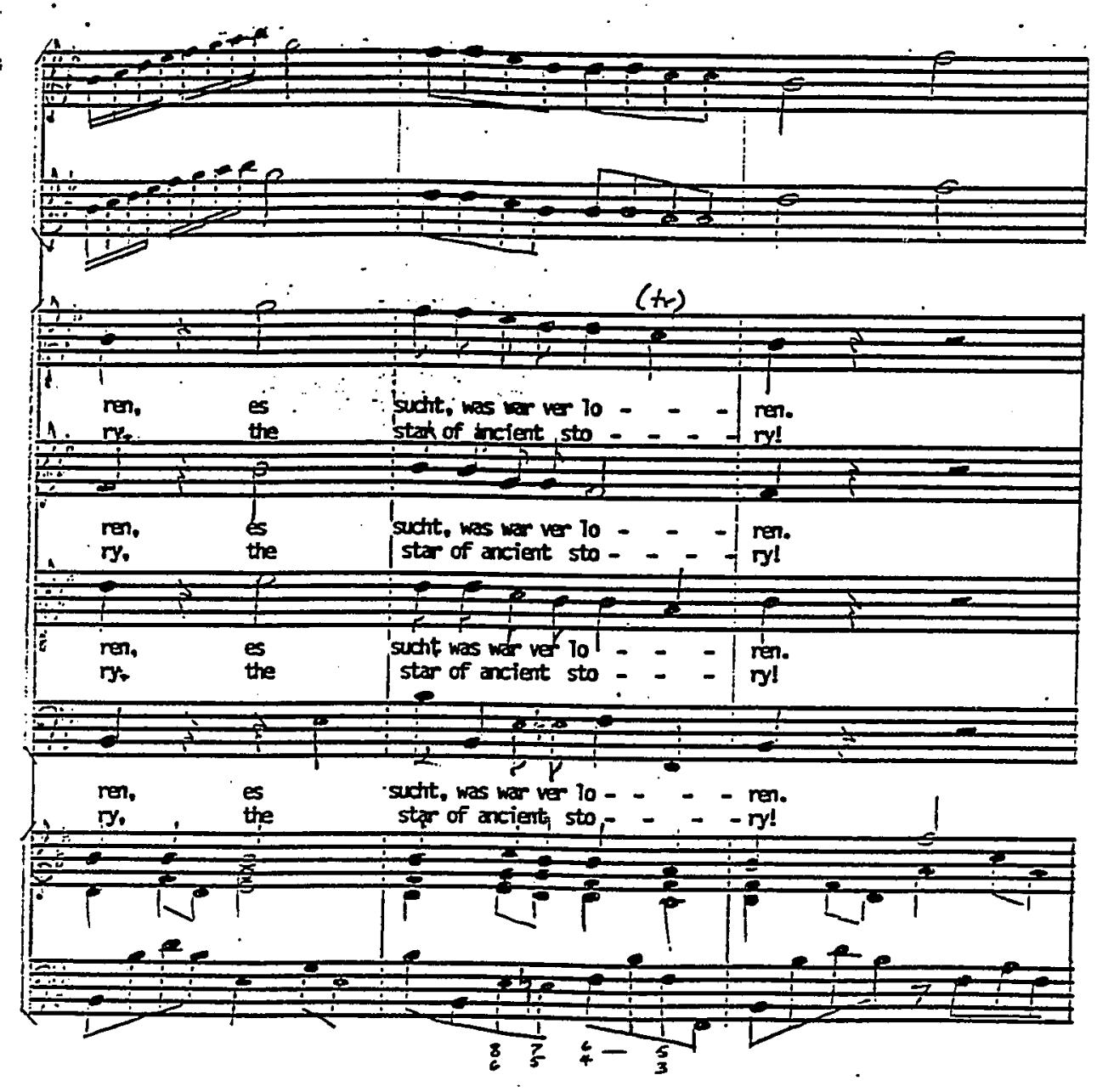




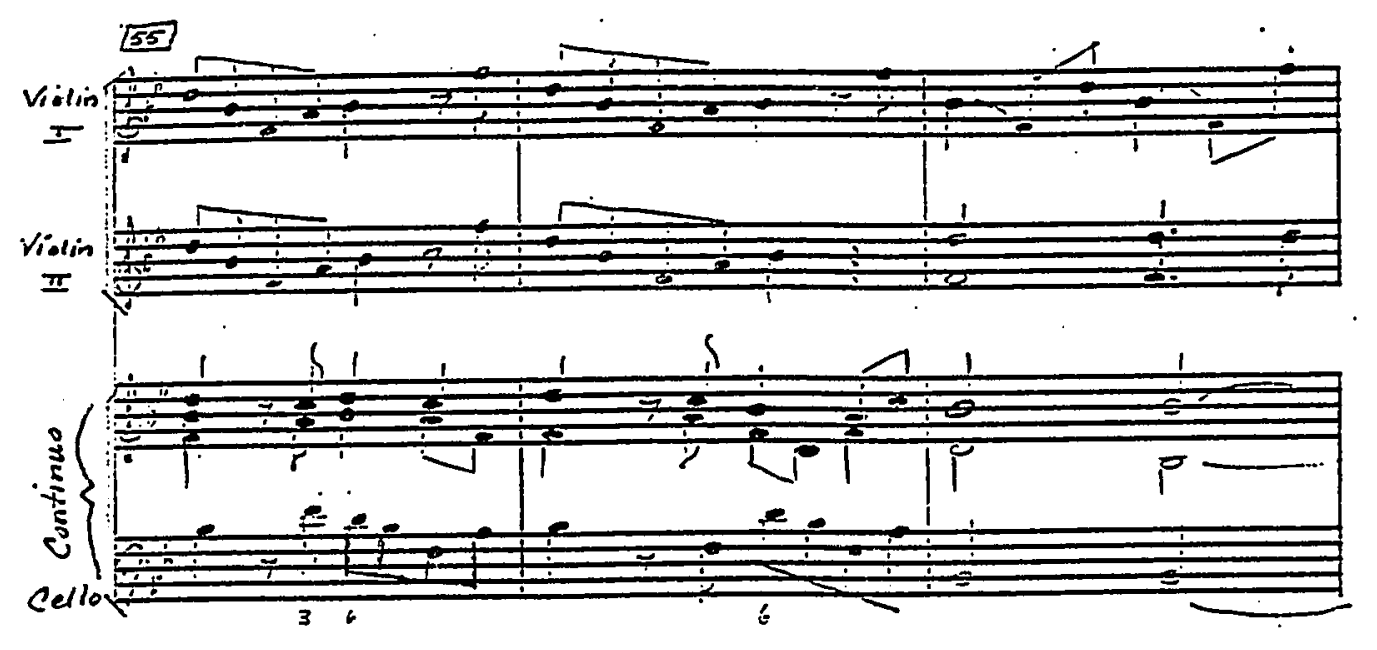

$\$$

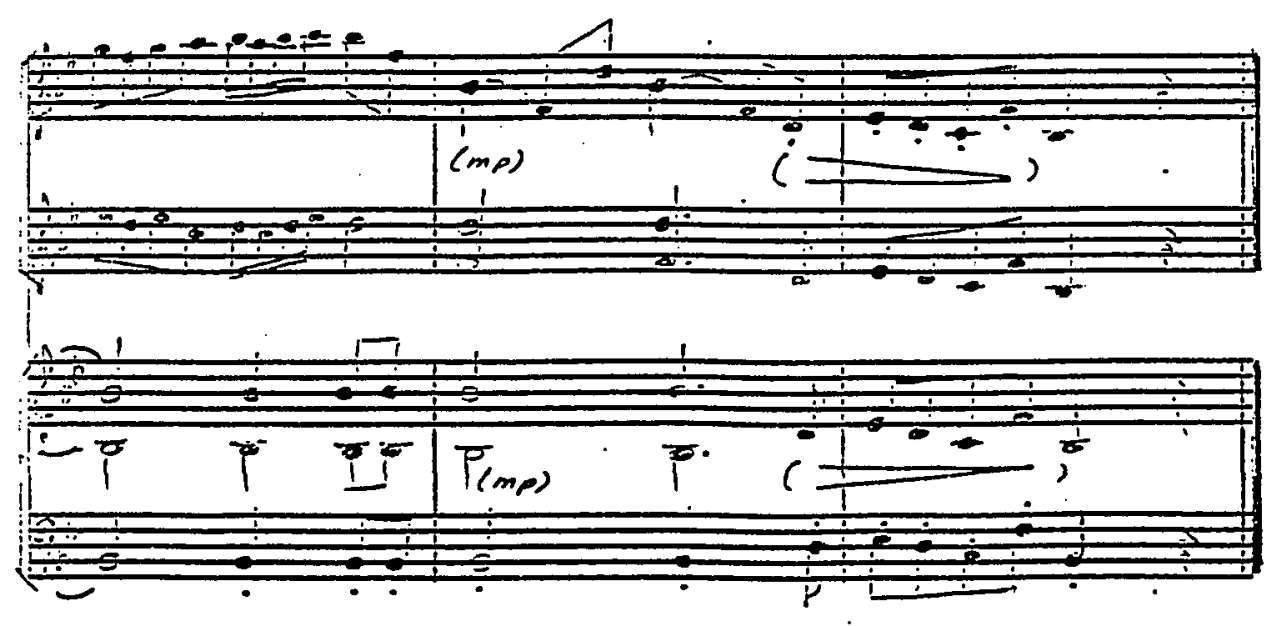




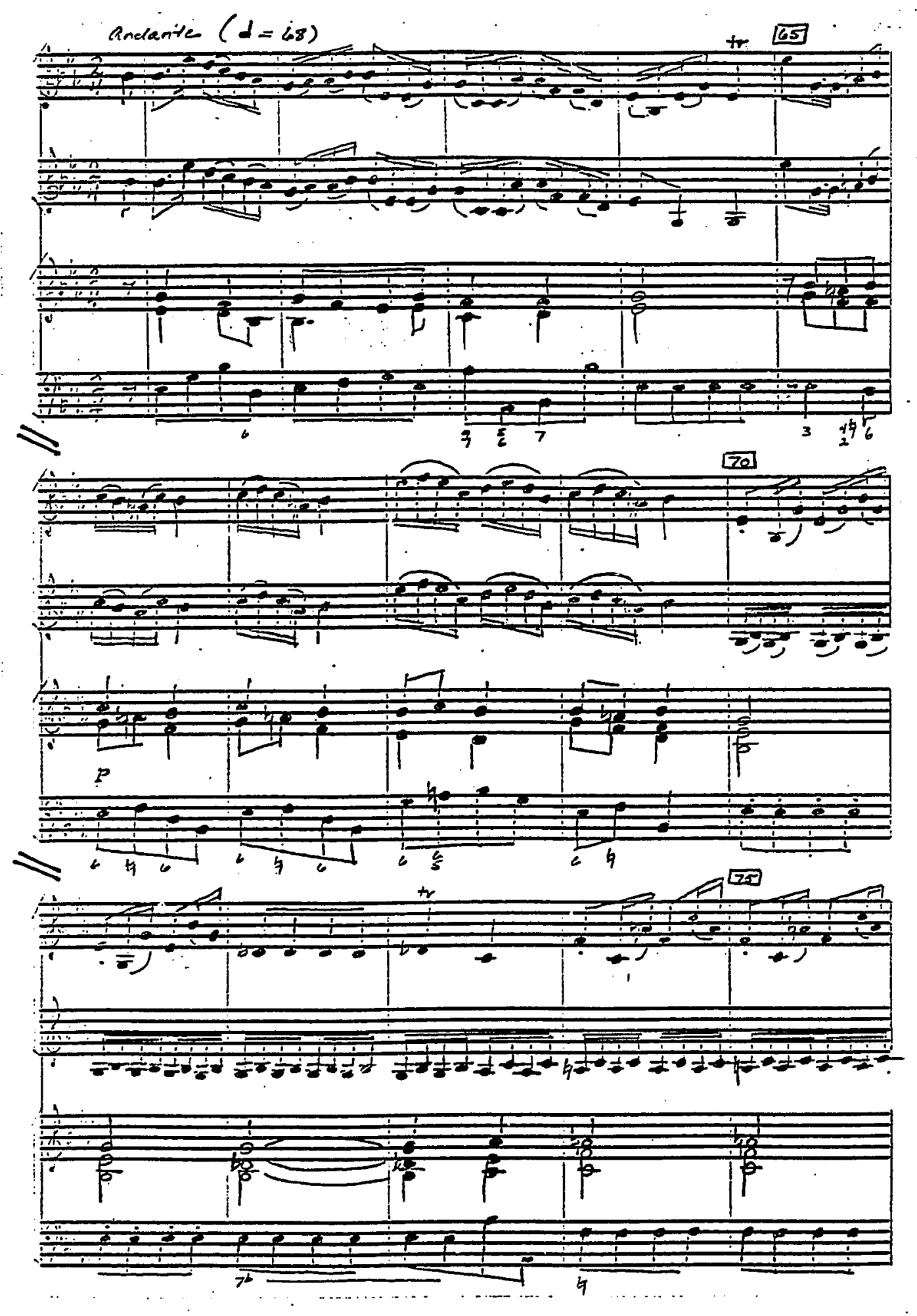




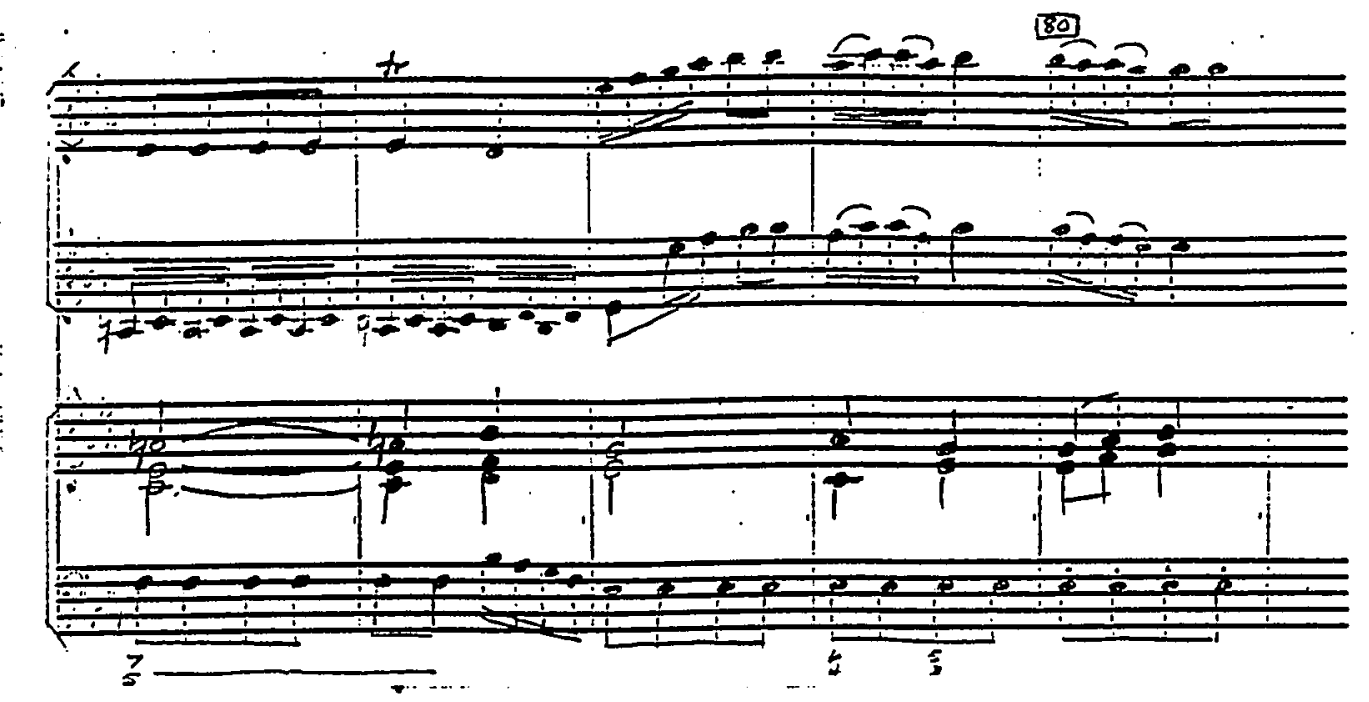

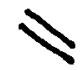
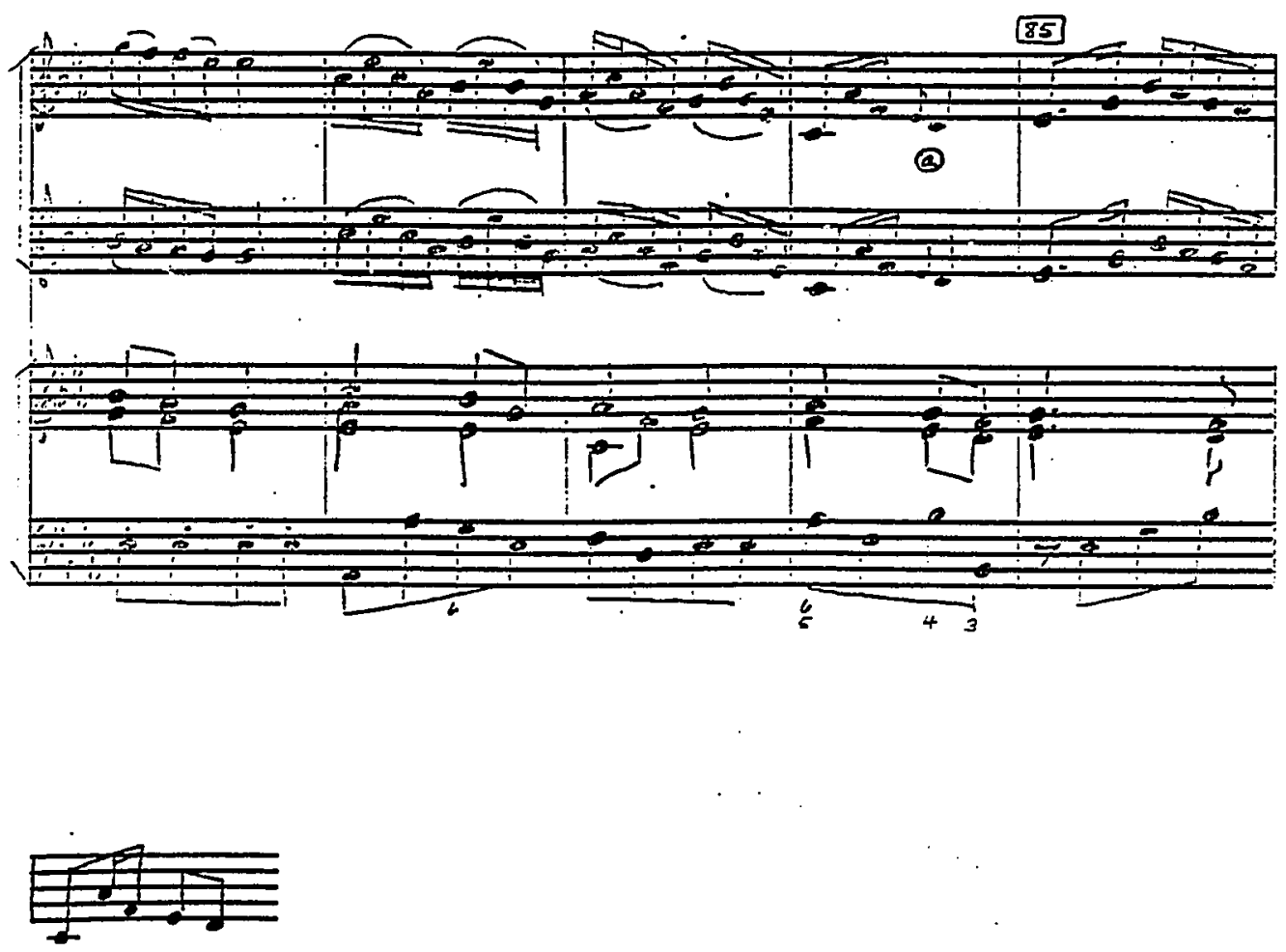

(2) 


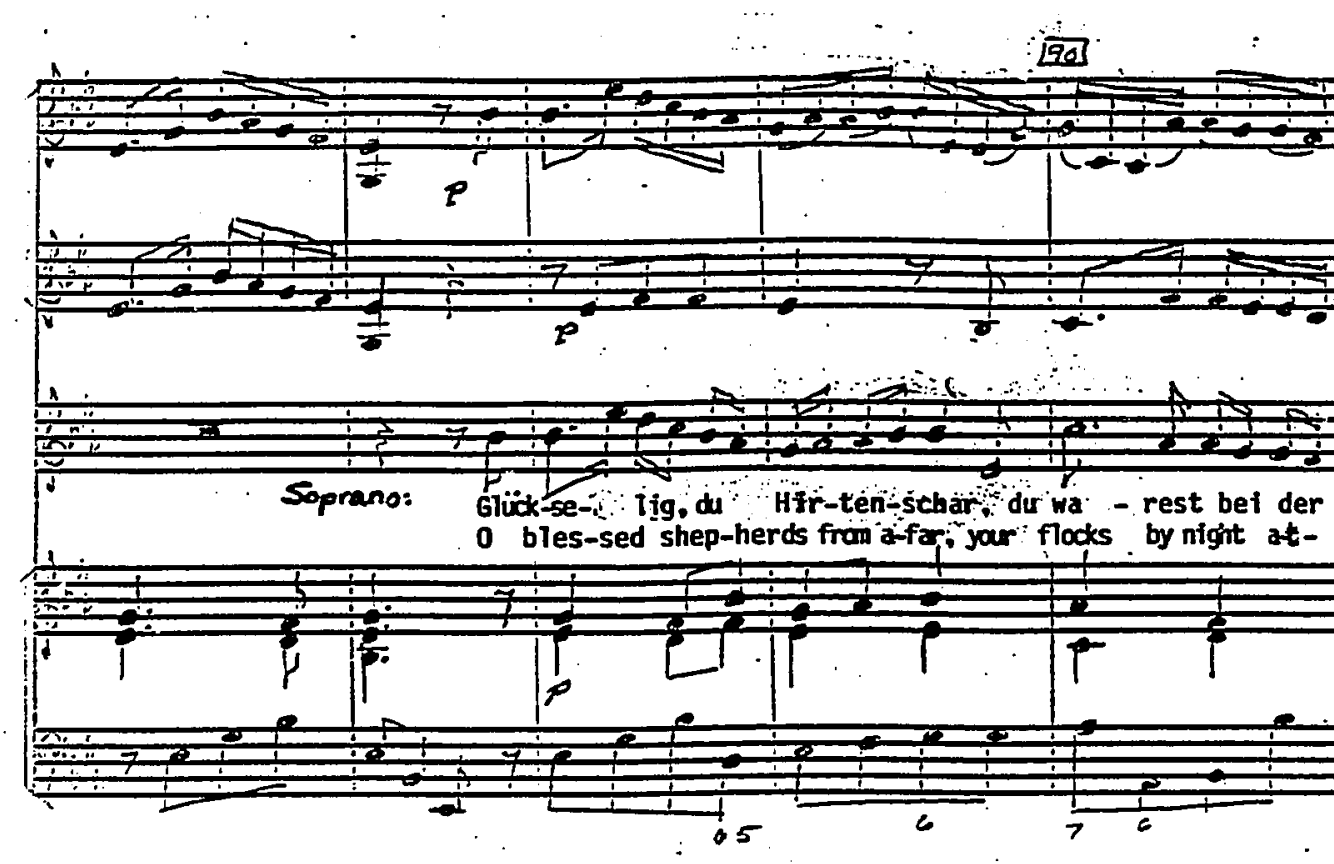

$\Downarrow$

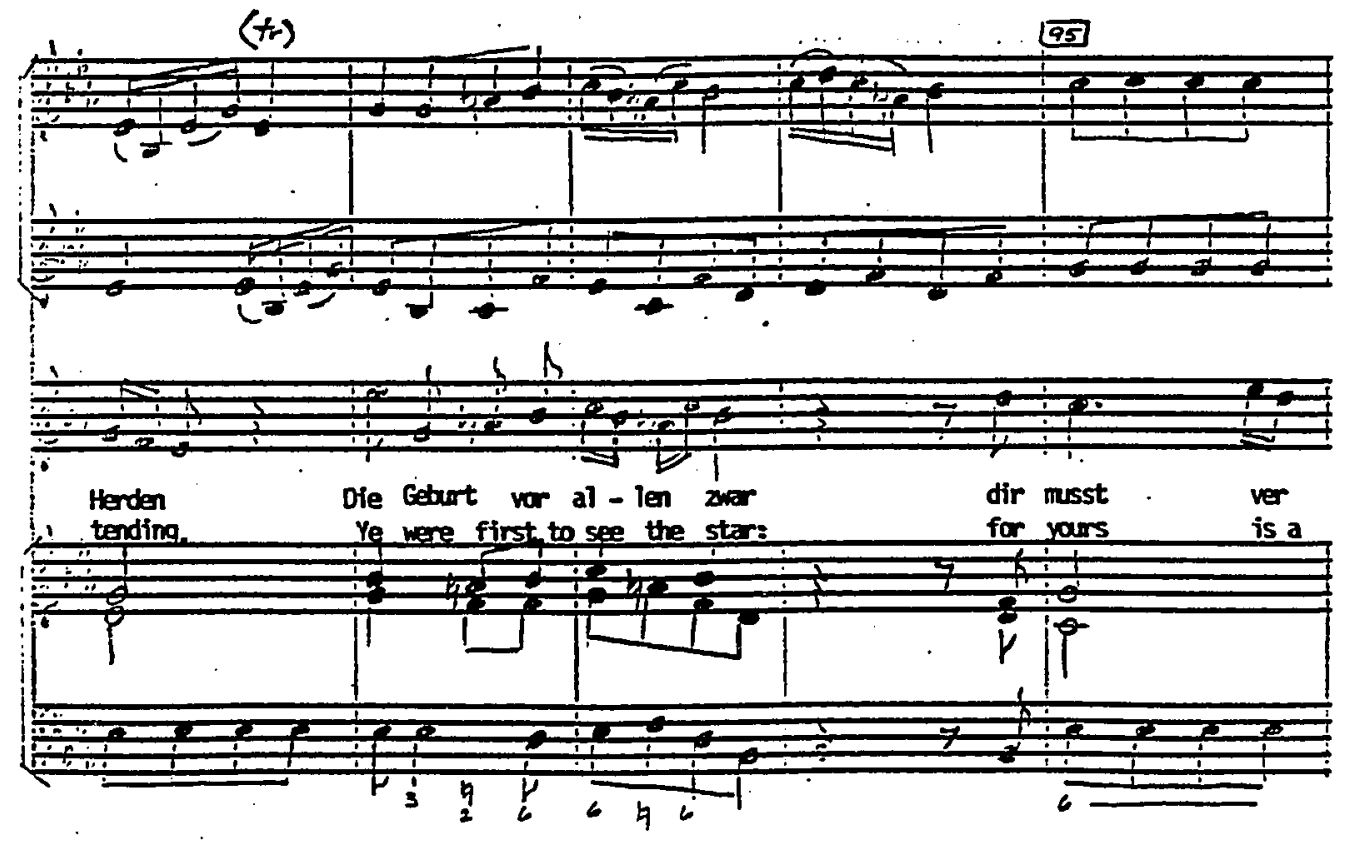




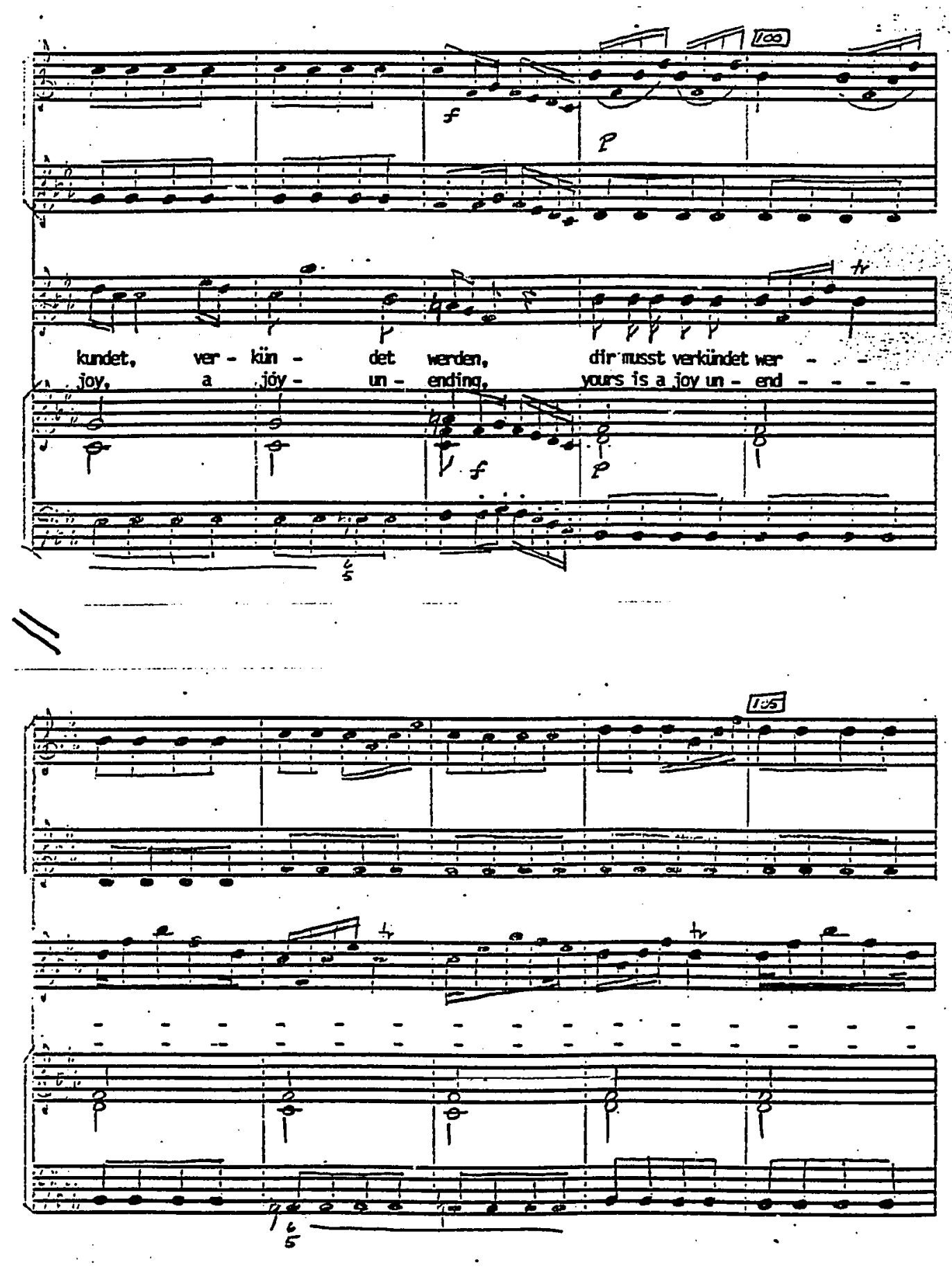




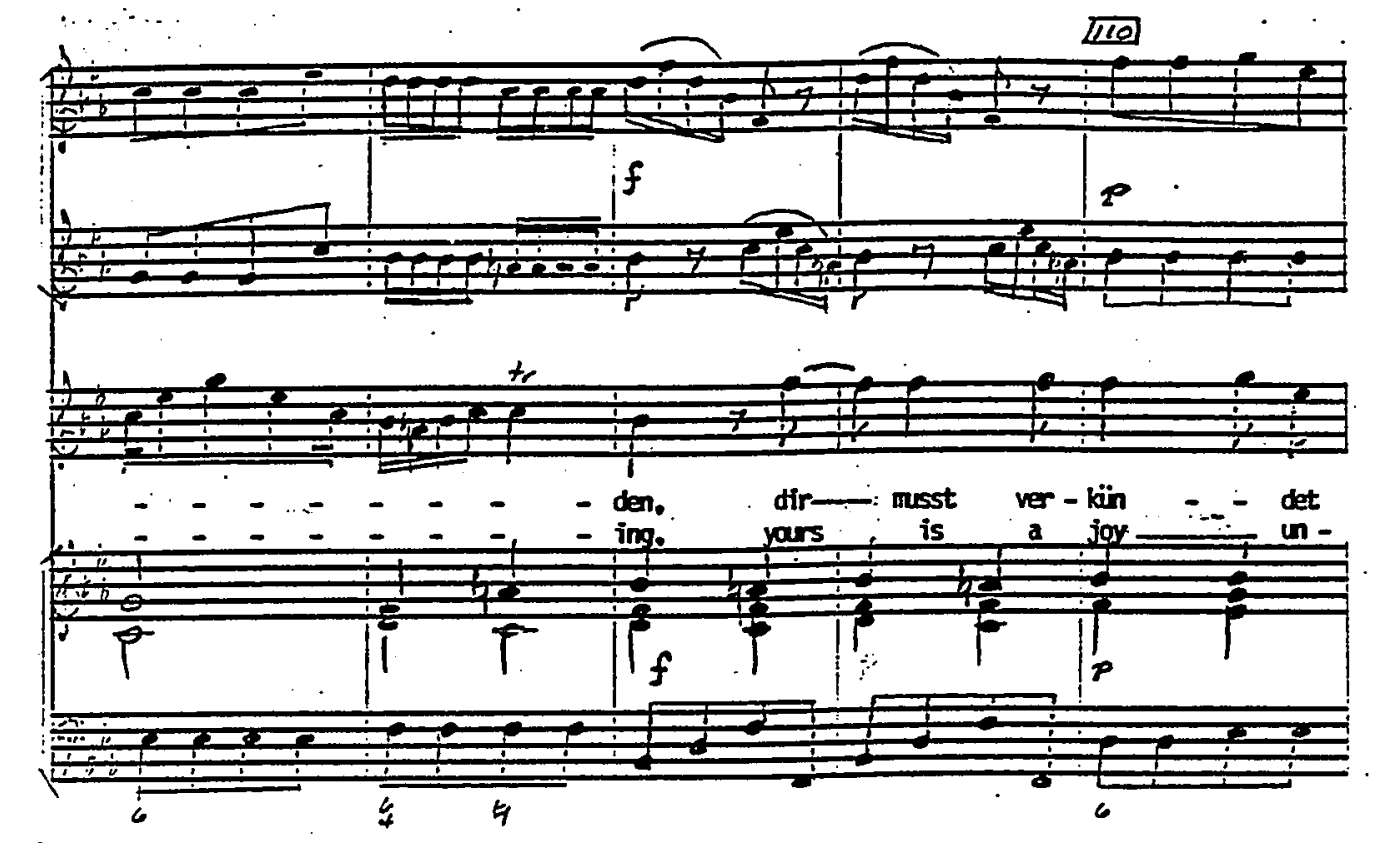

$\$$
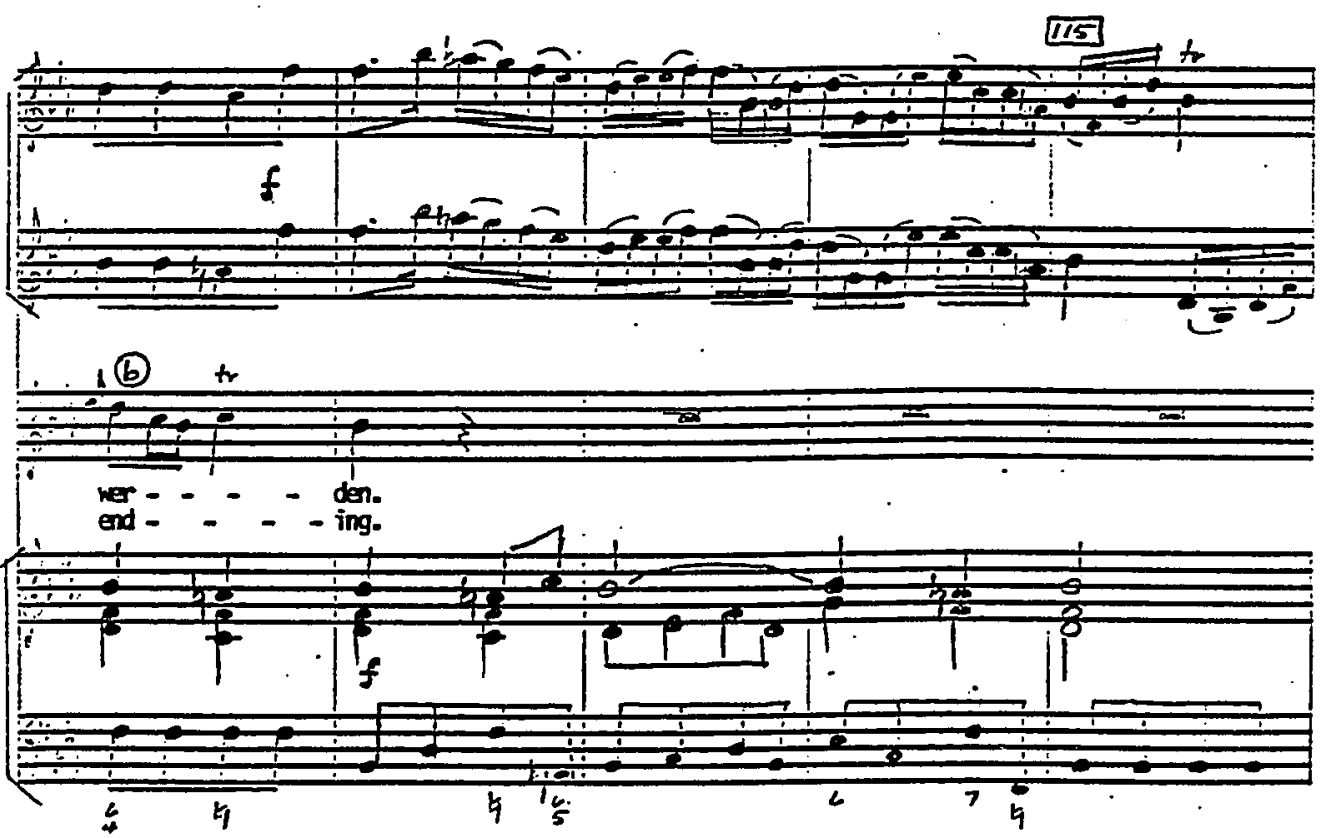

6
+219 


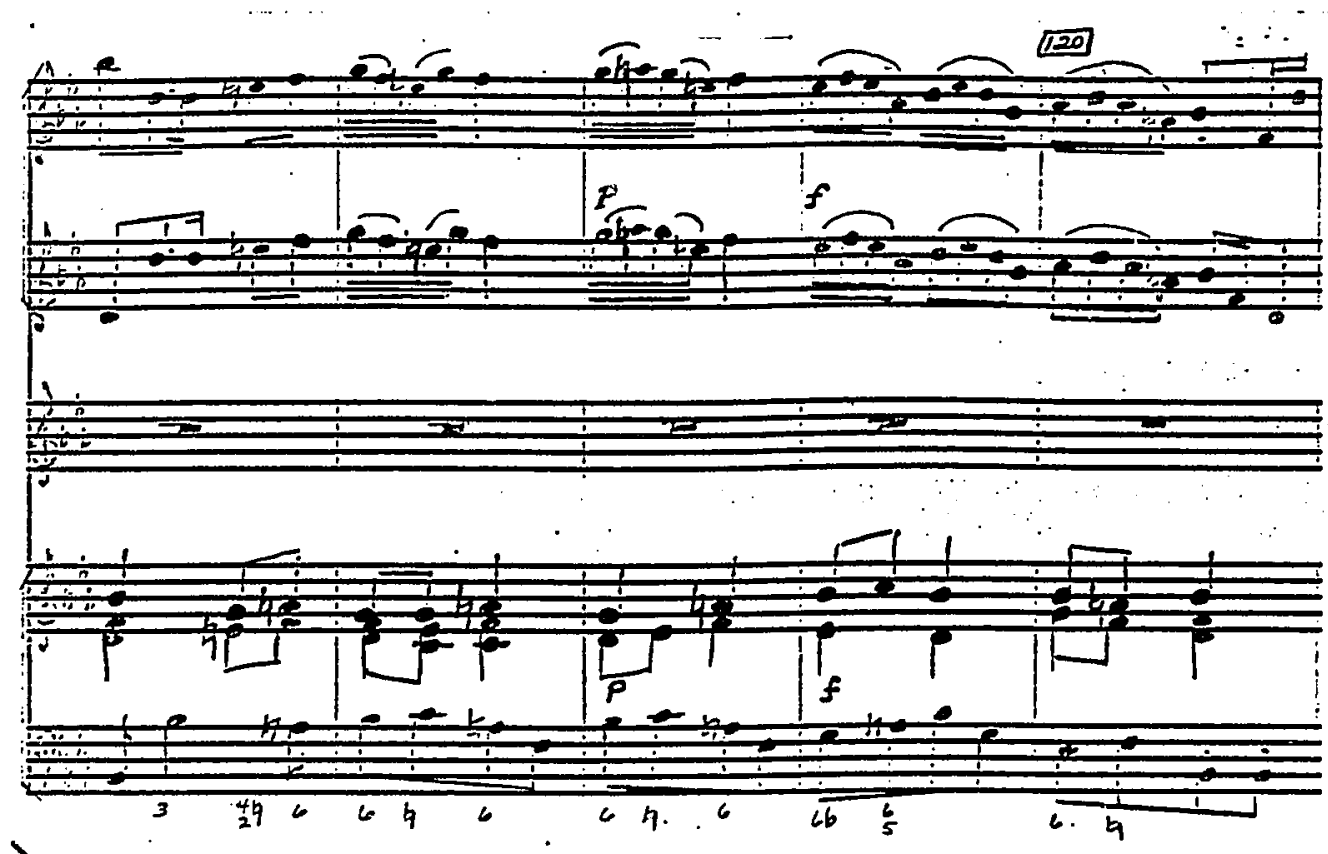

1

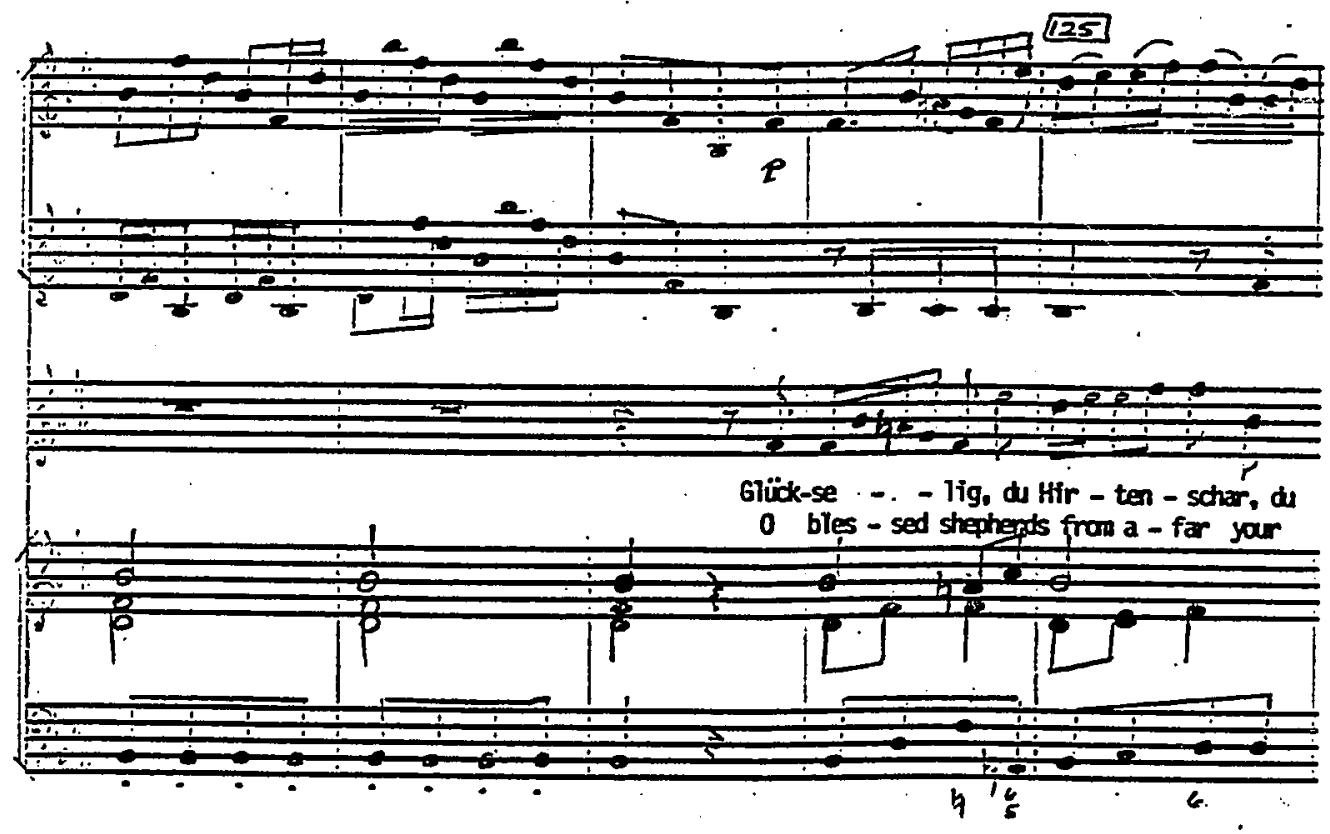



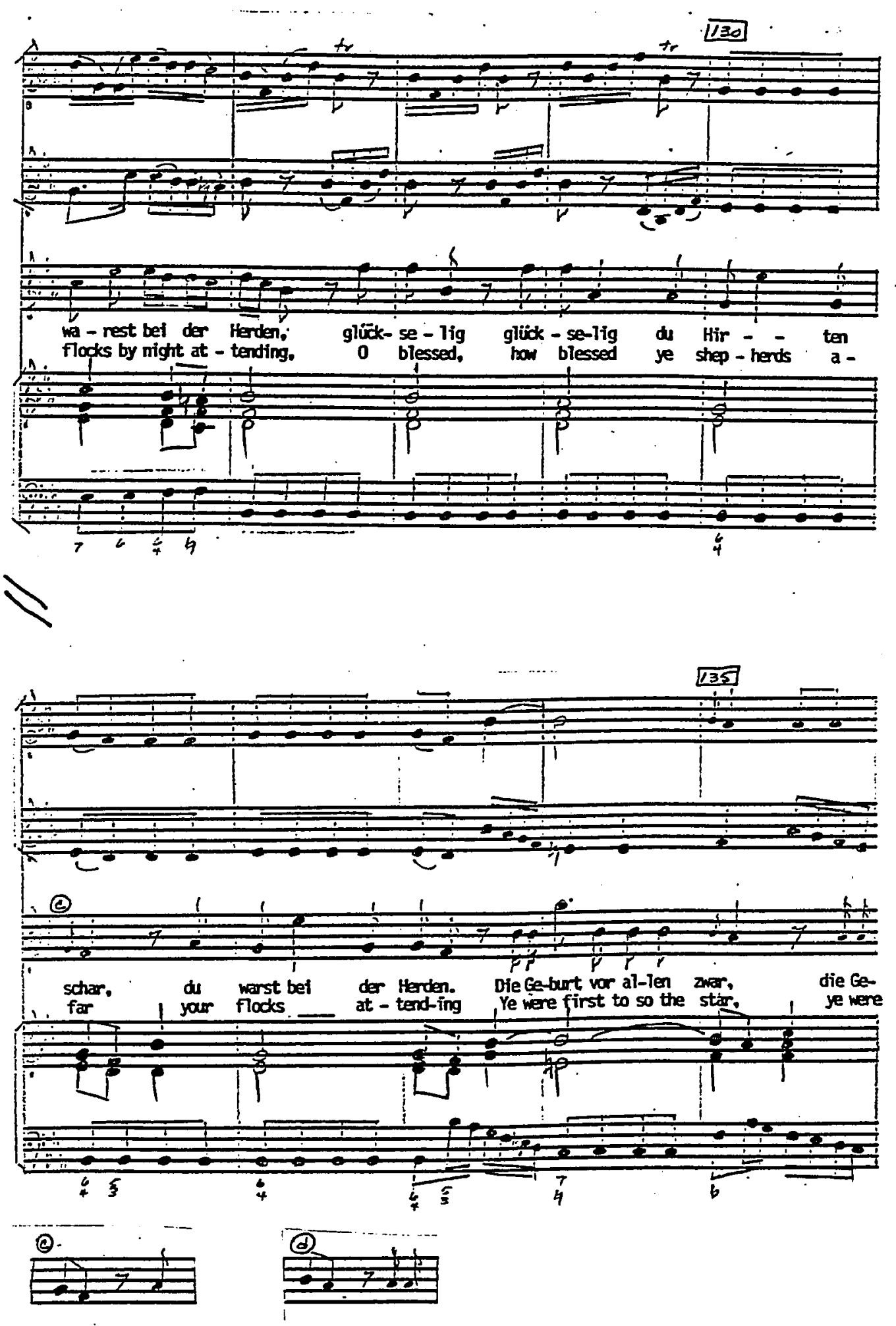


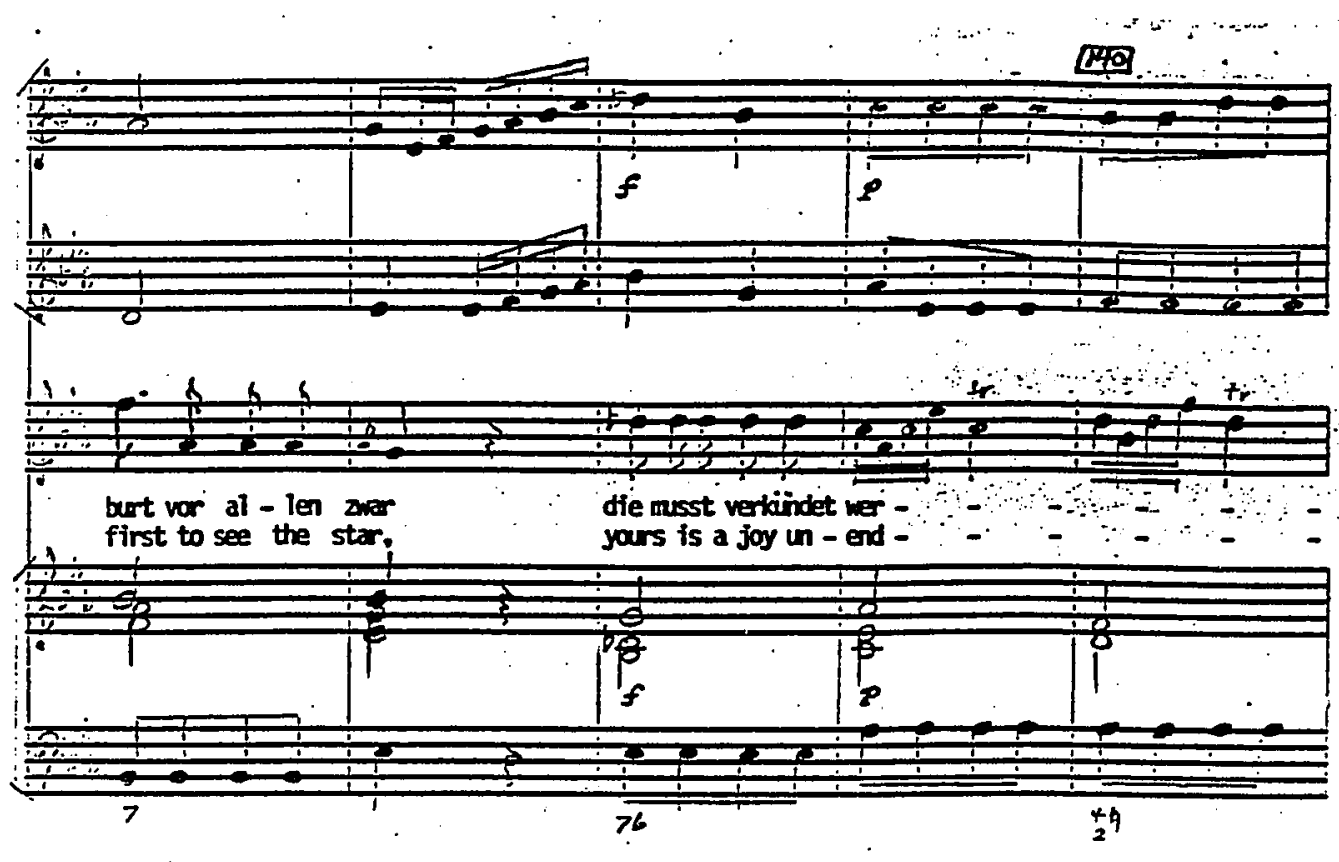

$\$$
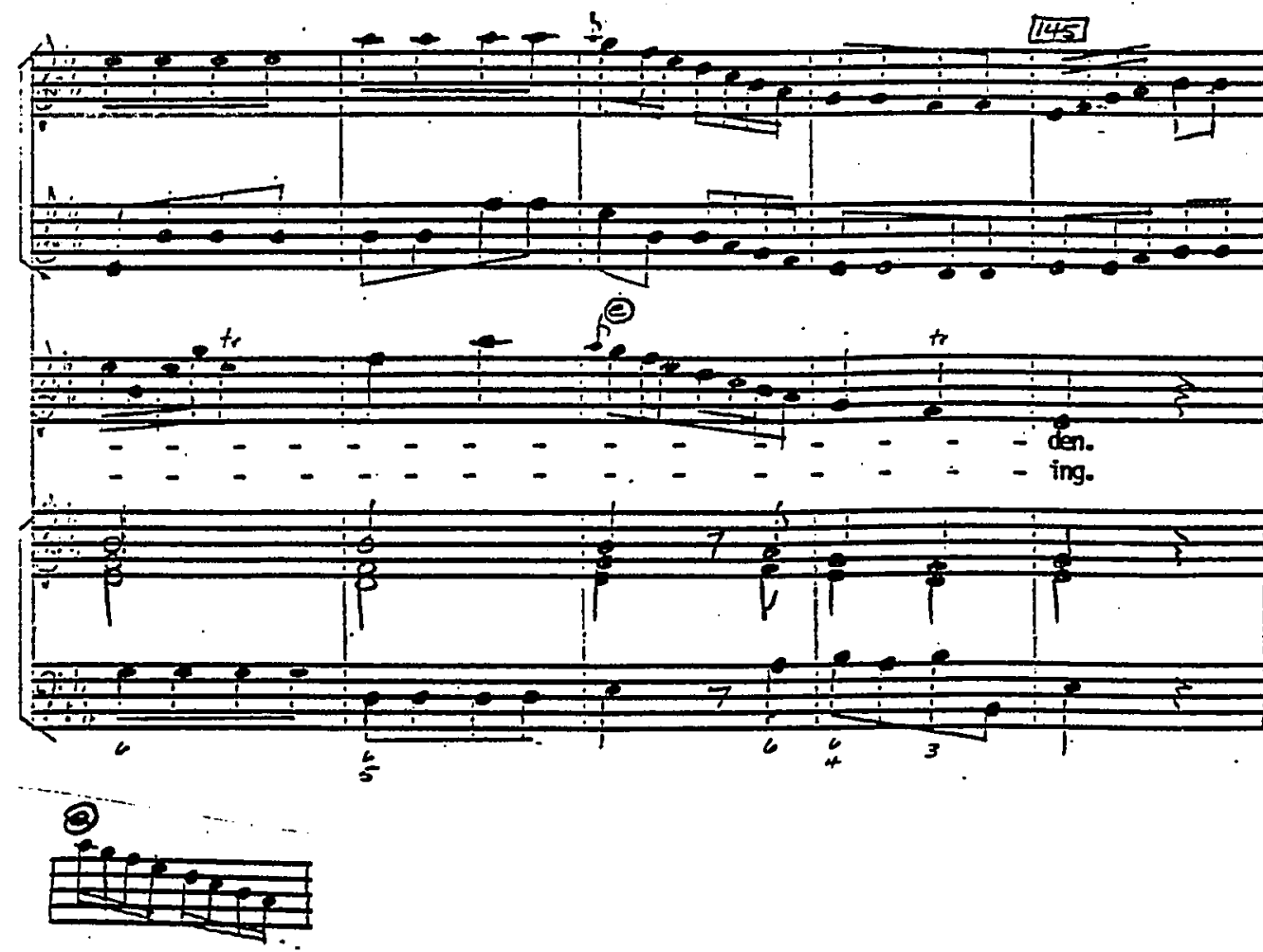

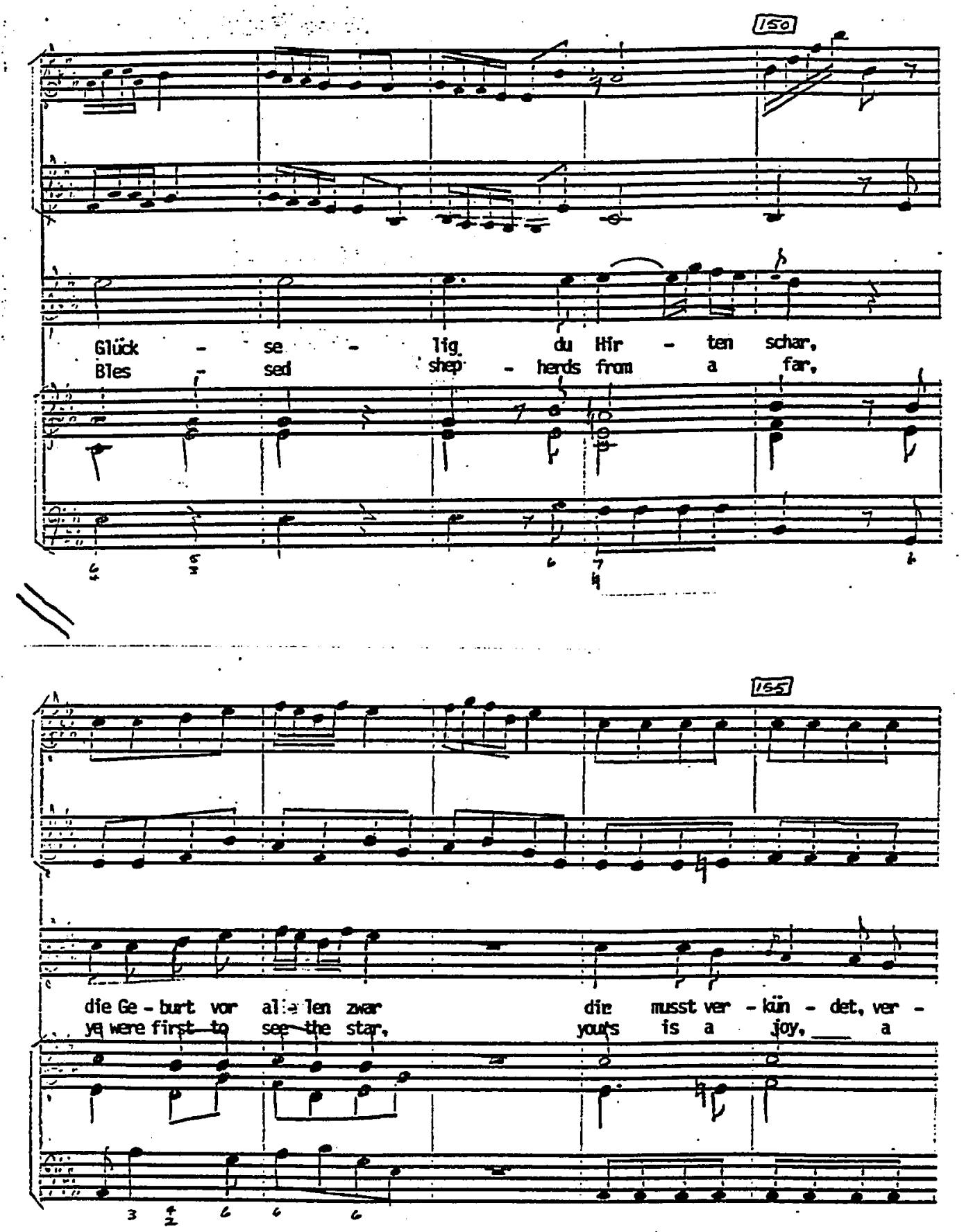

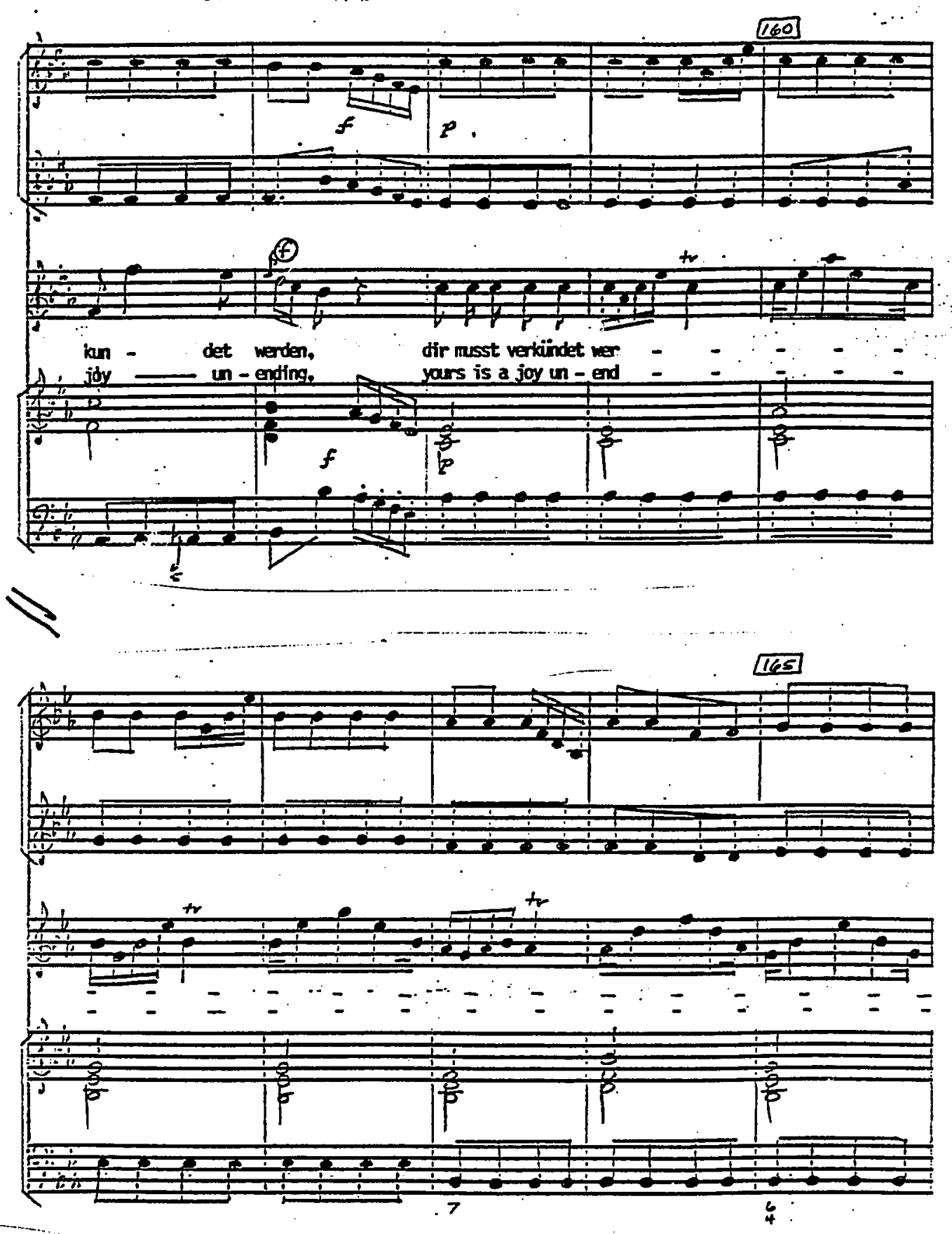

$\oplus$

Eक 


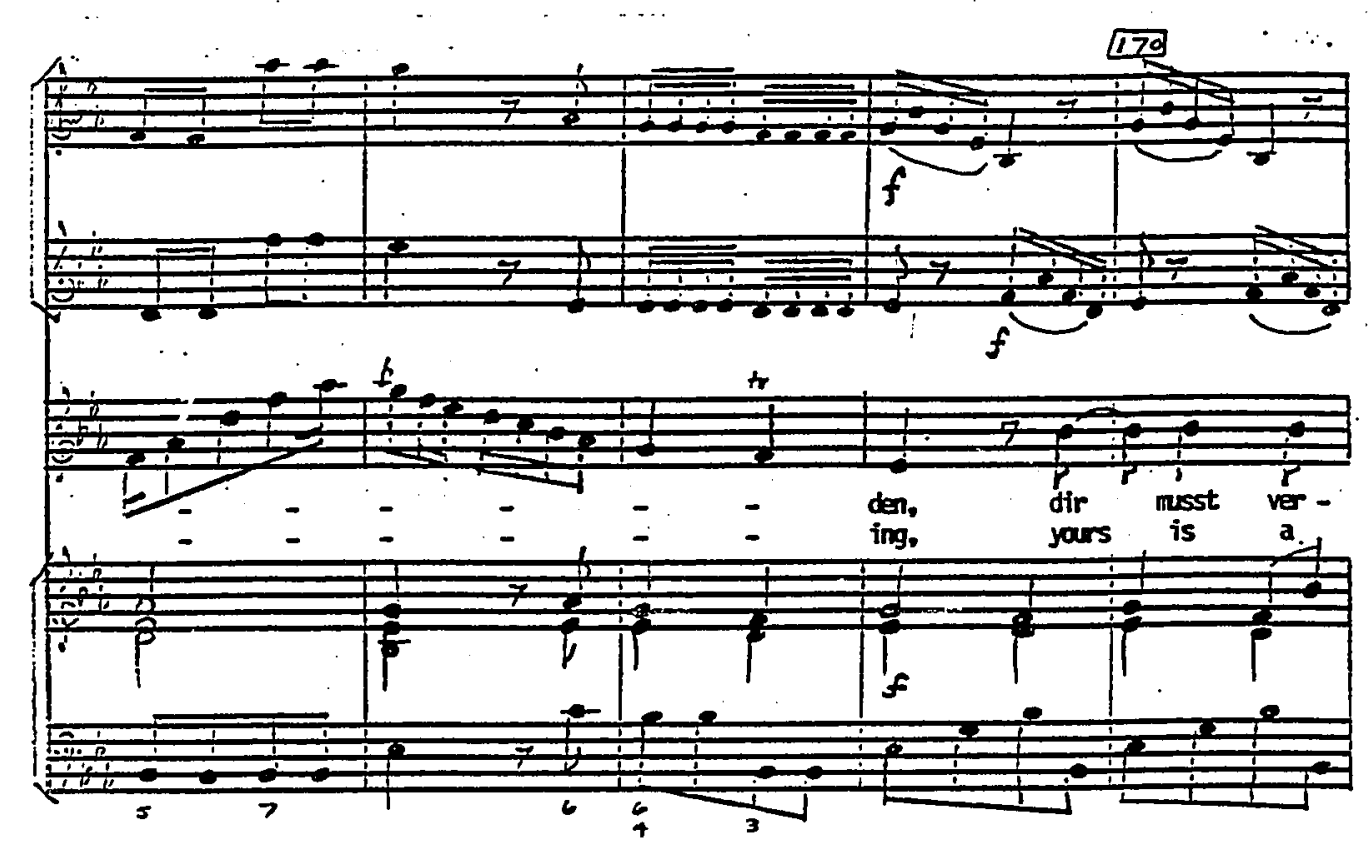

$\searrow$

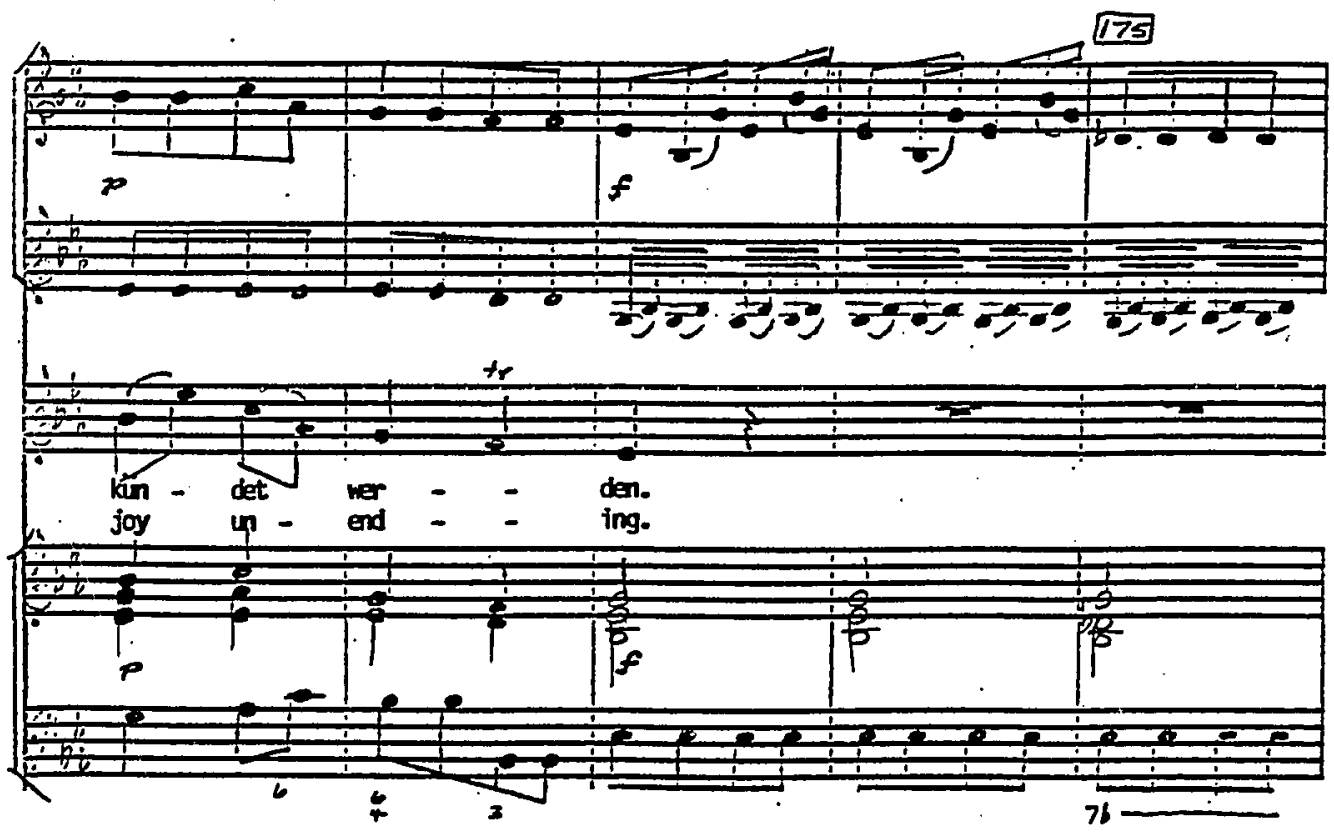




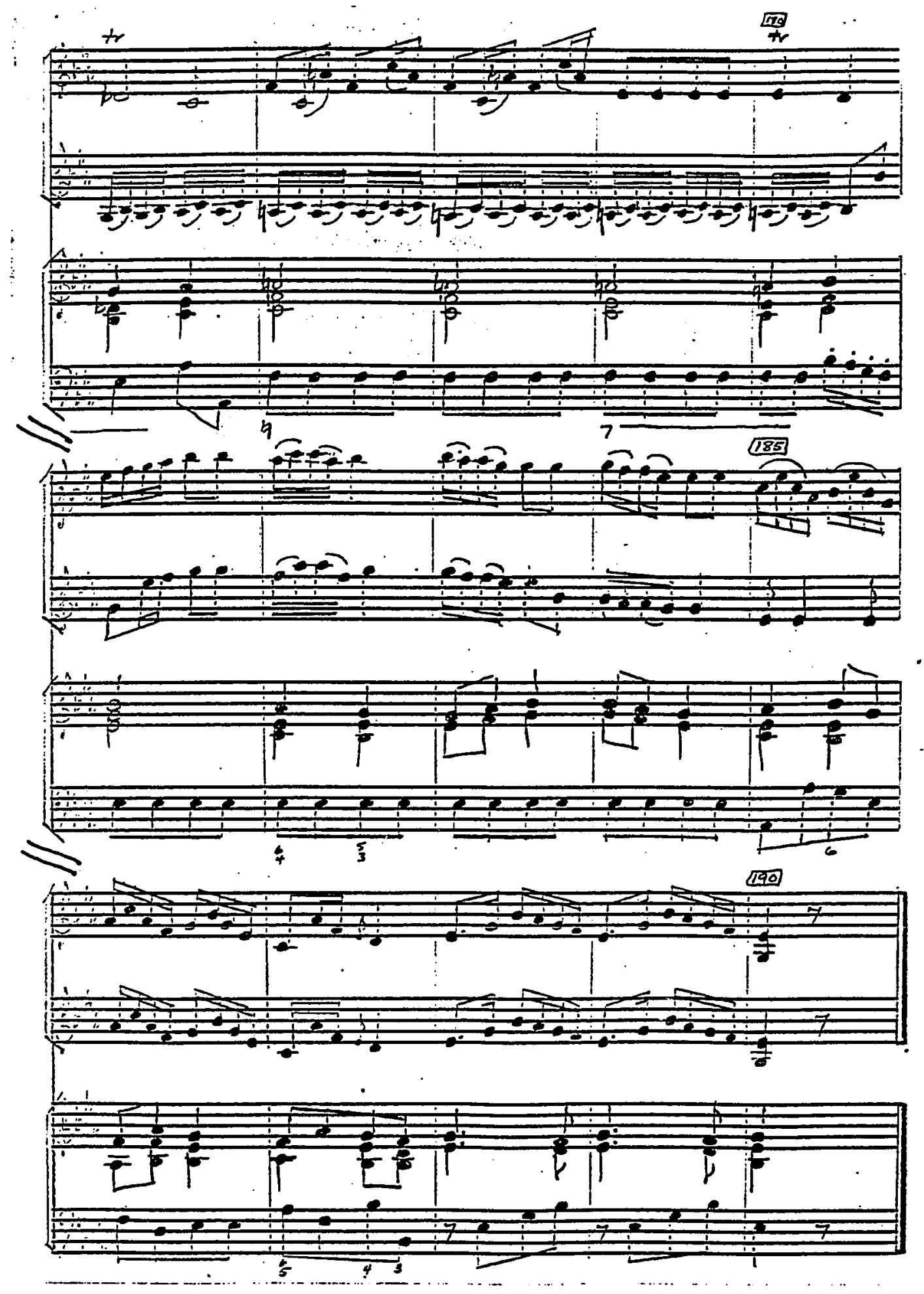



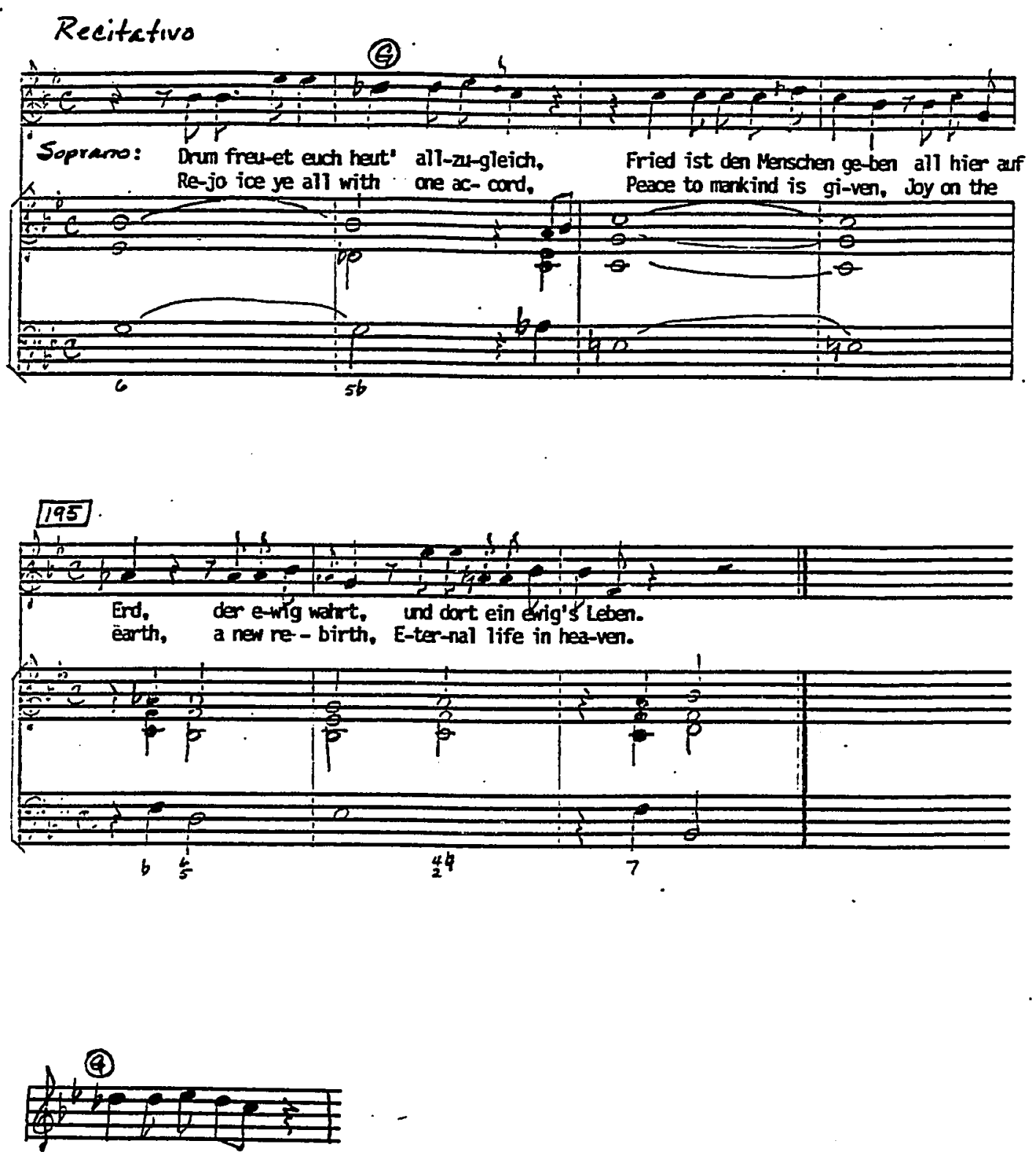


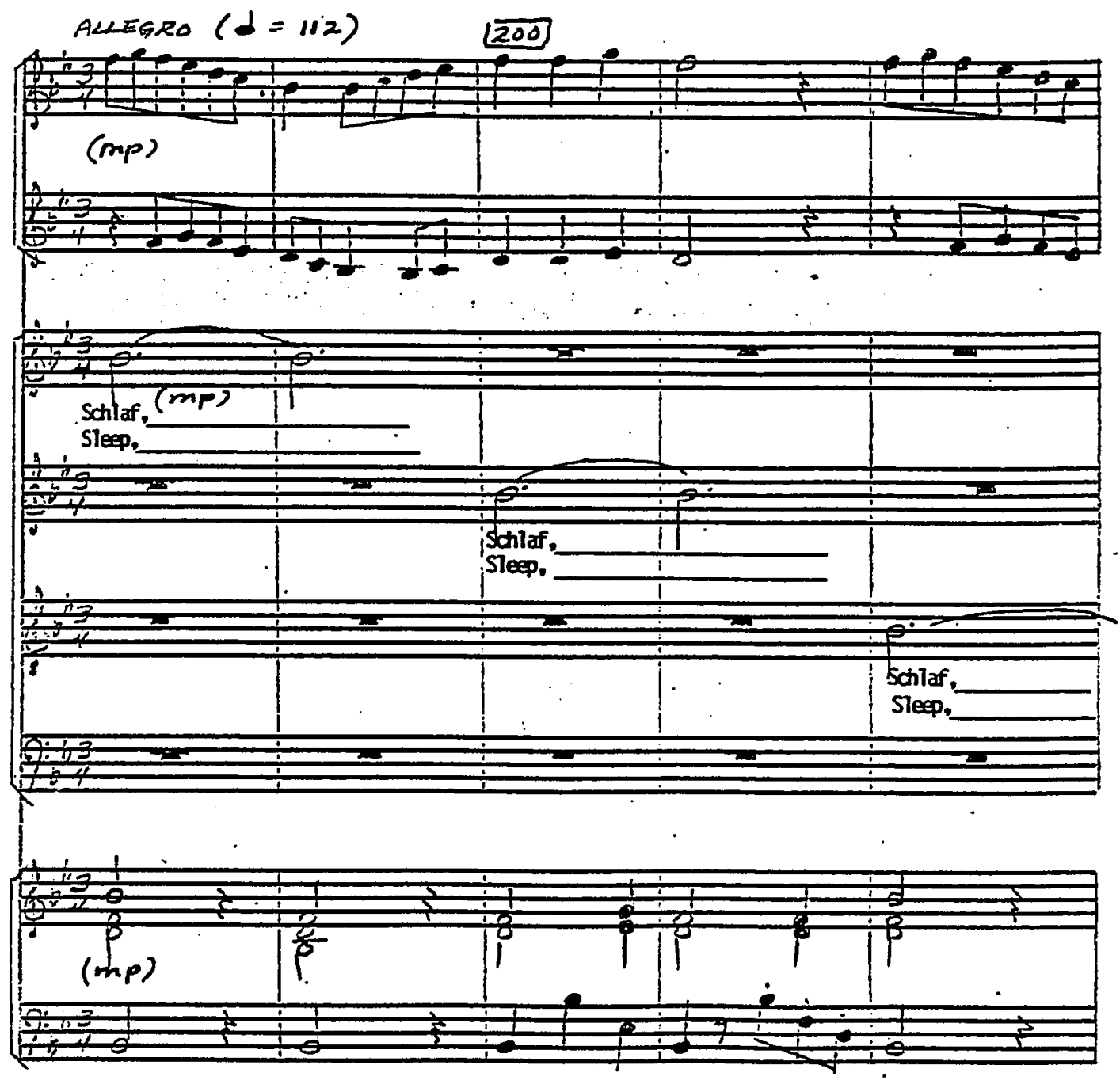




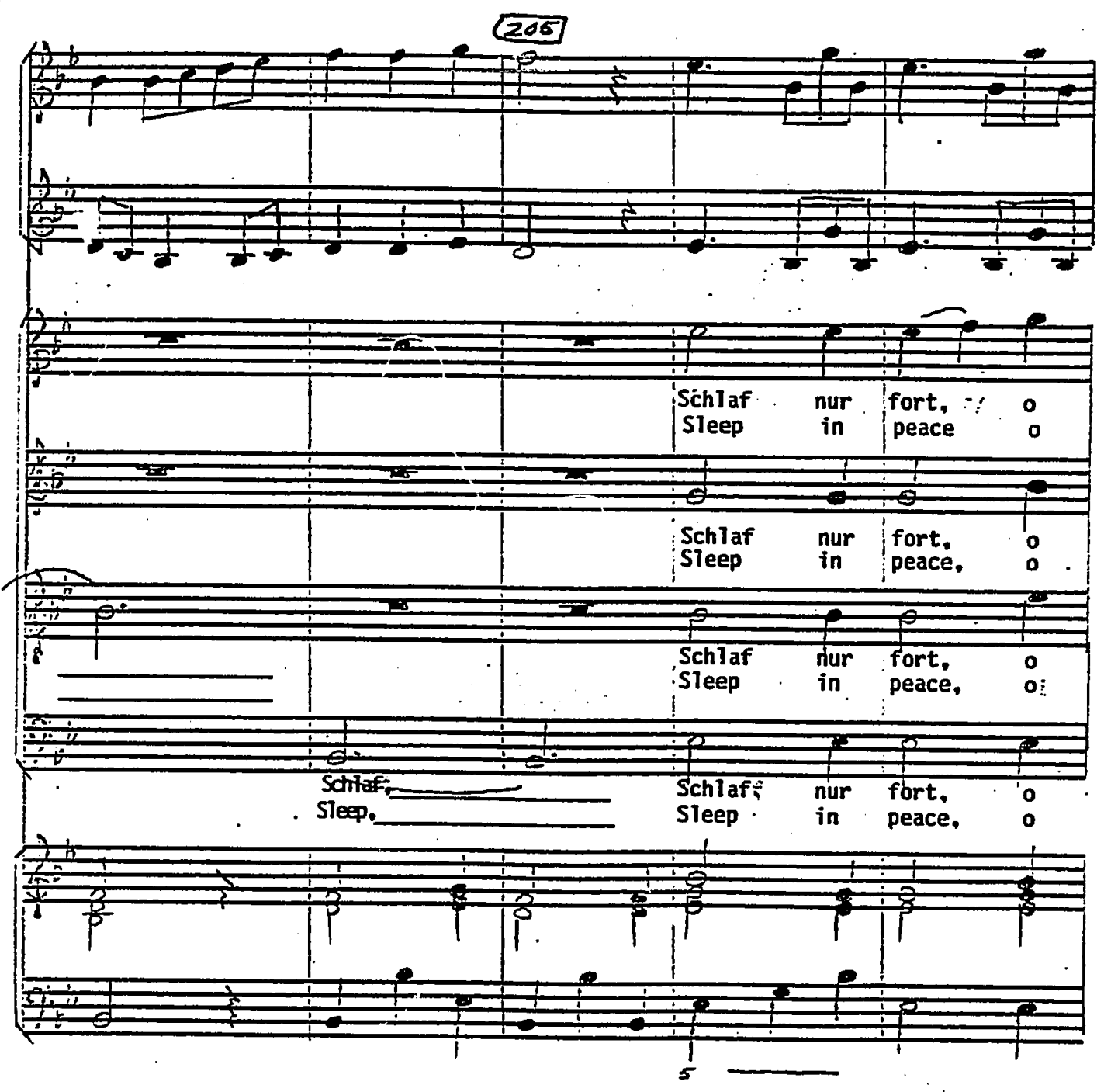




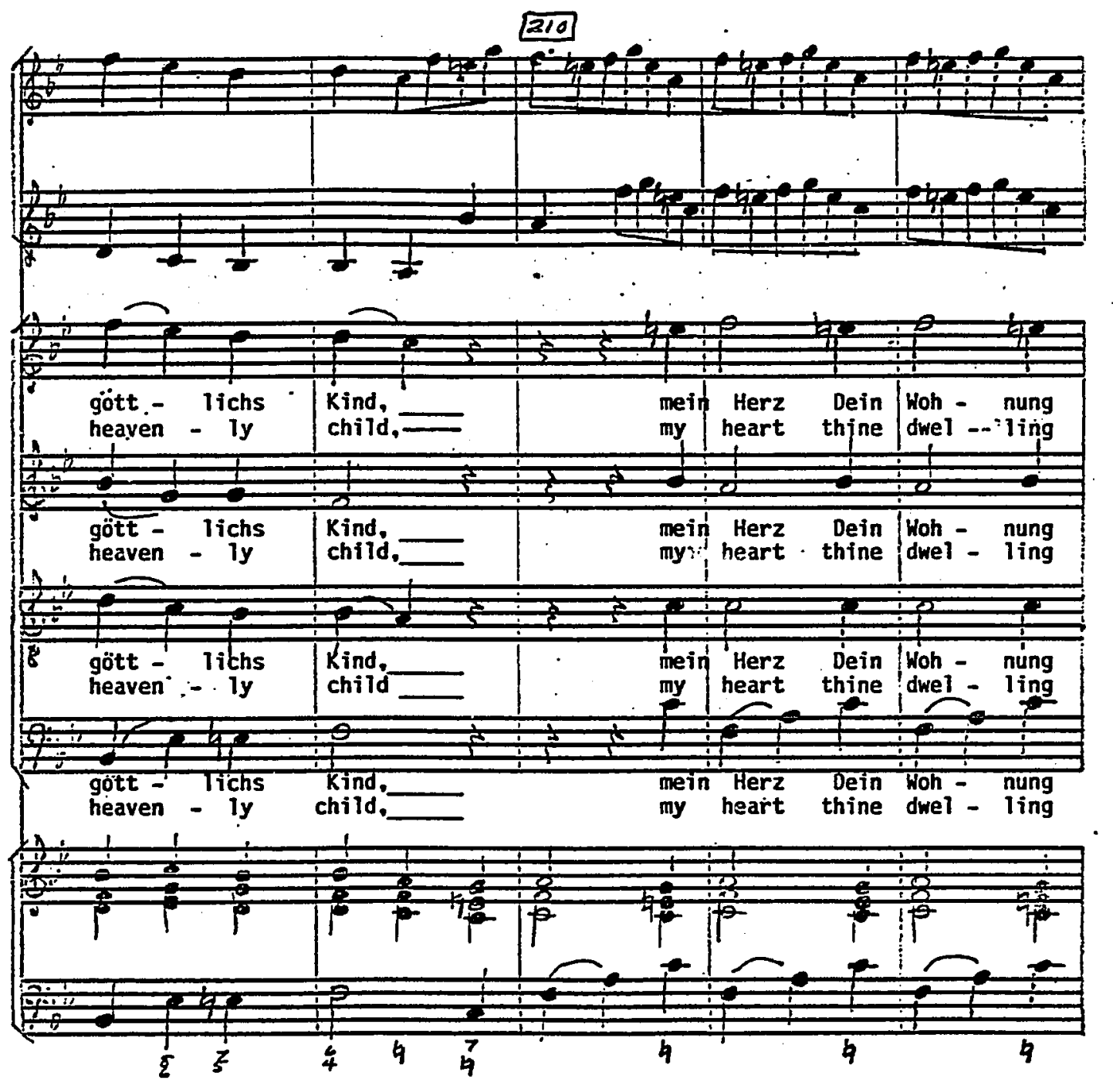




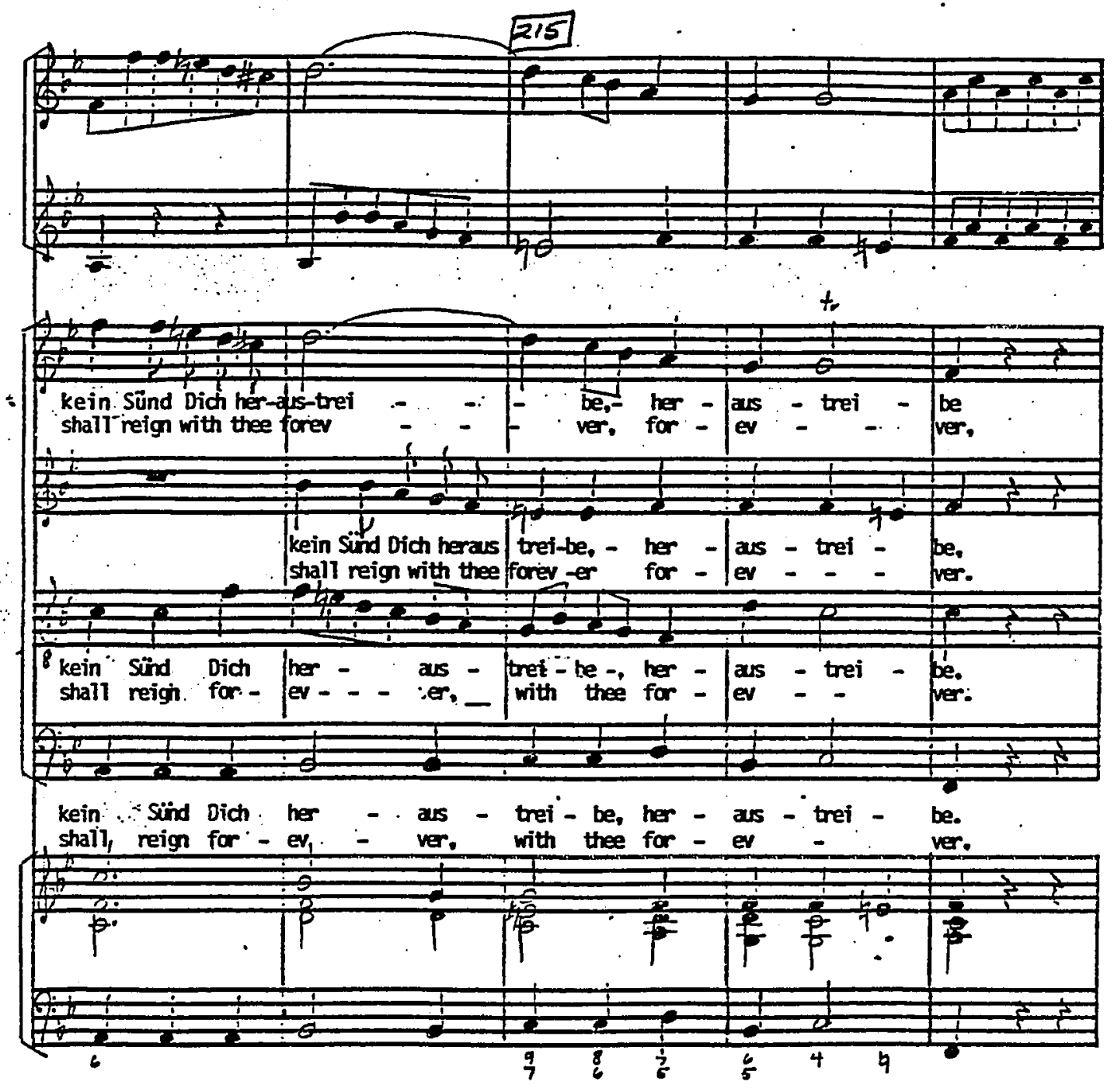




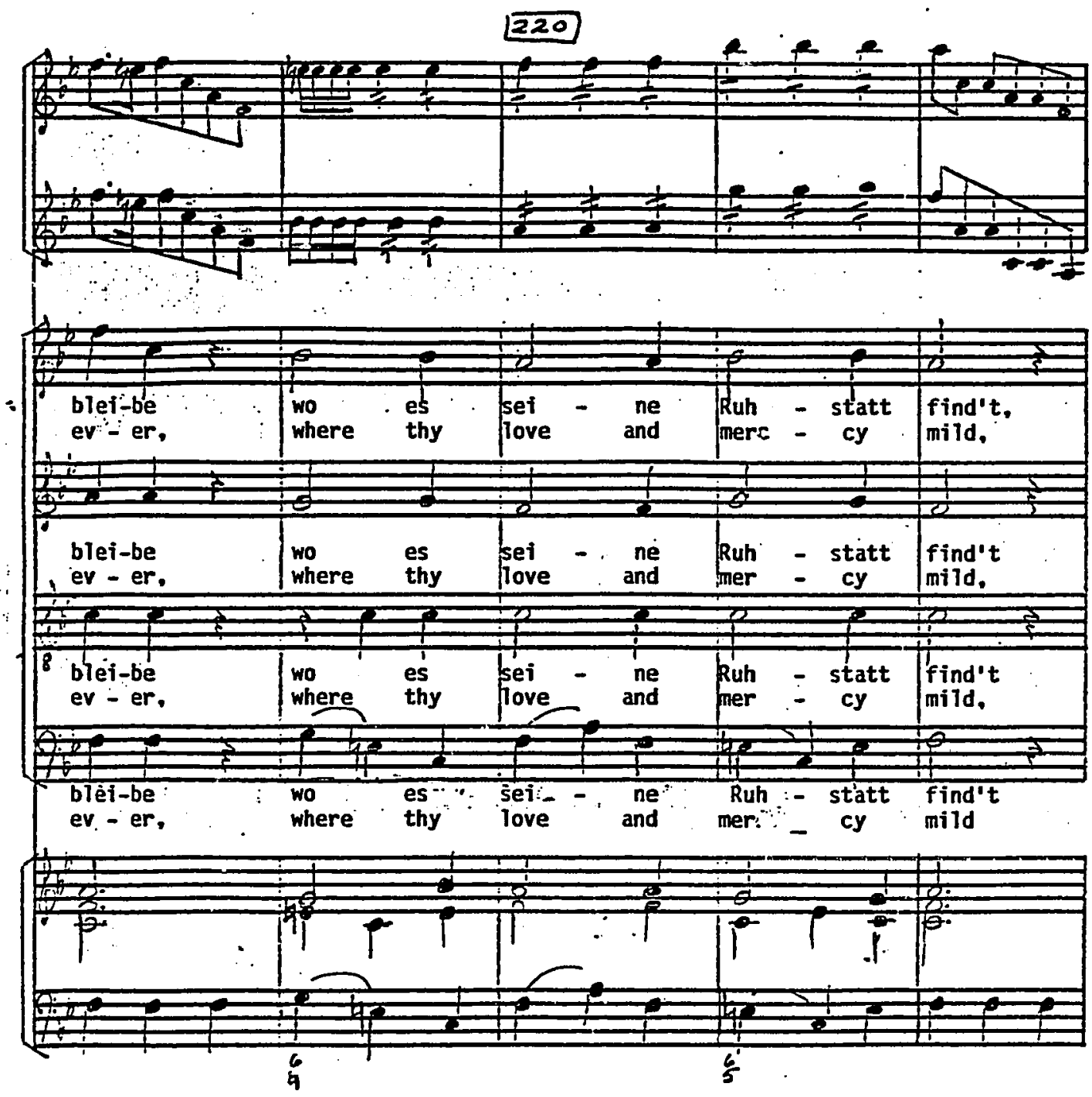




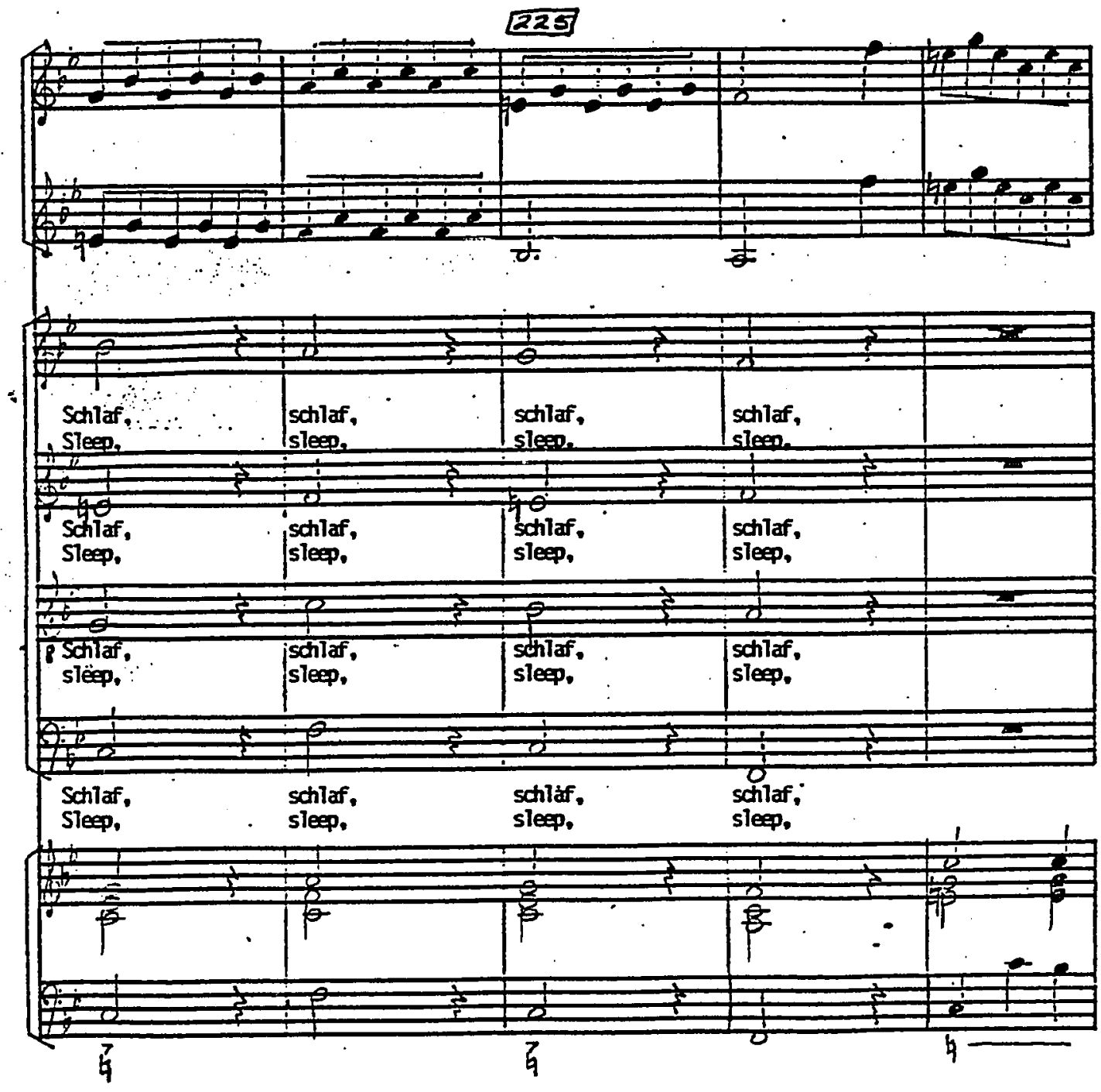




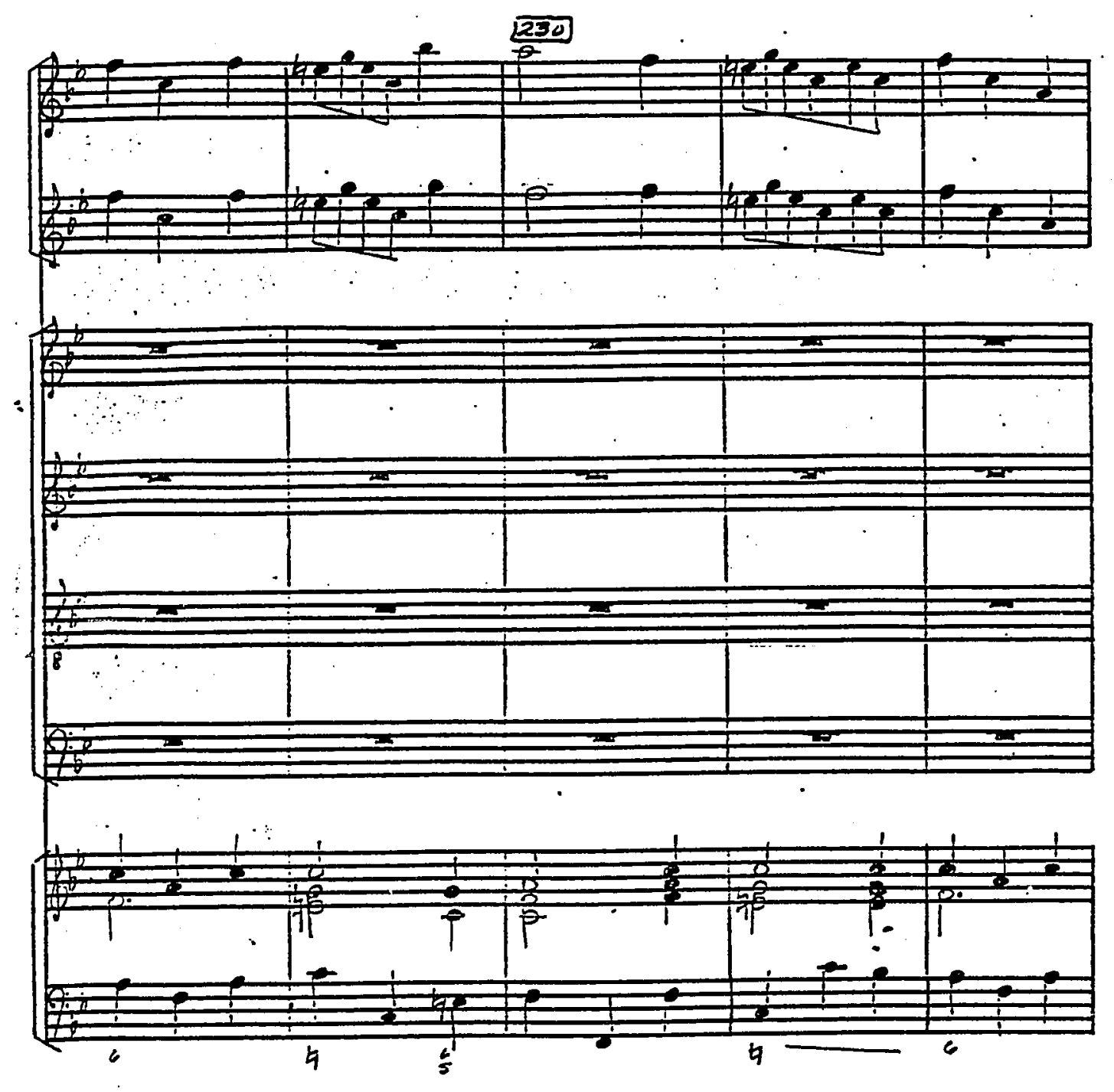




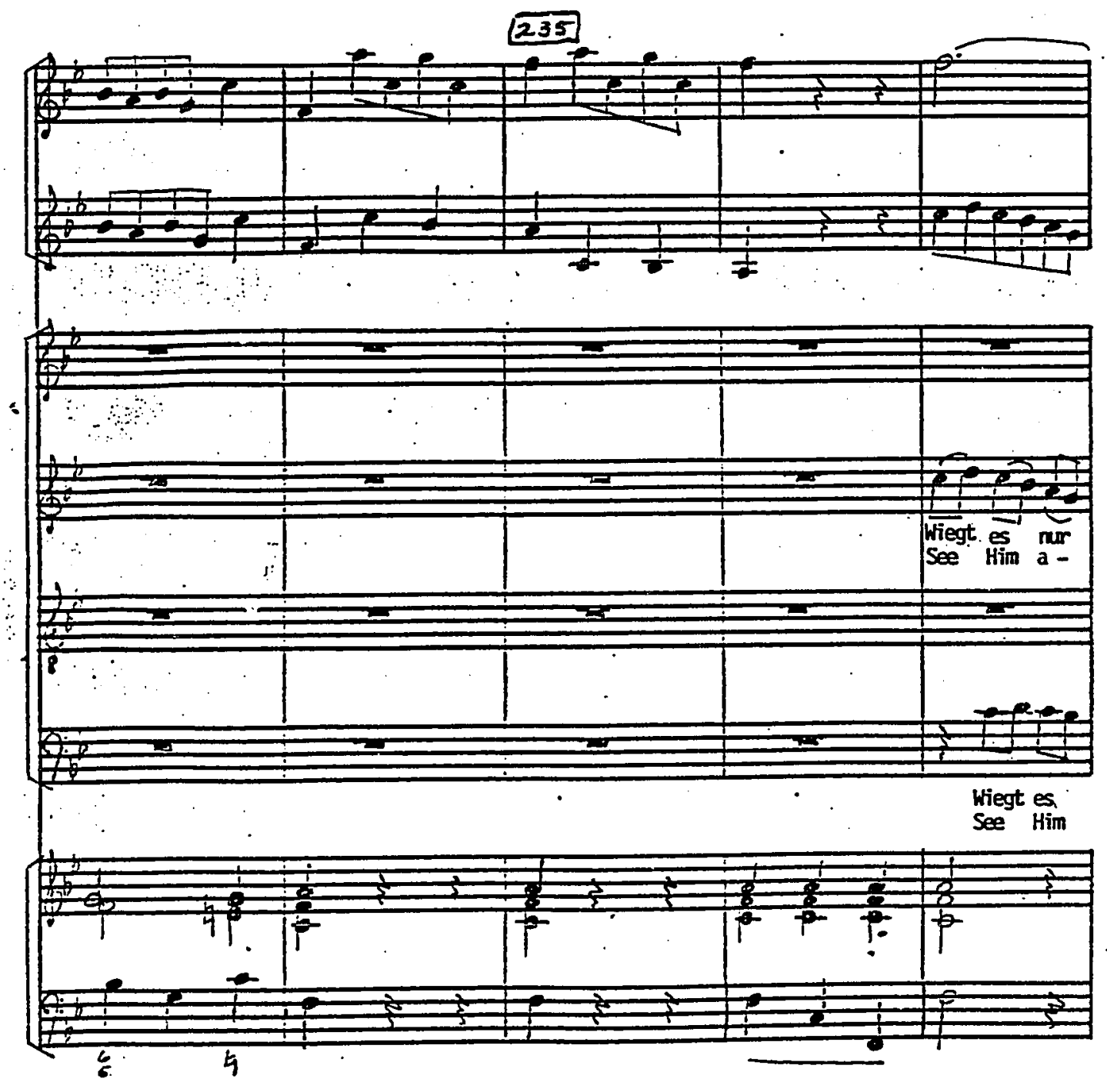




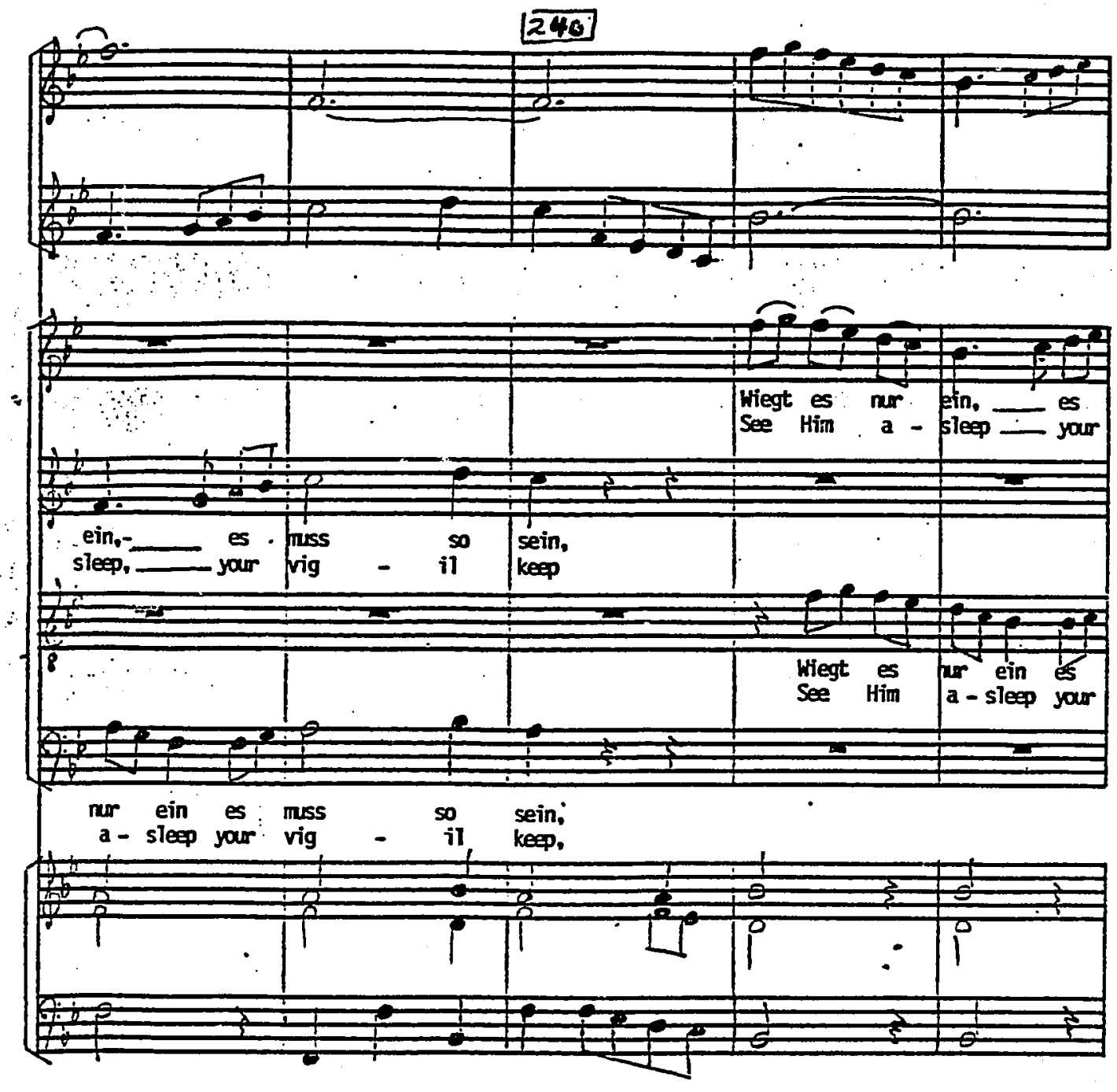




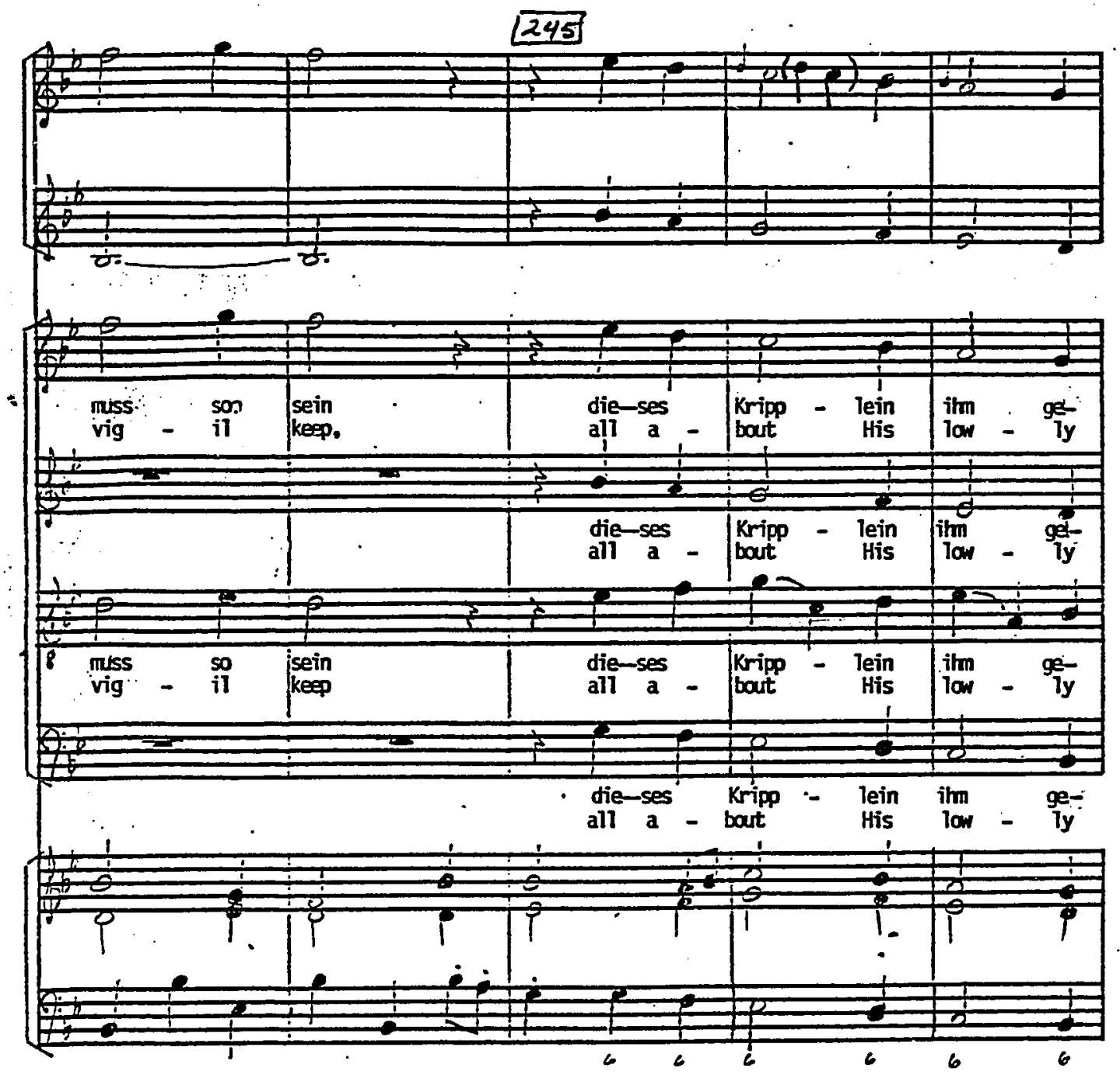




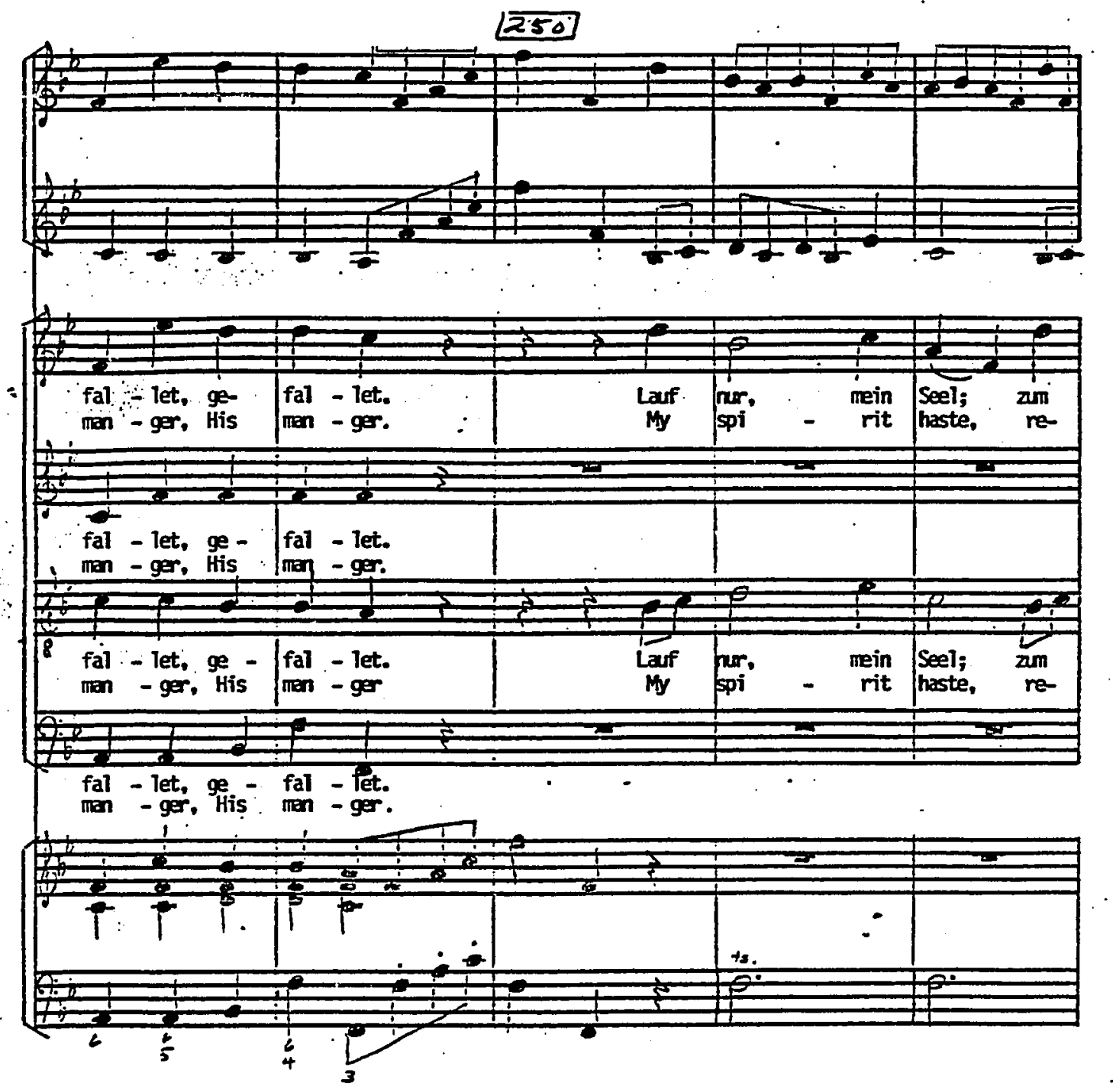




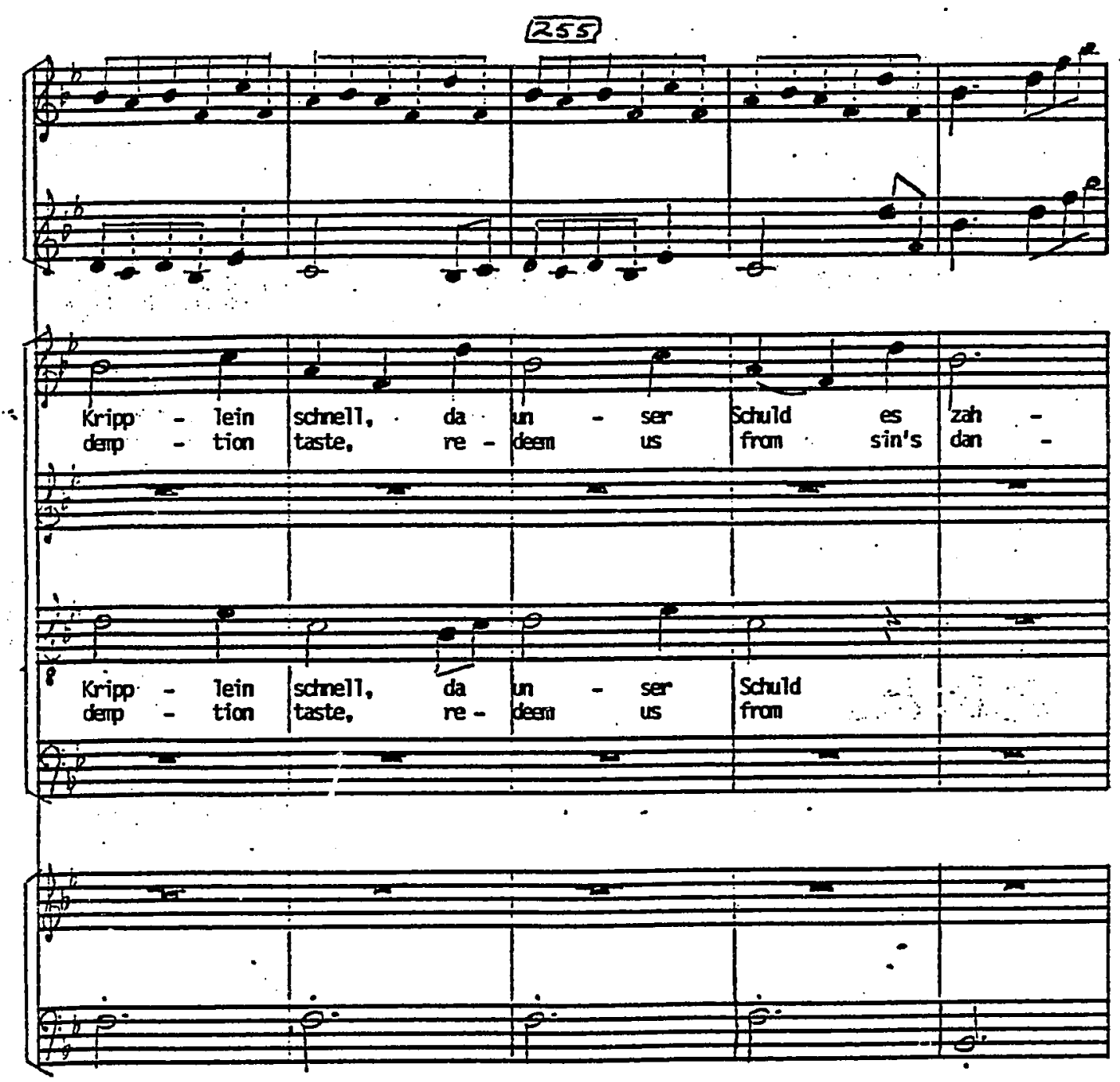




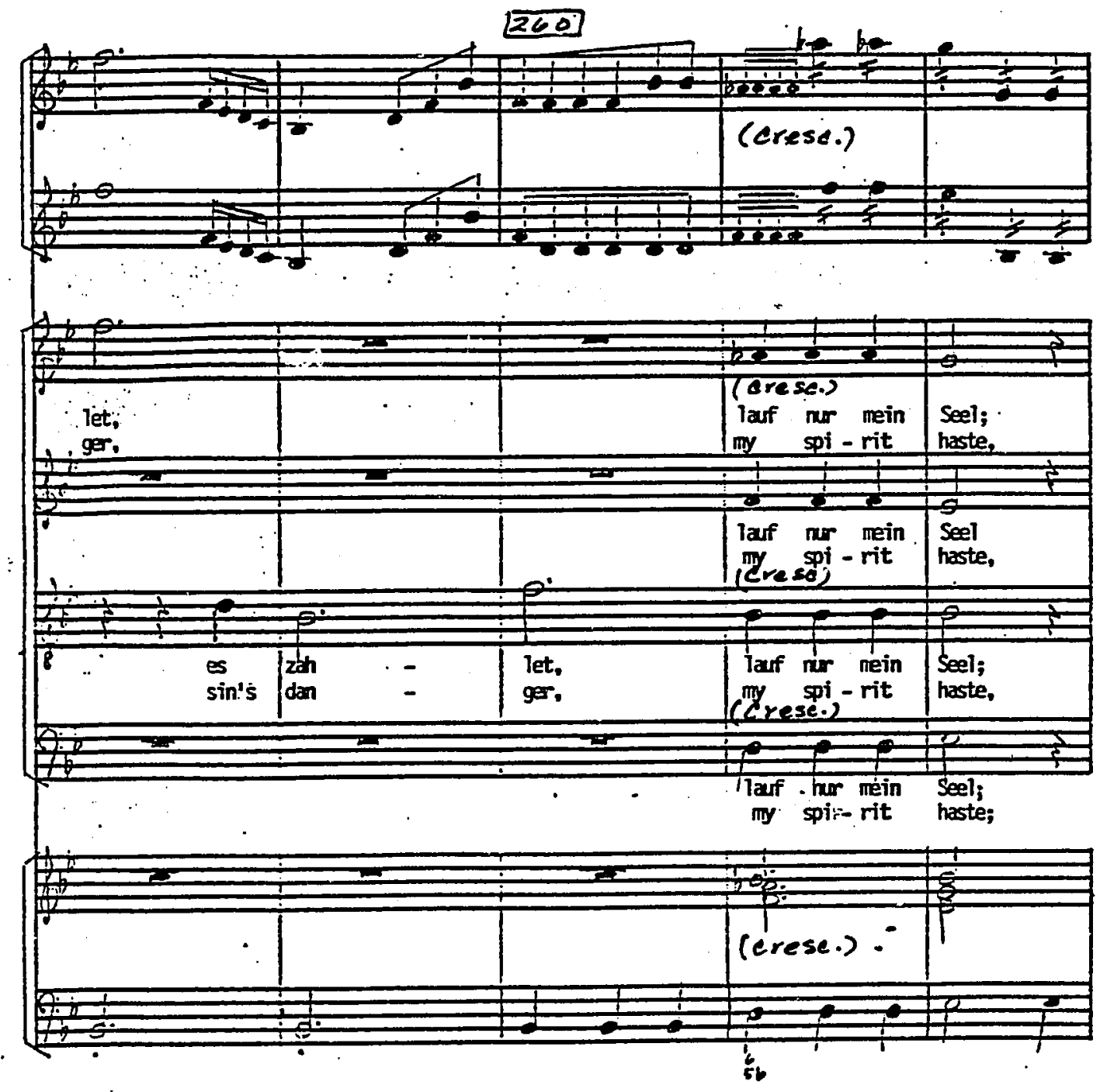




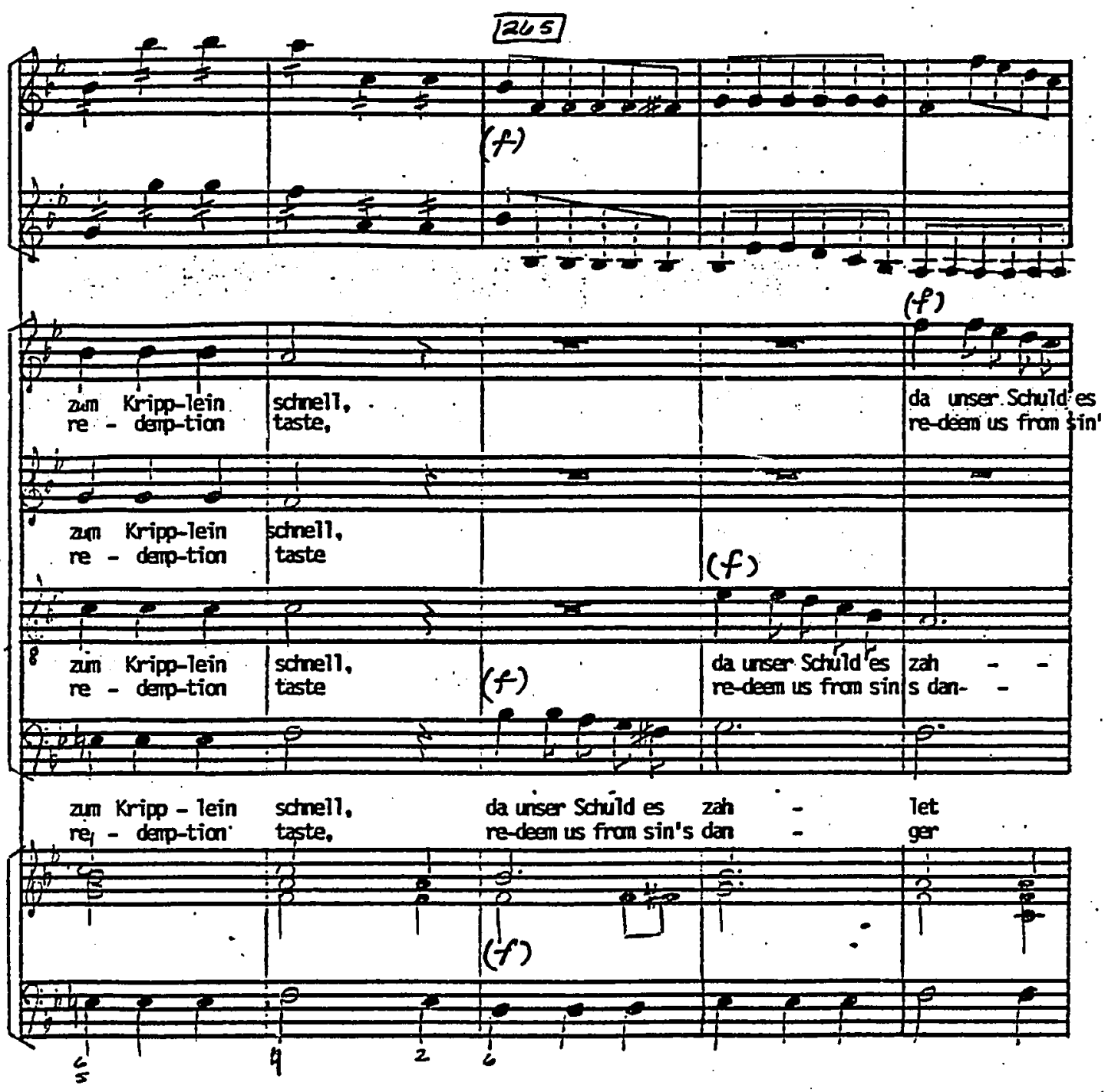




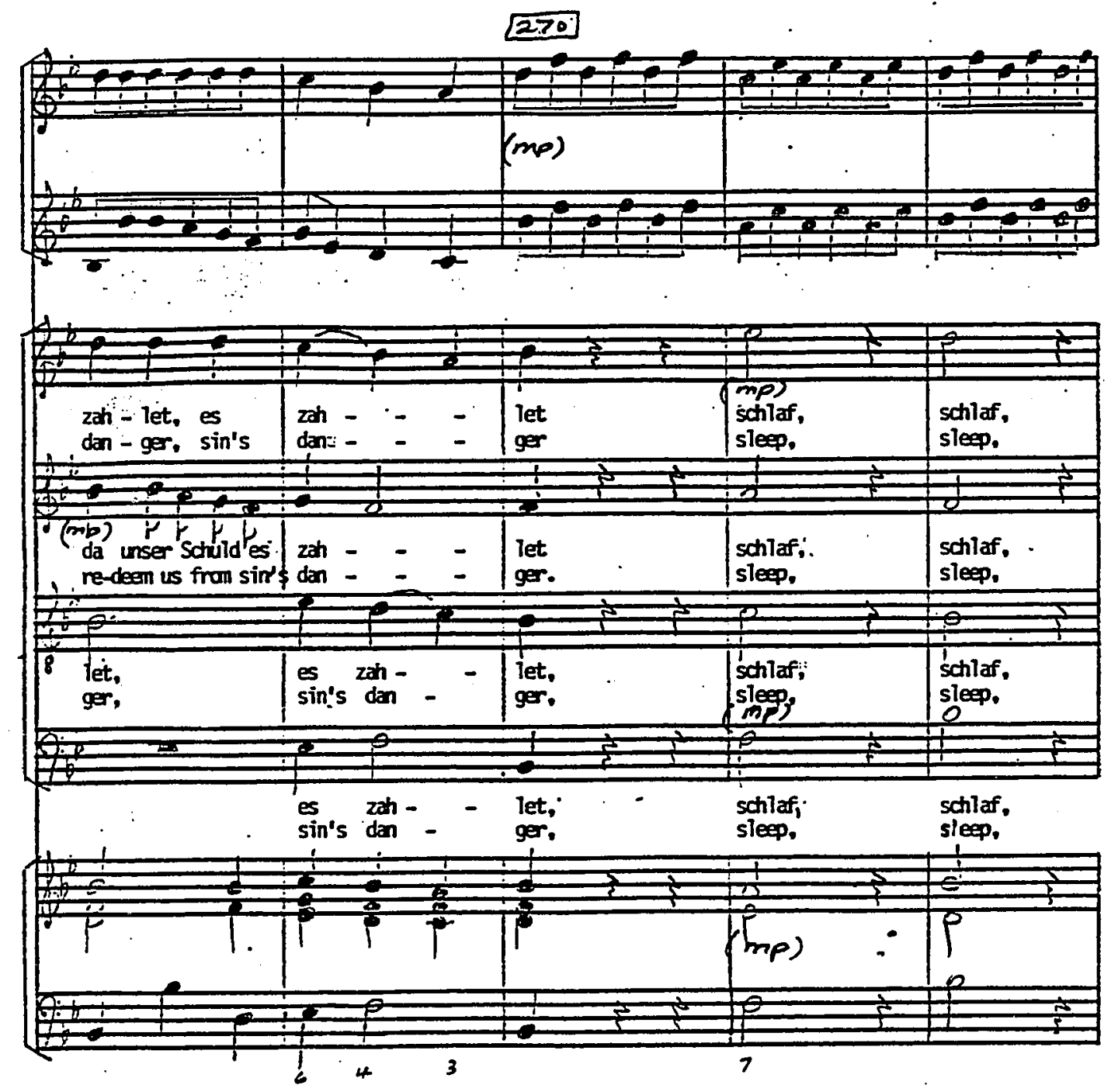




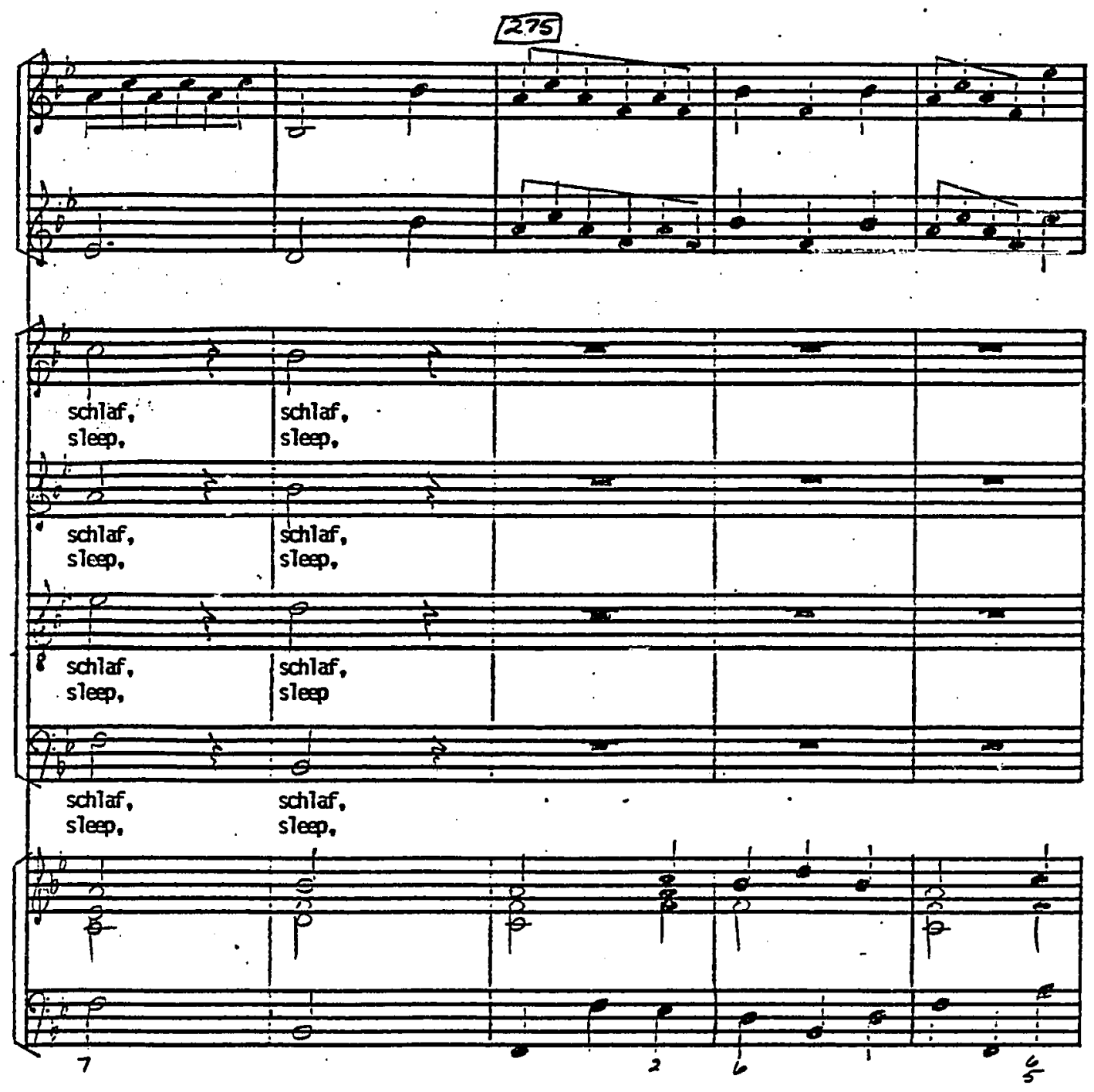




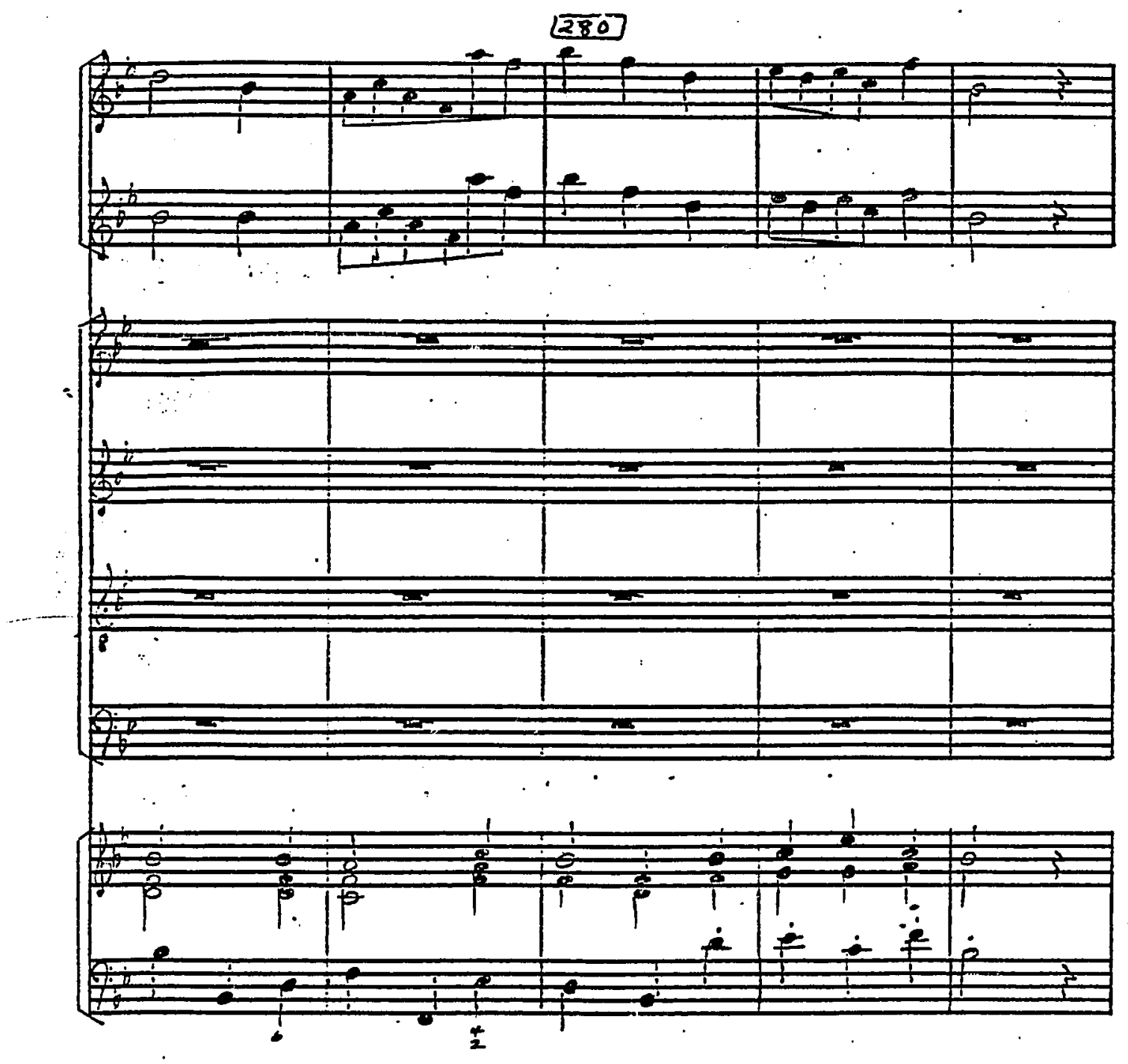




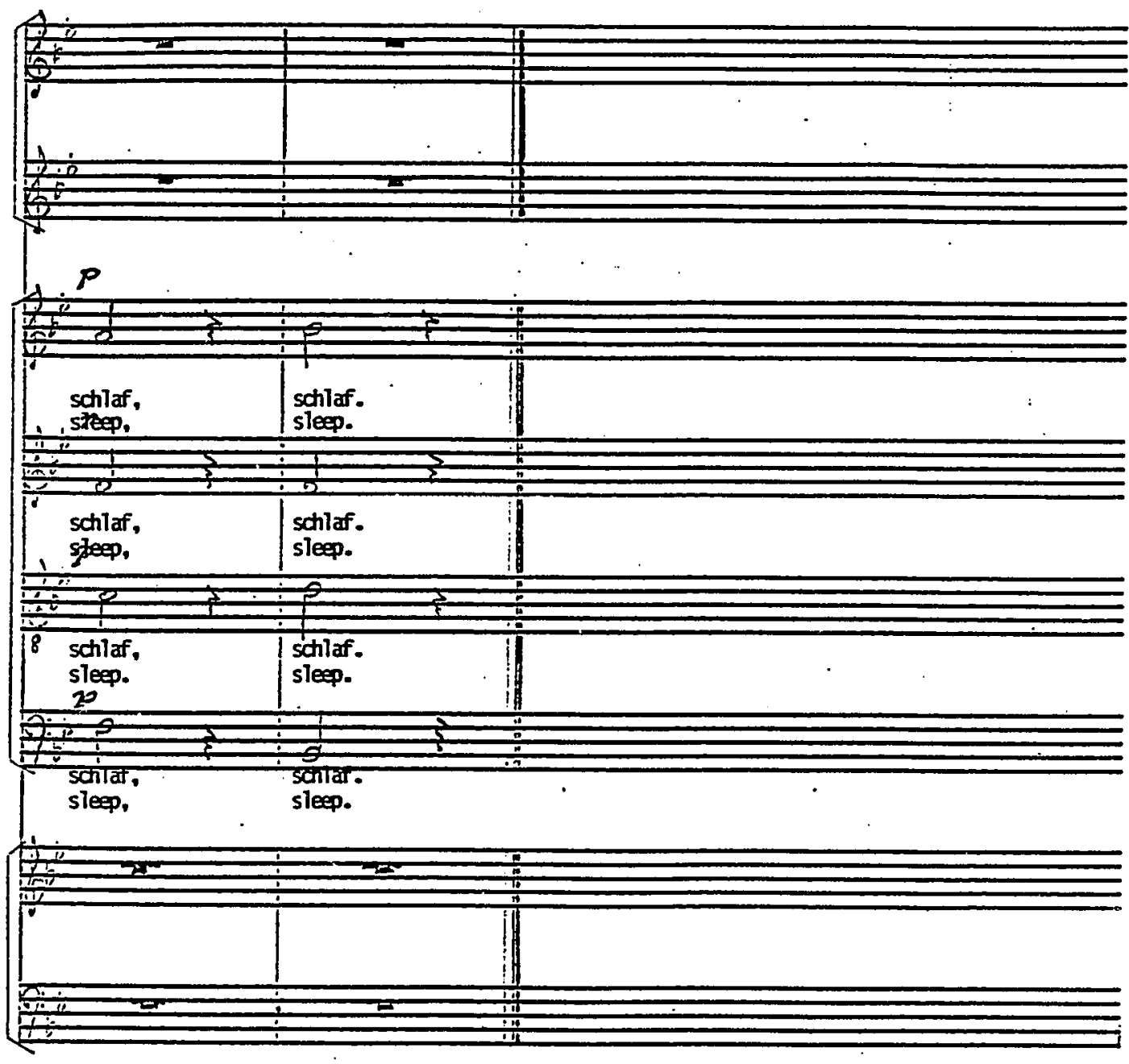




\section{APPENDIX B}

Available editions of Johann Michael Hayan's sacred choral music:

Agnus Dei *Easter, Agnus

(Hines) SATB LAWSON

(Hines) SATB LAWSON LG51823

Alleluia *Easter, anthen (Ehret, Walter) SATB, kbd (med) AUGSBURG 11-1921

Anima Nostra

[Lat] SSA, strings, cont sc, cor pts

HARMONIA 2523 f.s.

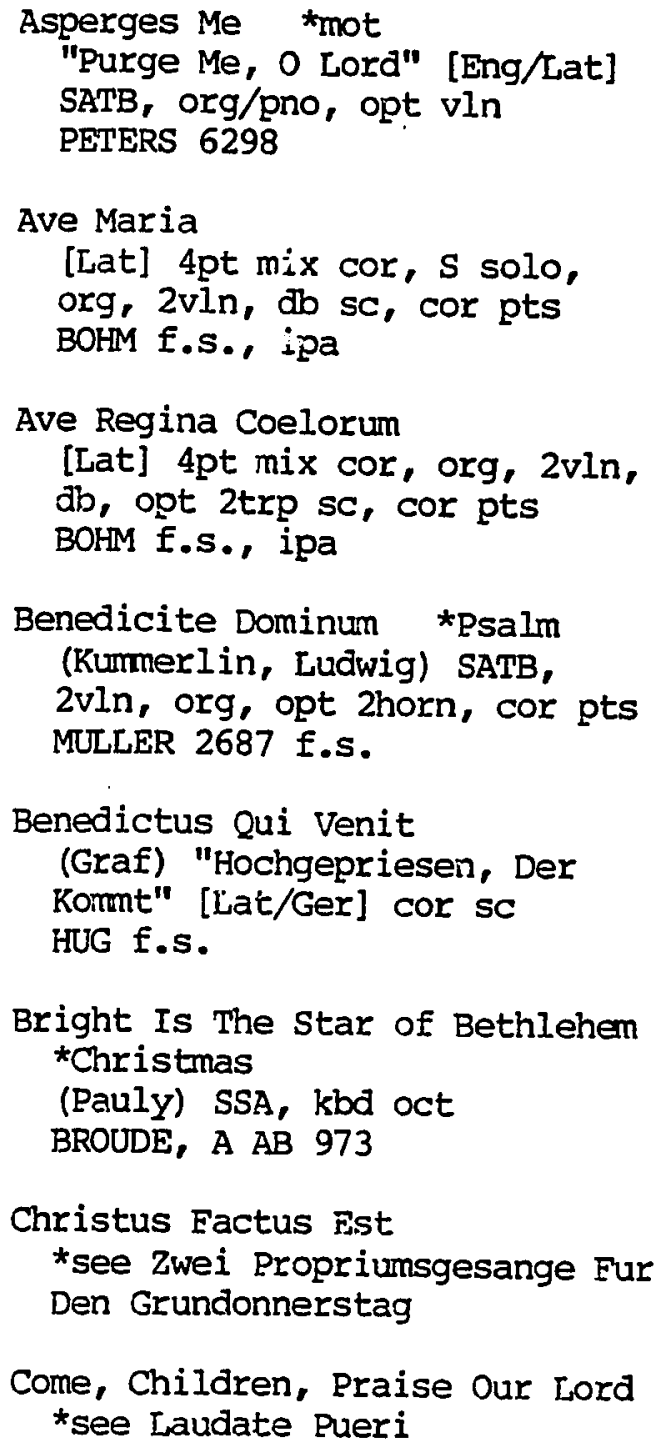

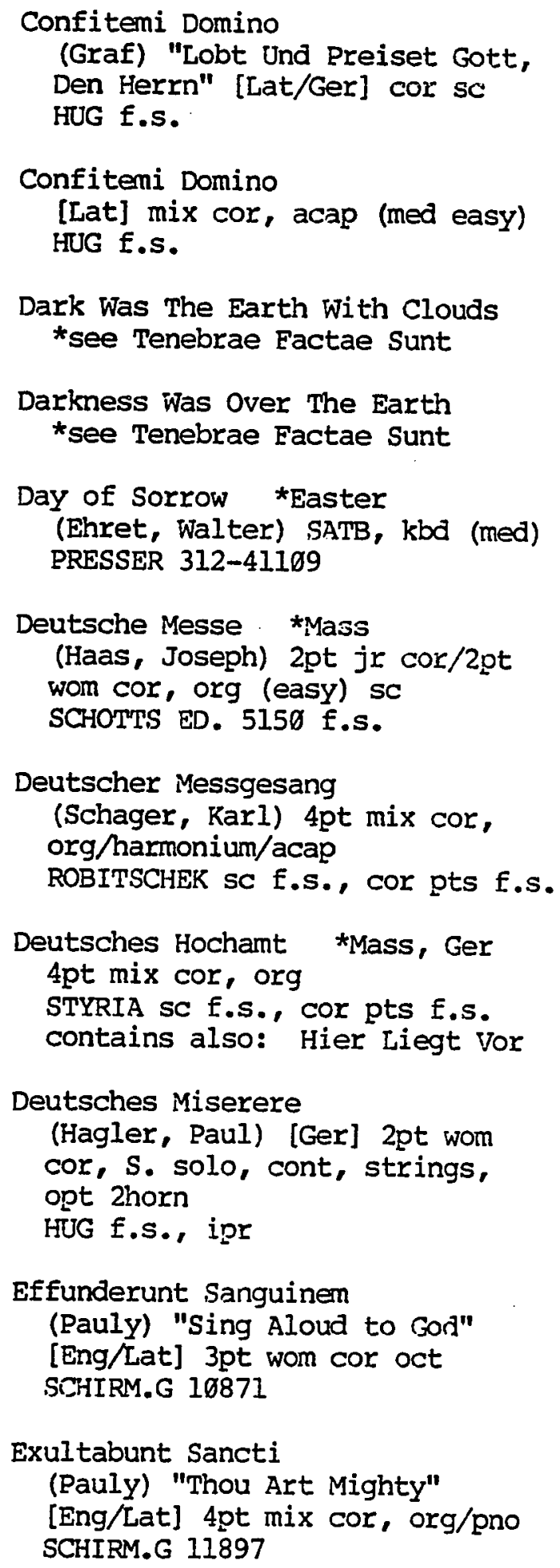


God, In Thee I Seek My Salvation (Pauly) [Eng/Lat] 4pt mix cor SCHIRM.G 10531

Great Is The Lord our Maker (Pauly) 4pt mix cor SCHIRM.G 16529

Heiligste Nacht *Christmas [Ger] mix cor, acap (easy) HUG E.s.

Herr, Grosser Gott, Dich Loben Wir *Fest. Te Deum [Ger] mix cor, org, 2trp sc, cor pts BOHM f.s., ipa

Hier Liegt Vor *see Deutsches Hochamt

Hier Liegt Vor Deiner Majestat 2pt wom cor, soli, 2horn, db, org DOBLINGER sc f.s., cor pts f.s., ipa

Himmel Erzahlen Die Ehre Gottes, Die 4pt mix cor, pno ROBITSCHEK SC f.S., cor pts f.s.

Hochgepriesen, Der Kormt *see Benedictus Qui Venit

Holy, Holy, Holy (from Missa Sub Titulo)

(Ehret, Walter) [Eng/Lat] SSA, pno/org (easy)

ELKAN-V 362-б3195

Hymne An Gott men cor, acap TONOS 6331 f.s.

In Monte Oliveti (Hilton, Arthur) "On Mount of Olives" [Eng/Lat] SATB, opt org MERCURY 352- 90467

In The Darkness of Night *see Tenebrae Factae Sunt
Jesu Redemptor omnium

[Lat] 4pt mix cor, acap sc, cor pts

BOHM f.s.

\section{Kreuzmesse *see Missa Sanctae Crucis In A-Moll}

Lamb of God *see Missa Sancti Aloysii: Agnus Dei

Lamb of God *see Missa Tempore Quadragesimae: Agnus Dei

Laudate Populi *Thanks, Offer SATB, SATB soli, 2trp in D, timp, org, 2vln, vcl, db [8'] voc sc BREITKOPF-W A-695 ipa

(Biba, 0.) 4pt mix cor, org, 2trp, 2vln, db, timp sc BREITKOPF-W PB-4839 f.s., ipa, cor pts BREITROPF-W CHB-4805 f.s., VOC SC BREITKOPE-W EB-6655 f.s.

Laudate Pueri *Christmas/Fest [Lat] SAT/SAB, org, 2vln SC, cor pts

BOHM f.s., ipa

(Pauly) "Come, Children, Praise Our Lord" [Eng/Lat] 3pt wom cor SCHIRM.G 10765

Laudate Pueri Dominum (Sulyok, Imre) SSA, cont, strings (easy) SC BAREN. BA 6219 f.s., cor pts BAREN. f.s., ipa

Lauft, Ihr Hirten, Allzugleich *Christmas, cant "Run, Ye Shepherds, To The Light" mix cor, S solo, strings voc sc VOLK 139 f.s. (Johnson) "Run, Ye Shepherds, To The Light" [Eng] SATB, S solo, $\mathrm{kbd} /$ strings voc sc BROUDE, A CP 184, ipr PRESSER, 302-41194 


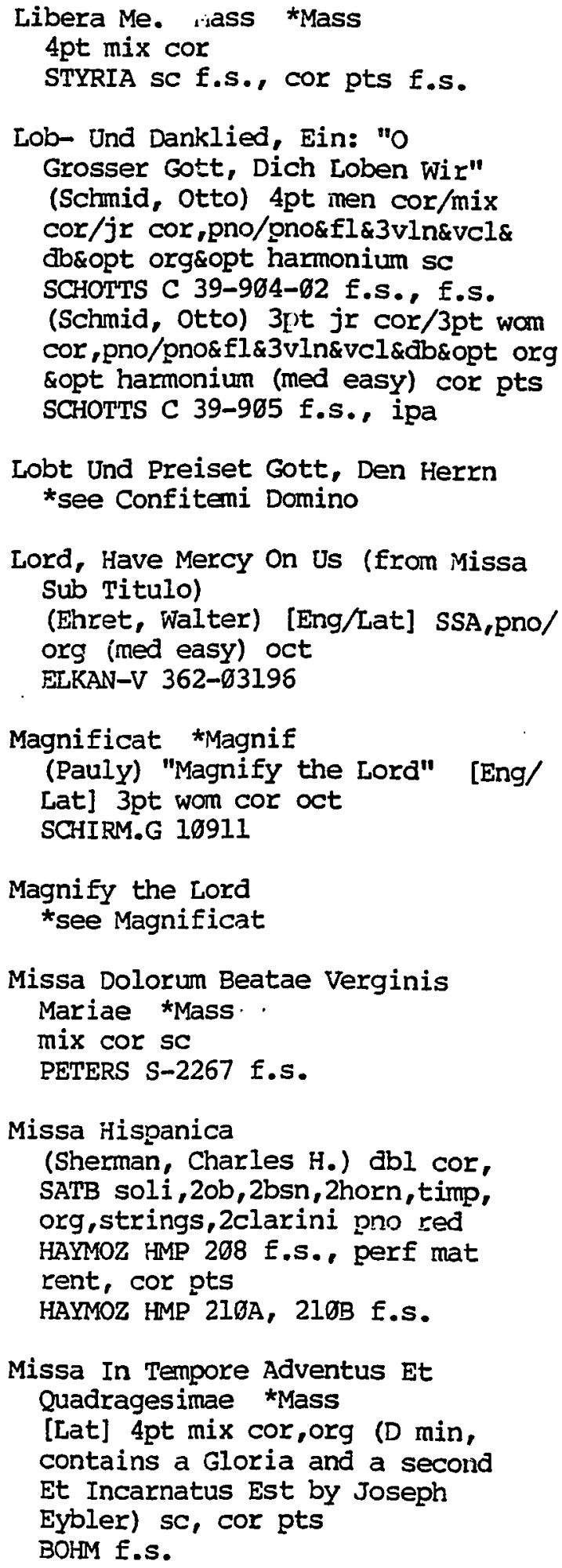

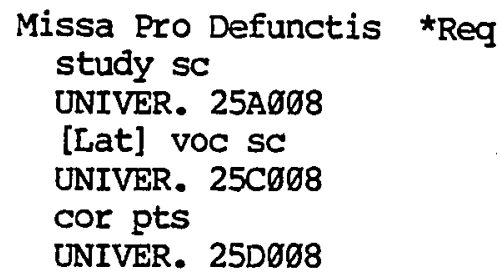

Missa St. Aloysii *Mass

cor, orch Sc

KAIMUS, ipa

Missa Sanctie Crucis in A-Moll *Mass

(Pfannhauser, K.) "Kreuzmess" 4pt mix cor, opt org (A min) DOBLINGER sc f.s., cor pts f.s. *sEe from OSTERREICHISCHE KIRCHENMUSIC

Missa St. Aloysii

*see Zwei Messen

Missa Sancti Aloysii: Pgnus Dei (Stockton, Robert) "Lamb of God" SSAA,pno

MUSIC SEV. M70-132

(Stockton, Robert) "Lamb of God" SSA,pno

MUSIC SEV. M70-132

Missa Sancti Hieronymi *Mass [Lat] voc sc UNIVER. 25Cøø7

cor pts

UNIVER. 25Døø7

study sc

UNIVER. 25Aø67

(Sherman, Charles H; Flothuis, Marius) $\operatorname{mix}$ cor, soli, 2ob, 2bsn, 3trom, org, db, 2ob soli sc UNIVER. UE 25Aøø7 f.s., perf mat rent, pno red UNIVER. UE 25C 007 f.s., cor pts UNIVER. UE 25Dø67 f.s. 


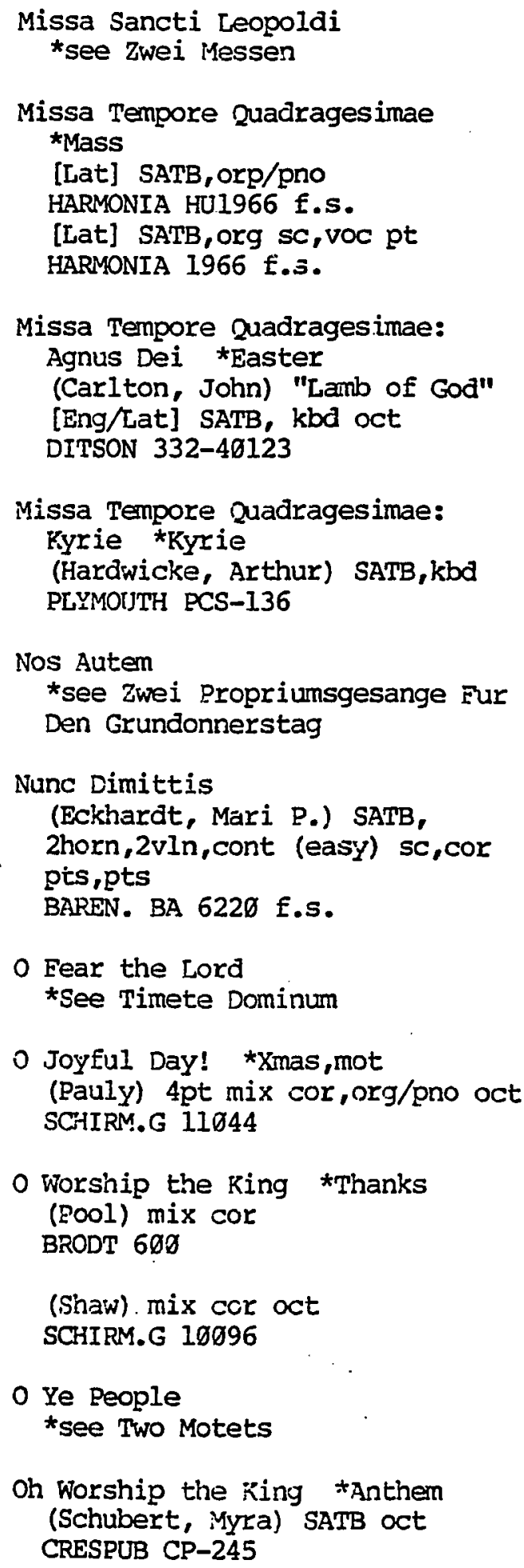

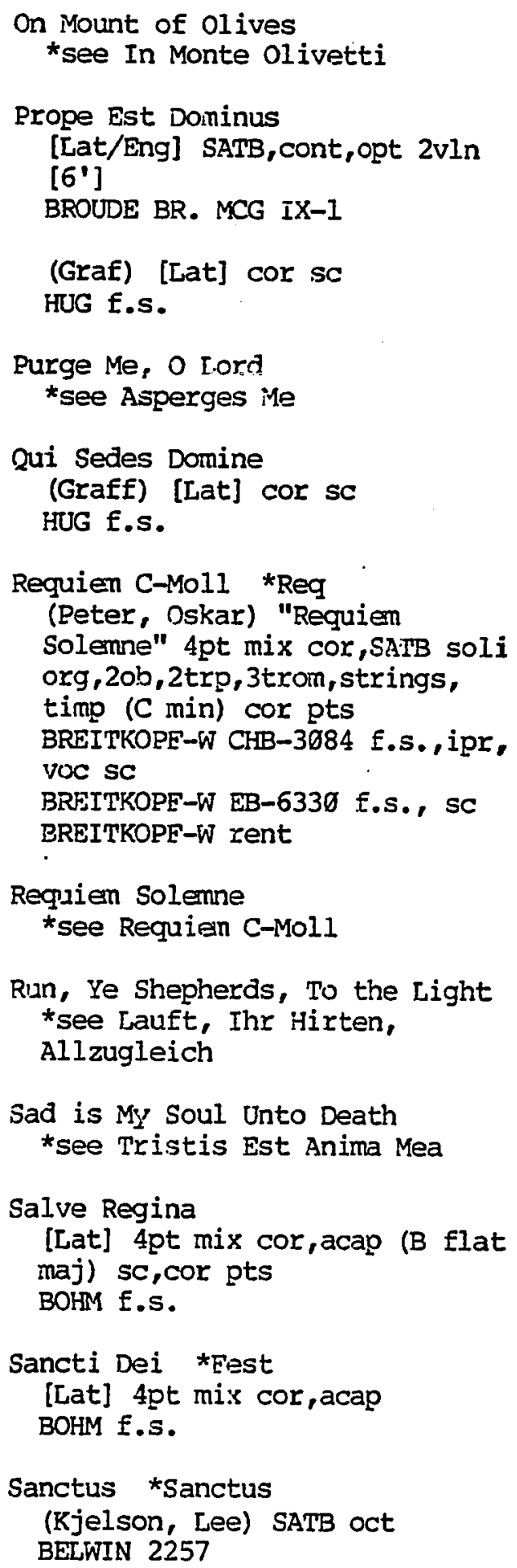




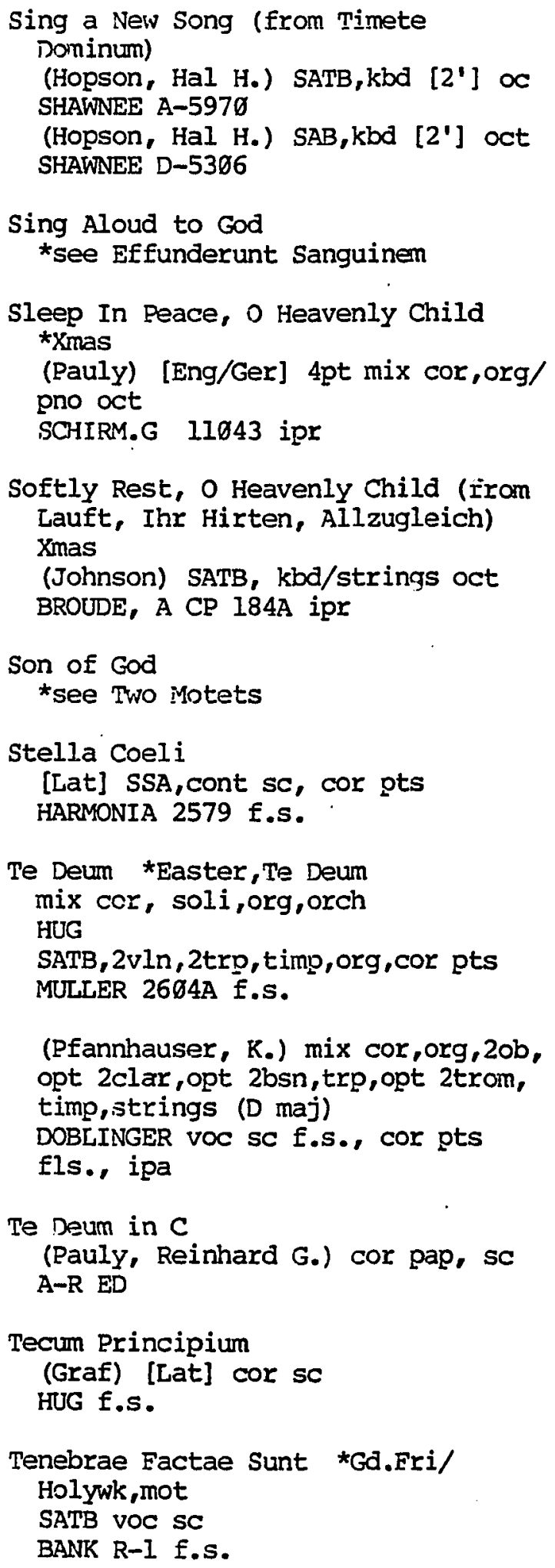

Tenebrae Factae Sunt cont...

[Lat] SATB

EGTVED MS8Bø2 f.s.

[Lat] SATB

RICORDI-ENG SYII6 f.s.

Cor A Coeur Joie 524 f.s.

4pt mix cor, acap

SCHOLA f.S.

"Dark Was the Earth With Clouds"

SATB,acap (Maundy Thursday)

SCHIRM.EC 1691

"Darkness Was Over the Earth" [Eng/Lat] SATB opt org/pno

- PETERS 6377

(Moulin) 4pt mix cor, acap SCHOLA f.s. contains also: Guillemain, Louis Gabriel, 0 Ma Souveraine

(Ramsey, W.) SATB oct BOONIN 148

(Ramsey, William) "In the-_. Darkness of Night" [Eng/Lat] SATB, acap [3'] oct EUR.AM.MUS EA 148

Tenebrae Factae Sunt *Holywk [Lat] 4pt mix cor,acap (E flat maj)

BOHM f.s.

Tenebrae Eactae Sung [Lat] 4pt mix cor,acap sc, cor pts BOHM f.s.

Thou Art Mighty *see Exultabunt Sancti

Timete Dominum *Mot (Pauly, Reinhard G.) "O Fear the Lord" [Eng/Lat] mix cor, soli, org, voc sc SCHIRM.G 2589

Tristis Est Anima Mea *Easter/ Lent

A COEUR JOIE 523 f.s. cor 
Tristis Est Anima Mea cont... (Marshall, Charles) "Sad is MY Soul Unto Death" SATB

FRANK F-577

Two Motets *Lent, mot (Pauly) [Eng/Lat] 4pt mix cor, acap, opt org/pno oct SCHIRM.G 11465 contains: O Ye People; Son of God

Universi Qui Te Expectant (Graf) [Lat] cor sc HUG f.s.

Veni, Sancte Spiritus (Graf) [Lat] cor sc HUG f.s.

Victimae Paschali *Easter (Biber, Otto) [Lat] SATB, strings, cont/org sc,cor pts HARMONIA 2345 f.s.

\author{
Viderunt onnes \\ (Biber, Otto) [Lat] SATB, \\ strings, 2ob, 2horn, org sc, cor \\ pts \\ HARMONIA 2407 f.s.
Zwei Messen tMass (Reinhart, Walter) [Lat] \\ HUG f.s. \\ contains: Missa Sancti Aloysii \\ (SSA/3pt wom cor/3pt boy cor, \\ SSA soli, org, $2 \mathrm{vln}, \mathrm{vcl} / \mathrm{db})$; \\ Missa Sancti Leopoldi \\ (SSA\&boy cor/wom cor,SSA soli, \\ org, 2 horn, $2 v 1 n, v c l / d b$ ) \\ Zwei Propriumsgesange Fur Den \\ Grundonnerstag *Holywk \\ [Lat\} 4pt mix cor, acap sc,cor \\ pts \\ BOHM f.s. \\ contains: Christus Factus Est; \\ Nos Auten
}

